\title{
SB 413
}

P4 B3

\section{Copy 2}



(1) (n) Q

Ond (2)

$\cos _{0 \rightarrow 0}$

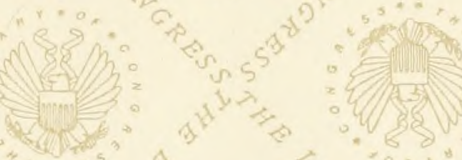

की

(1)

(n)

?

(1)

से

and

is

in

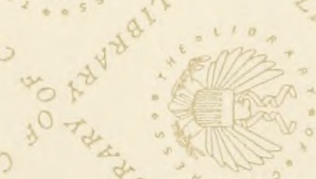






\section{SBA 13 .$P 43_{3}$ CORNELL UNIVERSITY copy?} AGRICULTURAL EXPERIMENT STATION OF

THE COLLEGE OF AGRICULTURE

Department of Horticulture

\section{CLASSIFICATION OF THE PEONY}

Fourth Report

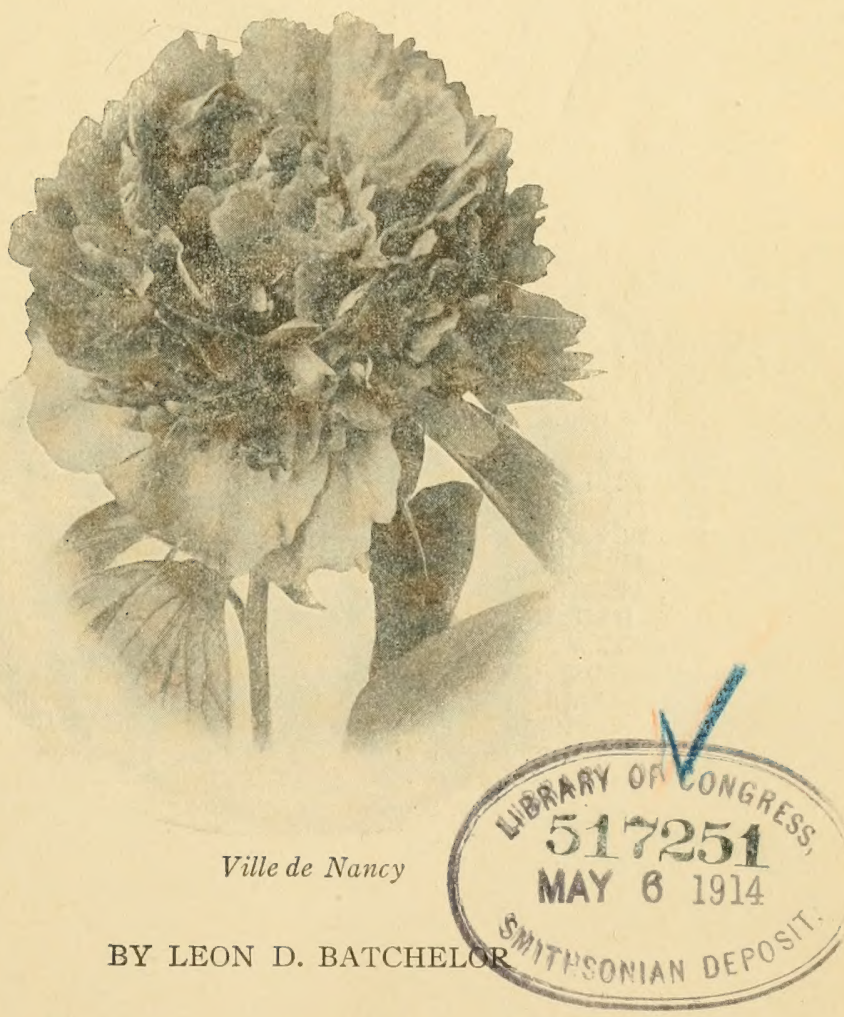

ITHACA, N. Y.

PUBLISHED BY THE UNIVERSITY 


\title{
CORNELL UNIVERSITY AGRICULTURAL EXPERIMENT STATION
}

\section{EXPERIMENTING STAFF}

\author{
LIBERTY H. BAILEY, M.S., LL.D., Director. \\ ALBERT R. MANN, B.S.A., Secretary. \\ JOHN H. COMSTOCK, B.S., Entomology. \\ HENRY H. WING, M.S. in Agr., Animal Husbandry. \\ JOHN CRAIG, M.S. in Agr., Horticulture. \\ T. LYTTLETON LYON, Ph.D., Soil Technology. \\ HERBERT J. WEBBER, M.A., Ph.D., Plant-Breeding. \\ JOHN L. STONE, B. Agr., Farm Fractice and Farm Crops. \\ JAMES E. RICE, B.S.A., Poultry Husbandry. \\ BEntAMin M. DUGGaR, M.S., Ph.D., Plant Physiology. \\ GEORGE W. CAVANAUGH, B.S., Chemistry. \\ HERBERT H. WHETZEL, A.B., M.A., Plant Pathology. \\ ELMER O. FIPPIN, B.S.A., Soil Technology. \\ GEORGE F. WARREN, Ph.D., Farm Management. \\ WILLIAM A. STOCKING, JR., M.S.A., Dairy Industry. \\ CHARLES S. WILSON, A.B., M.S.A., Pomology. \\ HARRY H. LOVE, Ph.D., Plant-Breeding Investigations, \\ ARTHUR W. GILBERT, Ph.D., Plant-Breeding. \\ DONALD REDDICK, A.B., Ph.D., Plant Pathology. \\ WILLIAM A. RILEY, Ph.D., Entomology. \\ MERRITT W. HARPER, M.S., Animal Husbandry. \\ J. A. BIZZELL, Ph.D., Soil Technology. \\ CLARENCE A. ROGERS, M.S.A., Poultry Husbandry. \\ GLENN W. HERRICK, B.S.A., Economic Entomology. \\ HOWARD W. RILEY, M.E., Farm Mechanics. \\ CYRUS R. CROSBY, A.B., Entomological Investigations. \\ HAROLD E. ROSS, M.S.A., Dairy Industry. \\ Elmer S. SAVAGE, M.S.A., Ph.D., Animal Husbandry. \\ LEWIS KNUDSON, B.S.A., Ph.D., Plant Physiology. \\ KENNETH C. LIVERMORE, B.S. in Agr., Farm Management. \\ ALVIN C. BEAL, Ph.D., Floriculture. \\ MORTIER F. BARRUS, A.B., Plant Pathology. \\ C. C. HEDGES, A.B., Agricultural Chemistry. \\ GEORGE W. TAILBY, JR., B.S.A., Superintendent of Live Stock, \\ EDWARD S. GUTHRIE, M.S. in Agr., Dairy Industry. \\ PAUL WORK, B.S., A.B., Olericulture. \\ EDWARD R. MINNS, B.S.A., Farm Practice and Farm Crops. \\ LEE B. COOK, M.S. in Agr., Dairy Industry. \\ MORRIS M. McCOOL, M.S. in Agr., Ph.D., Plant Physiology. \\ HARVEY L. AYRES, Superintendent of Dairy Manufactures. \\ CLARA NIXON, Assistant in Poultry Husbandry. \\ LOIS W. WING, A.M., Dairy Industry. \\ EMMONS W. LELAND, B.S.A., Soil Technology. \\ CHARLES T. GREGORY, B.S. in Agr., Plant Pathology. \\ WALTER W. FISK, B.S. in Agr., Dairy Industry,
}

The regular bulletins of the Station are sent free to persons residing in New York State who request them. 


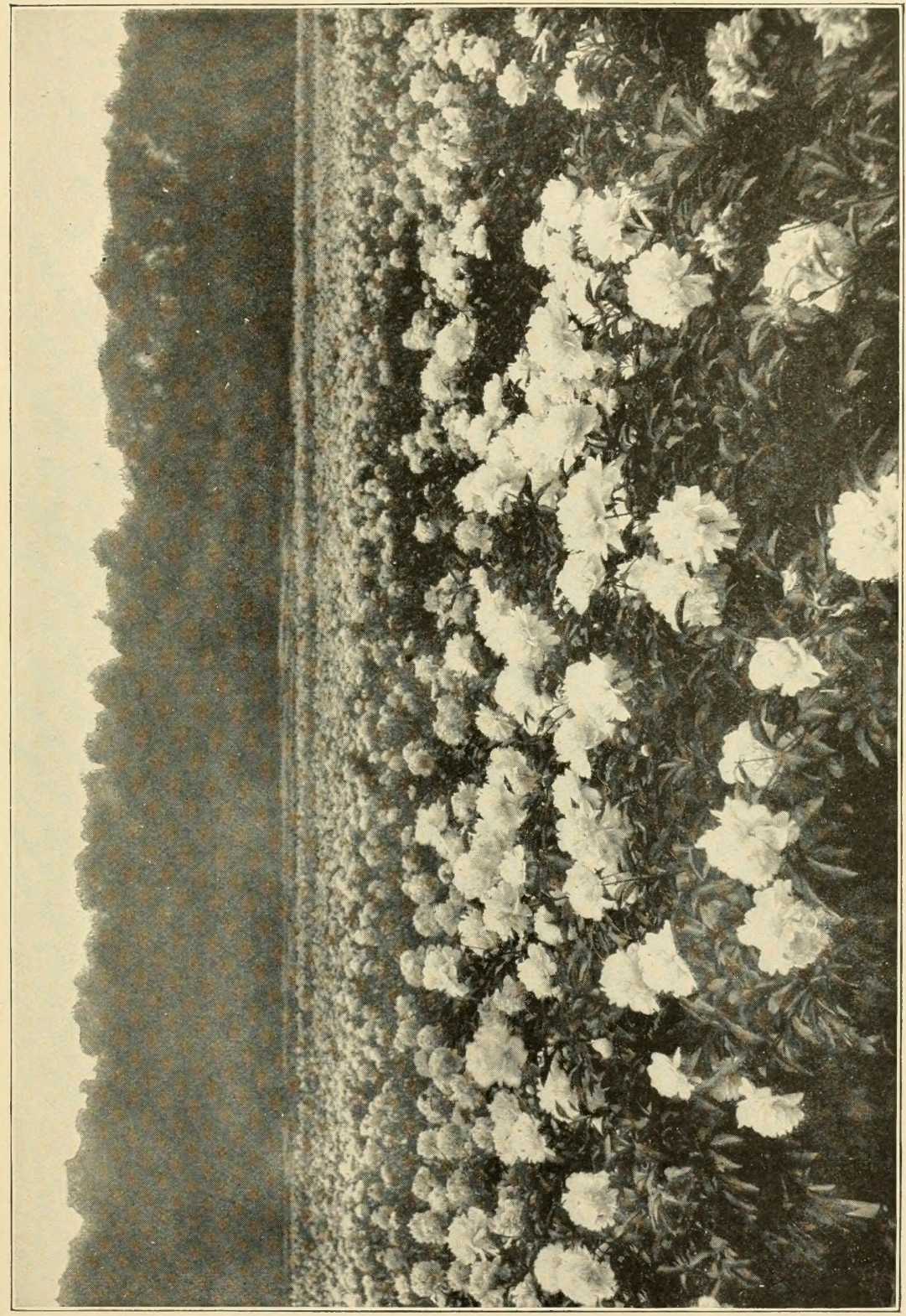

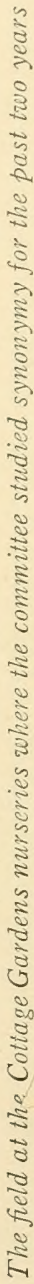





\section{INTRODUCTORY NOTE}

As chairman of the committee on nomenclature of the American Feony Society and also the person in general charge of the cooperative peony studies at Cornell undertaken by the Society and the Department of Horticulture, the writer is pleased to present to peony lovers a fourth report on the progress of this investigation.

This report, like the last published in Nay, I9IO, and reprinted through the financial aid of an interested amateur peony grower, is the work of Mr. Leon D. Batchelor, now professor of horticulture in Utah State Agricultural College, assisted as before by Messrs. Farr and Dauphin. While the field work involves technical skill and discriminating ability of a high order, the work of classifying and editing the field notes is also very considerable. In this as well as in the field work, Mr. Batchelor has rendered excellent service. Such asistance as he has received has been gratefully acknowledged. The whole study has been truly cooperative. It is now approaching the final stages when the important question of climinating large numbers of mediocre varieties should receive the thoughtful consideration of the Society. Another important step should be the establishment of a registry board to pass upon the merits of new varicties before these are officially recognized. Such a step would do much toward suppressing the introduction of many kinds of little or no value except in the eyes of the originator.

John Craig. 


\section{CONTENTS}

Introductory Note .......................... 53

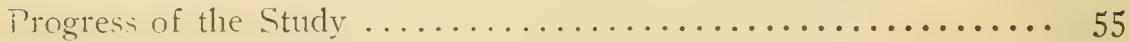

Well Recommended Varieties of Peonies............. 57

Additional Notes and Corrections to Descriptions in Bulletin $278 \ldots 59$

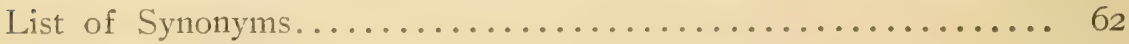

Description of Varieties.......................... 69

Index to Variety Descriptions .................... I55 


\title{
CLASSIFICATION OF THE PEONY
}

\author{
LEON D. BATCHELOR
}

\section{PROGRESS OF THE STUDY}

During the season of 1910 the work of peony classification was continued as outlined in liulletin 258 . Many additional varieties were identified, and a large number of synonyms were established.

There are still a few prominent varieties missing from this classification which could not be found in the nurseries visited and which do not occur in the Cornell trial plots. The classification at present, however, contains at least ninety-five pet cent of the important commercial varieties.

The commercial collections, which were started in the fall of Iyo7, produced an abundance of typical blooms the past season. The entire plot was carefully gone over and each firm's collections checked up as rcgards identity of varieties, synonyms, etc.

At the end of the season a report was sent to each donator stating the findings of the committee.

Studies were also made in the nurseries of several firms in the eastern part of the country.

It was the intention of the writer and Professor Craig to draw up an identification key to this entire classification. During the rusl of the blooming season, however, it was impossible to construct such a key and at the same time inspect the vast number of varicties necessary to conplete the classification and synonym list. It was found impracticalble to construct such a key after the bloming season was over by the descriptions alone, without the aid of the blooms themselves for comparison. In fact, the peony is so variable under different conditions, that the practicability of the identification key may itself be questionable. It should be thoroughly tricd out before any key is incorporated in the final report.

During the entire work the writer has been impressed with the large number of only medium varieties which are being continually originated and propagated by the trade. It is probably a conservative statement to say that the peony interests of the country would be better off if about seventy-five per cent of the varieties were destroyed and future propagation made from the remaining twenty-five per cent of superior varieties. It is not that these seventy-five per cent of the varieties are posi- 
tively unattractive; far from it. But the remaining twenty-five per cent fill every purpose and have many more virtues than the only medium to inferior sorts. By discarding the mediocre or poor sorts and selling only the more desirable varieties the customers would be even more infatuated with this beautiful flower, and a more extensive and higher class trade would be built up, to the benefit of all concerned.

It would also seem highly desirable before a new variety is brought into the trade to have it shown at the American Peony Society's annual exhibit and passed upon by a standing cominittee of the society appointed for this purpose. If the new sort proves to be something exceptionally fine, the society's stamp of approval and commendation should be a valuable asset in the sale of the novelty. When a new variety is not at least equal if not stperior to the similar varieties in the trade, the originator could hardly expect the support of a society already overburdened with too many sorts.

Permanent plots have been started on the Experiment Station grounds for the culture of varieties of which the identity is reasonably certain. As other varieties are classified, or new ones appear in the trade from time to time, they should be added to this planting, that an authentic, complete, permanent collection may become established for the advancement of the peony interests of the country.

Throughout the entire season Mr. Jos. Dauphin and Mr. B. H. Farr were in almost constant consultation with the writer in identifying varieties and establishing synonyms. A great deal of credit is due these gentlemen for their tireless effort and hearty cooperation with the Experiment Station in conducting this work. In fact, if the writer had been denied the aid of Mr. Dauphin's vast knowledge of varieties, and Mr. Farr's constant interest and self-sacrificing spirit, the completion of the work would hardly have been possible.

Acknowledgment is also due the several members of the American Peony Society, who have so kindly cooperated in answering many questions concerning the identity of varieties. Prof. A. P. Saunders has very materially aided in the work by his valuable suggestions and accurate work in proofreading. The American Peony Society is also greatly indebted to Professor Craig for his constant interest and wise guidance in the conduct of this work. 


\title{
VARIETIES FOR CL'T FLOUERS AND L.NISSCAPE UR IBR- DER PLANTING
}

The committee has frequently been called upon by amateur growers to recommend varieties of peonies for different purposes. We therefore include the following list of very desirable sorts which include some of the most valuable varieties in the trade:

\section{WELL RECOMMENDED VARIETIES OF PEONIES}

White

Festiva Maxima

For Cut Flowers

Couronne d'Or

Duchesse de Nemours

Baroness Schroeder

Albâtre

Alba Sulfurea

Madame Crousse

Madame Calot

Madame de Vernéville

Boule de Neige

Avalanche

Duc de Wellington

For Cut Flowers

Achille

Albert Crousse

Dorchester

Floral Treasure

La Perle

Madame Lemoine

Marguerite Gérard

Marie d'Hour

Miss Salway

Mademoiselle Léonie Calot

Madame Emile Gallé

Venus

For Cut Flozvers

Gloire de Charles Gombault

La Tulipe

Jeanne d'Arc

\author{
For Landscape \\ Octavie Demay \\ Marie Jacquin \\ Baroness Schroeder \\ Albâtre \\ Duchesse de Nemours \\ Alice de Julvécourt \\ Madame de Vernéville \\ Festiva \\ Marie Lemoine \\ Couronne d'Or \\ Madame Bréon \\ La Rosière \\ Albiflora the Bride \\ Avalanche \\ Festiva Maxima
}

Pale Pink

Achille

Eugène Verdier

Eugénie Verdier

Dorchester

Floral Treasure

Marie d'Hour

Triomphe de l'Exposition de Lille

Venus

La Perle

Marie Crousse

James Kelway

\section{Pink and White}

Umbellata Rosea

Golden Harvest

Madame Costé

Madame de Vatry

Thérèse

Princess Beatrice

Beauté Française

Philomèle 


\section{Deep Pink}

For Cut Flowers

Madame Ducel

Lamartine

Monsieur Jules Elie

Livingstone

Monsieur Boucharlat ainé

Souvenir de l'Exposition Universelle

Madame Lebon

Général Bertrand

Modeste Guérin

Edulis Superba

Alexandre Dumas

Madame Muyssart

Kelway's Queen

For Cut Filowers

Félix Crousse

Louis Van Houtte

Henry Demay

Red

Madame Ducel

For Landscape

Livingstone

Monsieur Boucharlat ainé

Souvenir de l'Exposition Universelle

Madame Lebon

Général Bertrand

Modeste Guérin

Edulis Superba

Madame Muyssart

Alexandre Dumas

Modèle de Perfection

\section{Deep Red}

\section{For Cut Flowers}

Delachei

Prince de Talindyke*

Constant Devred

Nigricans

Madame Becquet

Pierre Dessert

Rubra Superba

\section{For Landscape}

Fulgida

Félix Crousse

Augustin d'Hour

Louis Van Houtte

De Candolle

Henry Demay

Dr. Caillot

* I think Prince de Talindyke should not be recommended. The variety has only a local existence, and is, I helieve, a miswriting of Prince de Salm Dvck or a kind that harl lost its name. The European lists contain 110 Prince de Talindyke, and we should find out what its right name is before recommending it.

\section{A. P. Saunders.}

While the origin of Prince le Talindyke is unknown, and it is possible it may exist under another name, it is a fact that no duplicate of it has been found in the Cornell plot, nor in any other collection visited by the Committee. In freedom of blonm. length of stem, and durability, when shipper it is not surpassed by any other dark crimson. In color and habit of growth, it differs from Prince de Salm Dyck.

B. H. Farr. 


\section{ADDITIONAL NOTES AND CORRECTIONS TO IDESCRIP- TIONS IN BULLETIN 278}

Gínćral Bertrand, page 23i. " Rosetta " should be added as a synonym of this variety.

La Coquettc, page 232. Should be spelled thus, rather than as noted in former bulletin.

Dclachci, page 233. "Emperor William" should be added as a synonym of this variety, and the name should be "1)elachei "initead of "Delache."

Monsicur Dupont, page 233. "Merveilleuse" should be added as a synonym of this variety.

Rubens, page 239. Should be classed as a medium variety rather than inferior.

Charles Gossclin, page 241. This is not a true synonym of "Anemoneflora rubra." The varieties were simply mixed in the plots.

Petite Rence, page 2.12. Under remarks: it is the opinion of the committee that "Hinodesekai" is not identical with the above sort.

Madame de Bollemont, page 243. Should be spelled thus, rather than as noted in above bulletin.

Armand Rousseau, page 243. Should be spelled thus, rather than as noted in above bulletin.

Edouard Andri, page 243. Correct to a medium variety, with good landscape qualities; medium bloomer, with a medium stem.

Thurlow's Double Red, page 244. This so-called variety seems to be identical with "Dr. Caillot" (Verdier).

Fulgida, page 245. "Brennus" should be added as a synonym of this variety.

Grandiflora Nivea Plena, page 248. Should be carly rather than midseason.

Lutca Plcnissima, page 249. "Victor Durufle" should be added as a synonym.

Duchesse de Nemours, page 249. "Diamond" should be added as a synonym.

Alexandre Dumas, page 252. Should be spelled thus, rather than as it occurs in the aforementioned publication. "Rosamond" should be added as a synonym.

Victoire Lemon, page 253. "Anna " and "Phrynnée" should be added as synonyms.

Philomile, page 254. "Miss Brice" should be added as a synonym. [The piants seen under the name "Miss Brice" are Philomèle: but it is not at all certain these were the same as the original Miss Brice, introduced loy Kelway as one of their seedlings, and it is very likely that the true Miss Brice will be found 
to be a distinct variety and not a synonym. This is an example of many similar cases in which a name may be mistakenly classed as a synonym, because the plant we found so labeled may not be correct. It is as if we should come across a pink peony labelled Festiva Maxima that was identical with Edulis Superba, and should conclude that Festiva Maxima was a synonym of Edulis Superba. B. H. Farr.]

Prolifera Tricolor, page 254. "Prolifera" should be added as a synonym.

Duc de Cases, page 256. "Comte de Cayes" should be added as a synonym, although very likely a mere error in spelling.

Edulis Superba, page 257. L'nder synonyms: information on the identity of "Sainfoin " and "Glorie de Douai " indicates that these sorts are distinct varieties, even though they were merely "Edulis Superba" falsely labeled in the Cornell plots. (See note on "Miss Brice.")

Baron James de Rothschild, 1rage 259. "Lord Roberts" should be addied as a synonym.

Camea Elcgans, page 202. Should read, originated by Calot.

Good variety rather than poor.

Strong variety rather than weak.

Medium varicty rather than dwarf.

Free rather than medium bloomer.

Princess Maud, page 263. Remarks-Very similar to "Duc de Wellington."

Dr. Bretonncau, (Verdier), page 263. The following so-called sorts should be added as synonyms: "Rosea Superba " (this also is oftener a synonym of "MIodeste Guérin"), "Rosea Plenissima Superba," "Nell Gwynn," "Marquis Ito," "Madame Modéste," "Active," "Fairy Oueen," " Isabella Karlitzky," " Lady Leonora," " Reevesiana," " Frina," and "Thisbé."

Duchesse d'Orleans, page 267. "Plena I ariegata" should be added as a synonym.

Decaisue, page 269. There is some doubt as to the identity of this variety.

André Lauries, page 27I. This variety should be known as "Fragrans," as it was introduced from China, in ISO5, by Sir Joseph Banks under the latter name. The following synonyms should be added: "American Beauty," "Edulis," "Edulis Fragrans," " Chinensis Rubra," "Fragrantissima," "Mons. Charles Leverue " (here a variety under the name Mons. Charles is meant, since the varicty Charles Leveque, introduced from IIolland, is a synnnym of Nille. Léonic Calot.- R. II. Farr), and "Rosea Plenissima."

Madam, Emile I.cmoinc, page 27.3. Added note: prominent carmine flecks occur on the central petals. 
Dr. Caillot, page 274. "Thurlow's Double Red " should be added as a synonym.

La Brunc, page 276. Should be described as loose semi-double rather than semi-rose type; in fact, it is nearly single in some cases.

Empercur Nicolas, page 278. Remarks - There is another " Emperor Nicolas" in the trade, of a dark purple garnet color 4 (I65).

Madcmoisclle Líonic Calot, page 280. " Monsieur Charles Leveque " should be added as a synonym. The latter variety has also occurred as a synonym of "André Lauries."

Delicatissima, page 284 .

Description in ditail - (ireen flecks and a cream white color are characteristics which freguently distinguish the blooms of this variety.

Remarks - "Delicatissima" usually blooms about two day's later than "Floral Treasure," has a more erect habit, has a small crown, and is a tint darker when closely compared with "Floral Treasure."

Globosa, page 286. Description in bricf should read: "Medium to large, fading to cream white."

Carnca Humci, page 287. Should be described as carly', rather than very late season. (The correct name is Humei Carnea.)

Lamartine, page 288. Should be classed a rose type bloom, uniform color throughout, rather than "guards and collar fading rose white." [There is another Lamartine. Introduced by Lemoine in 1908. Deep violet rose with wide silvery border. Very tall. Rose type.-B. H. Farr.]

"Gigantea" and "Habid" should be added as synonyms.

Livingston, page 289. "Adele" should be added as a synonym.

Maríchal I'aillant, page 293. "Lee's Grandiflora" should be added as a synonym.

Eugène Verdier, page 293. Should be described as very erect habit. Lafuycttc, page 294. Should be, originated by Dessert, I904. Description, rose bloom, silver tipped.

\section{INDEX TO VARIETY DESCRIPTION}

"Emma" should be added, page 257 .

"Madame Bréon" should be added, page 26 I.

\section{DESCRIPTION OF VARIETIES}

In the following descriptions the varieties of peonies are classified into eight groups: Single, Japanese, Anemone, Semi-doulble, Crown, Bomb, Semi-rose, and Rose. For a discussion of the above classification see Bulletin 278, page 227. 


\section{EXPLANATORY REMARKS}

A slightly different method of indexing has been used this year, in that the varieties are arranged alphabetically as they are commonly spolien of: whereas in previous publications, in case of the presence of a surname the variety was listed under this rather than the given name. This method has caused some confusion; however, as it was in use when the writer took up the work it was followed until this publication, when a more simple method was adopted. For example: Alba Sulfurea is found under " 1, , Georgiana Shaylor under " $(i$, "whereas they would formerly have been classified under "S."

The following index includes all varieties classified in Bulletins 259 and 278 as well as this pullication. The descriptions are made in a little more detail than previously, especially concerning the plant habit and general adaptability of the variety.

A discussion of the method of describing varieties and color comparisons will be found on pages 223-227 of Bulletin 278 .

The varicties which are described as blooming in clusters should be disbudded when grown for-cut blooms.

\section{LIST OF SYNONYMS}

\section{ACTIVE.}

This so-called variety is a synonym of "Dr. Bretonneau," originated by Verdier in 1854. "Active" appeared suddenly in the trade within recent years from an unknown source.

See "Dr. Bretonneau," Bulletin 278, page 263.

\section{ADELE.}

This so-called varicty, not found very widely in the trade, is a synonym of "Livingston," originated by Crousse, 1879. For a description see Bulletin 278, page 289 .

\section{ALBA MAXIMA.}

This is a synonym of the well known variety "Festiva Maxima," originated by Miellez in I85I. "Alba Maxima" has heen starterl on its masquerade since Igoo.

\section{AMERICAN BEAUTY.}

This so-called variety is a synonym of "Fragrans," introduced from China by Sir Joseph Banks in 1805 , since which it has masqueraded under many different names. See page 63.

\section{ANNA.}

This so-called variety which has come very recently into the trade is a synonym of "Victoire Lemon," originated by Miellez, 1858.

For description see Bulletin 278, page 253. 


\section{BRENNUS.}

This so-called variety is a synonym of "Fulgida," originated by Parmentier in I850. "Brennus" seems to have come into the trade from unknown sources within recent years. For a description of "Fulgida" see Bulletin 278, page 245.

\section{CHINENSIS RUBRA.}

This so-called variety is a synonym of "Fragrans," introduced from China by Sir Joseph Banks in I805, since which it has masqueraded under many different names. See below.

\section{COMTE DE CAYES.}

This so-called variety is a synonym of the well known varicty " Duc de Cazes," originated by Guerin in I850. "Comte de Cayes" started on its career from an American nursery within recent years.

\section{DIAMOND.}

This so-called variety, which has come into the trade since Igoo, is a synonym of "Duchesse de Nemours" (Calot 1856).

For a description see Bulletin 278, page 249.

\section{DUKE OF CLARENCE.}

This so-called variety seems to be a synonym of "Princess Beatrice," originated by Kelway in 1886 . See Bulletin 278 , page 250 .

\section{EDULIS.}

This so-called variety is a synonym of "Fragrans," introduced from China by Sir Joseph Banks in 1805 , since which it has masqueraded under many different names. See below.

\section{EDULIS FRAGRANS.}

This so-called variety is a synonym of "Fragrans," introduced from China by Sir Joseph Banks in 1805 , since which it has masqueraded under many different names. See below.

\section{EMPEROR WILLIAM.}

It is doubtful if there is a true variety of this name, as there is no record of any such being originated. As it has occurred in the Cornell plots it has been really "Louis Van Houtte" in one case and "Delachei" in the other.

\section{FAIRY QUEEN.}

This so-called variety was supposed to have been originated by Terry, but wherever it has been seen by the committee it has proved to be "Dr. Bretonneau" (Verdier).

\section{FRAGRANS.}

Correction to Bulletin 278 , page $27 \mathrm{I}$. The above varicty is wrongly described as "André Lauries" in the aforementioned publication. For a correct description of "André Lauries" see page 152. These two varieties have been somewhat confused, and "Fragrans" is more often sold as "André Lauries" than otherwise.

"Fragrans" was introduced from China by Sir Joseph Banks in I8o5, while "André Lauries"-was originated by Crousse in $188 \mathrm{r}$. 
Synonym - "Fragrans" is also found in the trade under the following names: "American Beauty," “Edulis," “Edulis Fragrans," “Chinensis Rubra," "Fragrantissima," "Monsieur Charles Leveque," and "Rosea Plenissima." These names should be stricken from the trade as they are synonyms of "Fragrans" pure and simple.

\section{FRAGRANTISSIMA.}

This so-called variety is a synonym of "Fragrans," introduced from China by Sir Joseph Banks in 1805 , since which it has masqueraded under many different names. See page 63 .

\section{FRINA.}

This so-called variety, which has recently appeared in the trade from Europeail nurseries, is a synonym of "Dr. Bretonneau" (Verdier).

For a description see Bulletin 278 , page 263.

\section{GALENE.}

Notc: Same as "Stewart's America."

\section{GIGANTEA.}

This so-called variety is a synonym of the well known variety "Lamartine," originated by Calot in 1860 . "Gigantea" has suddenly appeared in the trade from unknown sources since 1900.

"Dr. Bretonneau" (Verdier) has also been found masquerading under the name of "Gigantca."

\section{HABID.}

This so-called variety is a synonym of the well known variety "Lamartine," originated by Calot in I860. "Habid" has suddenly appeared in the trade from unknown sources since Igoo.

\section{ISABELLA KARLITZKY.}

"Dr. Bretonneau" (Verdier) often appears in the trade under the above name. The true variety is described in Bulletin 259, page 142.

\section{LADY LEONORA.}

This so-called variety is a synonym of "Dr. Bretonneau" (Verdier), "Lady Leonora Bramwell," etc.

See “Dr. Bretonneau," Bulletin 278, page 263.

\section{LEE'S GRANDIFLORA.}

This so-called varieıy is a synonym of "Maréchal Vaillant," originated by Calot in 186\%. "Lee's Grandiflora" came to public notice very recently.

\section{LORD ROBERTS.}

This so-called variety is a synonym of "Baron James de Rothschild," originated by Guerin in I850. "Lord Roberts" suddenly appeared in the trade from unknown sources about 1900 . 


\section{MADAME MODESTE.}

This so-called variety is a synumym of "Dr. Bretorneau," originated by Verdier in 1854 . "Madame Mudeste" appeared suddenly in the trade within recent years from an unknown source.

See "Dr. Bretonneau," Bulletin 278, page 263.

\section{MARIE STUART.}

A variety occurring in the Cornell plots under this name is identical with "Venus." There is a "Marie Stuart" (Calot), however, which is entirely unlike the above. See Bulletin $2 \% 8$, page 255 .

\section{MARQUIS D'LORY.}

This so-called variety is a synonym of "Virginie," originated by Calot in 1856 ; it began its masquerade as "Marquis d'Lory" since I9oo.

\section{MARQUIS ITO.}

This so-called variety is a synonym of "Dr. Bretonneau," originated by Verdier in 1854. "Marquis Ito" appeared suddenly in the trade within recent years from an unknown source.

See “Dr. Bretonneau," Bulletin 278, page 263.

\section{MERVEILLEUSE.}

This so-called variety, which has appcared in the trade since 1900 , has proved to be a synonym of "Monsieur Dupont," originated by Calot in 1872.

For a description see Bulletin 278, page 233.

\section{MISS BRICE.}

This so-called variety, which was supposed to have been originated by Kelway in I888, has proved to be "Philomèle," originated by Calot in I86I.

\section{MONSIEUR CHARLES LEVEQUE.}

This so-called varicty, sent to the Cornell plots from Europe, proved to be a synonym of "Mademoiselle Léonie Calot," originated by Calot in I86I.

\section{MONSIEUR DOFFREY.}

This so-called variety has come into the trade within recent years. Is a synonym of "Fragrans."

See "Fragrans," page 63.

\section{MRS. SAGUTE.}

This so-called variety of unknown origin is a synonym of "Madame Ducel," originated by Mechin in 1880. For a description see Bulletin 259, page 132.

\section{NELL GWYNN.}

This so-called variety is a synonym of "Dr. Bretonneau," originated by Verdier in I854. "Nell Gwynn" appeared suddenly in the trade within recent years from an unknown source.

See “Dr. Bretonneau" (Verdier), Bulletin 278, page 263 


\section{PAPILIONACEA.}

This so-called variety is identical with "Whitleyi" and should be known as such. "Whitleyi" was found in the trade as early as 1820 and was supposed to have been originated by Whitley in iscs; while "Papilionacea" has come forth since 1900. For a description of "Whitleyi" See page Io6.

\section{PEARL.}

This so-called variety has proved identical with "Venus."

\section{PERFECTION.}

(This is not Richardson's)

This so-called variety is a synonym of "Madame Courant," originated by Courant in 1850 .

For a description see page 80 .

\section{PHOENICA VARIEGATA.}

This so-called variety, which came into the trade from unknown sources since 1900 , is a synonym of "Madame Courant," originated by Courant in 1850 . For a description see page 80.

\section{PHRYNNÉE.}

This so-called variety scems to be a synonym of "Victoire Lemon," originated by Miellez, I858.

For a description, see Bulletin 278, page 253.

\section{PLENA VARIEGATA.}

This so-called varicty has appeared in the American trade within recent years; wherever it has been seen it has proved to be a synonym of "Duchesse d'Orleans."

lior a description see Bulletin 278, page 267.

\section{PRINCESS MAY.}

This so-called variety has proved identical with "Venus," which was in the trade about twelve years before it appeared as "Princess May."

\section{PROLIFERA.}

This is a synonym of, and should be known as, "Prolifera Tricolor," originated by Lemon in 1825. For a description of the variety see page 254, Bulletin 278.

\section{QUEEN ESTHER.}

This so-called variety is a synonym of "Madame Costé."

For a description see page rog.

\section{QUEEN VICTORIA.}

This well known variety has heen in the trade since $I 830$ and everywhere it has appeared it has proved identical with "Whitleyi," another well known sort originated lyy Whitley in I Sos. It should be known only as "Whitleyi," and "Queen Victoria" and its many other synonyms stricken from the trade lists. For a description of "Whitleyi" see page Io6.

Note: There is, however, a variety "Queen Victoria" originated by Kelway within recent years. See page 93. 


\section{REEVESIANA.}

If there is a genuine variety by this name, it is not known to the committce. Wherever it has been seen by the committec it has proved to be "Dr. Bretonneau" (Verdier).

\section{ROSA BARRY.}

This so-called varicty, which was supposed to have originated in Ellwanger \& Barry's nurseries, has proved to be "Whitleyi."

For a description of "Whitleyi" see page 106.

\section{ROSAMOND.}

It is very doubtful if there is a true variety of peony by this name. Wherever it has been seen it has been a synonym of "Alexandre Dumas."

For a description see Bulletin 278, page 252.

\section{ROSEA PLENISSIMA.}

This so-called variety is a synonym of "Fragrans." introduced from China by Sir Joseph Banks in ISO5, since which it has masquerated under many different names. See page 63 .

\section{ROSEA PLENISSIMA SUPERBA.}

This so-called varicty is a synonym of "Dr. Bretonneau," originated by Verdier in 1854. "Rosea Plenissima Superba" appeared suddenly in the trade within recent years from an unknown source.

See "Dr. Bretonneau" (Verdier), Bulletin 278, page 263.

\section{ROSEA SUPERBA.}

This so-called variety is a synonym of "Dr. Bretonneau," orıginated by Verdier in 1854. "Rosea Superba" appeared suddenly in the trade within recent years from an unknown source.

See "Dr. Bretonneau" (Verdier), Bulletin 278, page 263.

Note: The above should not be confused with "Dr. Bretonneau," originated by Guerin in 1850 . See Bulletin 278, page 280 .

"Modeste Guérin" has also been found under the assumed name of "Rosea Superba."

\section{ROSETTA.}

This so-called variety appeared in the American trade within recent years. It is, however, a synonym of "Général Bertrand," originated by Guerin in 1845 .

For a description see Bulletin 278, page 231.

\section{SNOW WHITE.}

This is a synonym of, and should be known as, "Whitleyi," one of the oldest peonies in the trade. "Snow White" began its masquerade within recent years.

For a description of "Whitleyi" see page Ic6.

\section{STEWART'S AMERICA.}

This so-called variety is one of the many synonyms for "Whitleyi," which has been in the trade since I808. "Stewart's America" appeared in the trade from unknown sources within recent years.

Correclion to Bulletin 259. The above was described as a true variety in the aforementioned publication before it was known to be a synonym of "Whitleyi." 


\section{THISBÉ.}

This so-called variety, which has been catalogued by both American and European growers, has proved to be "Dr. Bretonneau" (Verdier). "Thisbé" should be stricken from the trade, with the several other synonyms of this well known sort.

For a description of "Dr. Bretonneau" (Verdier) see Bulletin 278, page 263.

\section{THURLOW'S DOUBLE RED.}

Although this variety was supposed to have originated in Mr. T. C. Thurlow's nursery, it seems identical with "Dr. Caillot," originated by Verdier in 1856. The committee is of the opinion that it can safely be considered a synonym of "Dr. Caillot."

Note: The plants on which judgment was passed were sent to the Cornell plots by $\mathrm{Mr}$. Thurlow in 1907 .

Correction to Bullctin 278. The above was described in this publication before it was known to be a synonym.

\section{TRIUMPHANS GANDAVENSIS.}

Synonym - This so-called variety is, without doubt, "Alice de Julvécourt" and should be known as such. "Alice de Julvécourt" was originated by Pele in 1857, while Triumphans Gandavensis suddenly appeared from unknown sources a few years later. For "Alice de Julvécourt" see page 103.

Correction to Bullctin 259. This sort was wrongly described under the above name in Bulletin 259 before it was known to be a synonym.

\section{VICTOR DURUFLE.}

It is very doubtful if there is a true variety by this name; wherever it has been observed, it has proved to be identical with "Lutea Plenissima," and should therefore be known only as a synonym of this well known variety. For a description of "Lutea Plenissima" see Bulletin 278, page 249.

\section{ADDITIONAL SYNONYMS}

Noted in Bulletin 278

\begin{tabular}{|c|c|}
\hline PAGE & PAGE \\
\hline Acanum & Lemoine.. \\
\hline Bridesmaid . .. & Lilacina Superba .............. 258 \\
\hline Canista . . ................. 265 & Maiden's Blush . . . ......... 254 \\
\hline Cyntherii . . .............. 247 & Mamie Cutler . . ............ 256 \\
\hline Delia . . ................. 256 & Mons. Andre . . . . . . . \\
\hline Early Rose . . ............. 256 & Pizano....... \\
\hline Edulis Odorata . . ........... 256 & Rosa Lilacina . . . \\
\hline Emma . . ............... 257 & Sailet \\
\hline Glorie de Deumai ............ 258 & 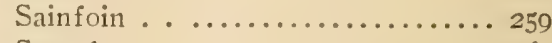 \\
\hline Grandiflora Alba Laciniata ...... 248 & Superba . . .............. \\
\hline Gretchen . . . . . . . . . . . . 253 & Sylvanus ...................260 \\
\hline Hector . . ................ 258 & Thorbeckii . . .............. 292 \\
\hline Jussier . . ................ 245 & Water Lily . . .............. 242 \\
\hline
\end{tabular}




\section{DESCRIPTION OF VARIETIES}

SINGLE TYPE

\section{White}

\section{COUNTESS OF WARWICK.}

Species - P. albifiora.

Originated by Kelway.

Donated by Farr.

Description of bloom - Type of bloom single. Color (total effect) 2 (7) lilac white. Fragrance unpleasant X. Blooming time early. Very large size.

Description of plant - Habit of plant erect, medium tall, compact. Growth strong and healthy. Stem medium long, very strong, green to reddish green. Blooming habit medium. Buds borne in clusters. Foliage well furnished, medium to light green, medium size; veins green.

Commercial value - For cut bloom poor; landscape value good.

Remarks-Similar to "Flag of Truce" but heavier stem, slightly taller, coarser foliage, and more open bloom. "The Queen" has a lighter foliage and is slightly more double.

\section{FLAG OF TRUCE.}

Species - P. albiflora.

Originated by Kelway.

Donated by Farr.

Description of bloom - Type of bloom single. Color (total effect) lilac white 3-4 (7); guards clear. Fragrance unpleasant XX. Blooming time early. Large size.

Description of plant - Habit of plant erect, medium to divarf, compact. Growth strong and healthy. Stem medium long, strong, green. Blooming habit very free. Buds borne in clusters, healthy. Foliage well furnished, medium green, medium size; veins green.

Commorcial zaiue - Landscape value extra good single. Variety as a whole extra good.

Kemarks - This is a better bloomer than "Countess of Warwick."

\section{THE QUEEN.}

Species- P. albiflora.

Originated by Kelway.

Donated by Farr.

Description of bloom - Type of bloom single. Color (total effect) lilac white I

( 7 ) : guards slightly splashed. Very desirable, single white bloom. Fragrance unpleasant XX. Blooming time early. Large size.

Description of plant - Habit of plant erect, medium to tall, compact. Growth strong and healthy. Stem medium long, strong, green to reddish green. Blooming habit free. Buds borne in clusters, healthy. Foliage well furnished, medium to light green, medium size; veins green.

Commcrial z'alue - For cut bloom poor; landscape value extra good. Variety as a whole good.

\section{DOROTHY.}

Pink

Species - P. albiflora.

Originated by Kelway.

Donated by Thurlow.

Description of bloom - Type of bloom single. Form of bloom flat. Color (total effect) violet rose 4 (I 45$)$; guards clear. Single row of guards, smooth car- 
pels, red stigmas. Fragrance unpleasant XX. Blooming time mid-season. Size medium to large.

Description of plant-Habit of plant erect, medium height, compact. Growth strong and healthy. Stem medium long, medium strong, green. Blooming habit free. Buds borne in clusters, healthy. Foliage very well furnished, medium to light green, coarse; veins green.

Conmercial zalue - For cut bloom poor; landscape value medium. Variety as a whole medium.

\section{EMILY.}

Species - P. albiflora.

Originated by Kelway.

Donated by Farr.

Description of bloom - Type of bloom single. Form of bloom globular. Color (total effect) violet rose I (I54). Double row of petals. Bloom does not open up wide. Fragrance unpleasant XX. Blooming time extra early. Medium size.

Description of plant-Habit of plant erect, medium to tall, medium compact. Growth strong and healthy. Stem medium to long, strong, red. Blooming habit free. Buds borne in clusters, healthy. Foliage medium furnished, medium green, medium size; veins red.

Commorcial zalue - For cut bloom poor; landscape value medium. Variety as a whole medium.

Remarks - Not an especially clear, desirable color.

\section{LEUCADIA.}

Specics - P. albiflora.

Donatcd by Thurlow.

Originated by Kelway.

Discription of bloom - Type of bloom single. Form of bloom flat. Color (total effect) solferino red 2 (I57); guards clear; carpels green; smooth, white stigmas; collar petals silver tipped. Fragrance unpleasant X. Blooming time mid-season. Large size.

Description of plant - Habit of plant erect, tall, medium compact. Growth strong and healthy. Stem long, strong, green. Blooming habit free. Buds borne in clusters, healthy. Foliage medium furnished, light green, coarse; veins green.

Commercial calue - For cut bloom poor; landscape value medium. Variety as a whole medium.

\section{MAY DAVIDSON.}

Species - P. albiflora.

Donated by Cottage Gardens Company.

Origin unknown.

Description of bloom - Type of bloom single. Form of bloom flat, two rows of guards. Color (total effect) pale lilac rose I (I78); guards clear; center a mass of yellow stamens; silver tipped bloom. One of the largest singles in existence. Fragrance pleasant XX. Blooming time mid-season. Very large size.

Description of plant-Habit of plant erect, tall, compact. Growth strong and healthy. Stem long, very strong, reddish green. Blooming habit free. Buds bornc in clusters, healthy. Foliage well furnished, dark green, medium size; veins reddish green.

Commercial ralue - For cut bloom poor; landscape value good. Variety as a whole good. 


\section{VESTA.}

Specics - P. albifiora.

Originated by Kelway.

Donalcd by Farr.

Description of bloom - Type of bloom single. Color (total effect) violet rose I (154); guards clear. Fragrance unpleasant XX. Blooming time early. Large size.

Description of plant - Habit of plant erect, medium tall, medium compact. Growth medium strong, healthy. Stem medium long, strong, red to reddish green. Blooming habit free. Buds single. Foliage medium furnished, medium green, medium size; veins reddish green.

Commercial value - For cut bloom poor; landscape value medium. Variety as a whole medium.

Remarks - Similar to "Emily," possibly not as strong grower and slightly later season.

Red

Species - P. albiflora.

\section{AUSTIN CHAMBERLAIN.}

Donated by Farr.

Description of bloom - Type of bloom single. Color (total effect) amaranth red 4 (168); collar specked light. Fragrance unpleasant XXX. Blooming time early. Large size.

Description of plant - Habit of plant erect, tall to medium, compact. Growth strong and healthy. Stem medium long, strong, reddish green. Blooming habit free. Buds borne in clusters. Foliage very well furnished, medium green, medium size; veins reddish green.

Commercial ralue-For cut bloom poor; landscape value good. Variety as a whole good.

Remarks - Similar to "The King" but better furnished, more compact grower, more petals, freer bloomer.

Species - P. albiflora.

\section{AUTUMNUS.}

Donated by Farr.

Description of bloom - Type of bloom single. Form of bloom flat. Color (total effect) amaranth red 4 (I68); guards clear. Fragrance unpleasant X. Blooming time extra early. Size medium.

Description of plant-Habit of plant erect, medium to dwarf, medium compact. Growth strong and healthy. Stem medium length, medium strength, red. Blooming habit medium. Buds of laterals developed (seldom). Foliage well furnished, medium green, medium size; veins red.

Commcrcial zalue - For cut bloom poor; landscape value medium. Variety as a whole medium to poor.

Remarks-Same color as "Austin Chamberlain" but not as free bloomer and more dwarf.

\section{FLAG OF WAR.}

Species - P. albiflora.

Originated by Kelway.

Donated by Farr.

Description of bloom - Type of $1,100 m$ single. Color (total effect) purple garnet 4 (I65); guards clear. Fragrance unpleasant XX. Blooming time early. Large size. 
Description of plant-Habit of plant erect, tall, compact. Growth strong and healthy. Stem long, strong, vivid red. Blooming habit medium. Buds single. Foliage medium furnished, dark green, medium size; veins red.

Commercial value-For cut bloom poor; landscape value good. Variety as a whole good.

Rcmarks - Similar to "Frank Bramley" but darker foliage, darker red stems, and slightly brighter bloom, not quite as large, blooms single.

\section{FRANK BRAMLEY.}

Species - P. albiflora.

Originated by Kelway.

Donated by Farr.

Descriplion of bloom - Type of hloom single. Color (total effect) rosy magenta 4 (I69); guards clear; bloom has slight silver reflex. Fragrance unpleasant XX. Blooming time early. Size very large.

Description of plant-Habit of plant erect, tall, compact. Growth strong and healthy. Stem long, strong, reddish green. Blooming habit free. Buds borne in clusters. Foliage weil furnished, dark green to medium green, medium size; veins red.

Commercial zalue - For cut bloom poor; landscape value good. Variety as a whole good.

Species - P. albifiora.

\section{JUPITER.}

Donated by Farr.

Description of bloom - Type of bloom single. Color (total effect) rosy magenta 3 (I69) ; guards clear. One of the most attractive single blooms of this color. Fragrance unpleasant XX. Blooming time early. Size medium to large.

Description of plant-Halsit of plant erect, medium tall, compact. Growth strong and healthy. Stem medium long, strong, red. Blooming habit very free. Buds borne in clusters, healthy. Foliage well furnished, light green, medium size to fine; veins reddish green.

Commerial a alue - For cut hloom ponr; landscape value extra good. Variety as a whole extra good.

Remarks - Light green foliage distinguishes it from all other red singles. One of the best. Distinct from "Jupiter" (Calot, I867).

\section{MILLAIS.}

Species - P. albiflora.

Originated by Kelway.

Donated by Farr.

-Description of bloom - Type of bloom single. Color (total effect) dark crimson 4 (I68); guards clear. Fragrance unpleasant XX. Blooming time early. Very large size.

Descriplion of plant - Ifahit of plant erect, tall, medium compact. Growth strong and healthy. Stem long, strong, red. Blooming habit free. Buds borne in clusters. Foliage medium furnished, medium green to dark green, medium size; veins reddish green.

Commcrcial zaluc-For cut bloom poor; landscape value good. Variety as a whole medium.

Remarks - Similar to "Flag of War," but not as dark stems or foliage, larger bloom. 


\section{STANLEY.}

Specics - P. albiflora.

Originated by Kelway.

Donated by Farr.

Discripion of bloom - Type of bloom single. Color (total effect) dark crimson 5 ( $16_{5}$ ) ; guards clear. Fragrance unpleasant $\mathrm{X}$. Blooming time early to midseason. Large size.

Discription of plant - Habit of plant erect, medium tall, medium compact. Growth strong and healthy. Stem medium long, strong, vivid red. Blooming habit free. Buds borne in clusters. Foliage medium furnished, dark green, medium size; veins red.

Commercial zalue - For cut bloom poor; landscape value good. Variety as a whole good.

Remarks - Not as tall a grower as "Frank Bramley," possibly a heavier bloomer. "Stanley" is the better of the two varieties.

This variety should not be confused with "Stanley" (Crousse, 1879), which is a double sort. See Bulletin 278, page 292.

\section{THE KING.}

Species - P. albiflora.

Originated by Kelway.

Donated by Farr.

Description of bloom - Type of bloom single. Color (total effect) 4-5 (I60) aniline red. Fragrance unpleasant XX. Blooming time early. Medium size. Description of plant - Habit of plant erect, medium tall, compact. Growth strong and healthy. Stem medium long to long, medium to strong, red. Blooming habit medium. Buds borne in clusters, slight blight. Foliage medium furnished, dark green to medium, medium size; veins red.

Commercial a aluc - For cut bloom poor; landscape value medium. Variety as a whole medium.

\section{JAPANESE TYPE}

\section{MODESTY.}

\section{White}

Specics - P. albiflora.

Originated by Kelway.

Donated by Hollis.

Description of bloom - Type of bloom Japanese. Form of bloom flat, loose. Not entirely transformed. Differentiated. Color (total effect) white; guards clear, milk white; center clear, cream white. Hairy, green carpels, white stigmas. Fragrance pleasant XX. Blooming time mid-season. Large size.

Description of plant - Habit of plant medium erect, medium height, medium compact. Growth medium strong, healthy. Stem medium long, strong, reddish green. Blooming habit medium. Buds borne in clusters, healthy. Foliage well furnished, dark green, fine; veins reddish green.

Commercial value - For cut bloom poor; landscape value poor. Variety as a whole poor.

Species - P. albiflora.

Originated by Kelway.

Donated by Farr.

Description of bloom - Type of bloom Japanese. Differentiated. Int entirely transformed. Color (total effect) lilac white; guards clear; center clear, amber yellow. Double row of guards. Fragrance unpleasant X. Blooming time early to mid-season. Medium size. 
Description of plant - Halit of plant erect, medium to dwarf, compact. Growth strong and healthy. Stem medium long to short, strong, green. Blooming habit free. Buds borne in clusters. Foliage well furnished, light green, medium size; veins green.

Commercial z'uluc - For cut bloom medium; landscape value extra good. Variety as a whole extra good.

Remarks - One of the most attractive Japanese blooms in the trade.

\section{Pink and White}

\section{CINDERELLA.}

Species - P. albiflora.

Originated by Hollis.

Donated by Hollis.

Description of bloom - Type of bloom Japanese. Form of bloom globular, medium compact. Differentiated. Not entirely transformed. Color (total effect) mauve and cream; guards 4 (I8I) pure mauve, streaked light; center cream white. Fragrance unpleasant X. Blooming time mid-season. Size medium.

Description of plant-Habit of plant very erect, medium to tall, compact. Growth strong and healthy. Stem long, strong, red. Blooming habit free. Lateral buds undeveloped. Foliage well furnished, dark green, medium size; veins reddish green.

Commercial value - For cut bloom poor; landscape value medium. Variety as a whole medium to good.

\section{Pink}

\section{HITY TITY.}

Species - P. albiflora.

Donated by Hollis.

Description of bloom - Type of bloom Japanese. Form of bloom globular, very loose. Differentiated. Not entirely transformed. Color (total effect) pale lilac rose 2 ( 178$)$; guards clear; center cream, clear. Green carpels, white stigmas. Fragrance unpleasant $\mathrm{X}$. Blooming time mid-season. Small size. Description of plant-Habit of plant erect, dwarf, compact. Growth medium strong, diseased. Stem short, medium strong, recldish green. Blooming habit shy. Lateral buds undeveloped, blight. Foliage well furnished, medium green, fine; veins green.

Commcrial value - For cut bloom poor; landscape value poor. Variety as a whole worthless.

Specics - P. albiflora.

\section{INNOCENCE.}

Donated by Hollis.

Description of bloon - Type of bloom Japanese. Form of bloom flat, medium compact to loose. Differentiated. Not entirely transformed. Color (total effect) I (I52) lilac rose; guards clear; center canary yellow fading to cream white. Hairy, pale, yellowish green carpels and yellow stigmas. Fragrance pleasant X. Blooming time mid-season. Medium size.

Description of plant-Habit of plant erect, tall, compact. Growth strong and healthy. Stem long, strong, green. Blooming habit free. Buds borne in clusters. Foliage well furnished, medium green, medium size; veins reddish green.

Commercial zaluc-For cut bloom poor; landscape value medium. Variety as a whole medium. 


\section{SUNBEAM.}

Species - P. albiflora.

Originated by Hollis, 1904.

Donated by Farr.

Descriplion of bloum - Type of bloom Japanese. Form of bloum that, loose. Differentiated. Not entirely transformed. Color (total effect) I (I29) pale rose pink; guards clcar; guards fade to lilac white; center canary yellow I (I7) fading to cream white. Fragrance pleasant X. Blooming time mid-season. Medium size.

Descrifion of flunt - Habit of plant crect, medium tall, compact. Growth strong and healthy. Stem medium long, strong, reddish green. Blooming habit medium. Buils borne in clusters, healthy. Foliage well furnished, medium green, medium size; veins reddish green.

Commercial value - For cut bloom poor; landscape value good. Variety as a whole medium.

\section{SUNRISE.}

Specics - P. albiflora.

Originated by Hollis, I908.

Donated by Hollis.

Description of bloom - Type of bloom Japanese. Form of bloom globular, medium compact to compact. Differentiated. Entirely transformed. Color (total effect) pale lilac rose I (I78); guards clear; center clear, canary yellow. Strong blooms produce crown of $\mathrm{I}$ or 2 petals flecked crimson. Fragrance pleasant X. Blooming time mid-season. Large size.

Description of plunt - Habit of plant medium erect to drooping, tall, medium compact. Growth strong and healthy. Stem long, strong, reddish green. Blooming habit free. Buds borne in clusters, healthy. Foliage well furnished, dark green, very coarse; veins rec.

Commercial value - For cut bloom poor; landscape value medium. Variety as a whole medium.

\section{ATTRACTION.}

\section{Red}

Specics-P. albiflora.

Originated by Hollis, 1906.

Donated by Farr.

Description of bloum - Type of bloom Japanese. Form of bloom flat, medium compact. Differentiated. Not entirely transformed. Color (total effect) tyrian rose 4 (155); guards, tyrian rose, clear; center clear. Center same color as guards, tipped with yellow, fades more quickly than guards. Fragrance pleasant $X$. Blooming time mid-season. Very large size.

Discription of plant-Habit of plant erect, medium to tall, compact. Growth strong and healthy. Stem long, strong, reddish green. Blooming habit free. Buds borne in clusters, healthy. Foliage well furnished, medium to light green, medium size; veins reddish green.

Commercial zalue - For cut bloom poor; landscape value medium. Variety as a whole medium.

Species - P. albifiora.

\section{CROWN OF THORNS.}

Donated by Hollis.

Description of bloom - Type of bloom Japanese. Form of bloom medium globular, compact. Differentiated. Not entirely transformed. Color (total effect) I (Ifog) rosy magenta; guards clear; collar same as guards; center clear. 
Smooth, green carpels, yellow stigma. Center fades much lighter than the guards. Fragrance pleasant XX. Blooming time early. Size medium to small.

Description of plant - Habit of plant erect, medium tall, compact. Growth strong, slightly diseased. Stem medium long, medium strong, reddish green. Blooming liabit medium. Buds borne in clusters. Slight blight. Foliage well furnished, medium green, fine; veins red.

Commercial vialue - For cut bloom poor; landscape value poor. Variety as a whole poor.

Species - P. albiflora.

FLASHLIGHT.

Donated by Farr.

Description of bloom - Type of bloom Japanese. Form of bloom globular, medium compact to loose. Differentiated. Not entirely transformed. Color (total effect) tyrian rose I (I55); guards have slight streak; center clear. The center is amber yellow, shading pink at base. Fragrance unpleasant $\mathrm{X}$. Blooming time early. Very large size.

Description of plant - Habit of plant erect, medium height, compact. Growth strong and healthy. Stem medium long, strong, red. Blooming habit free. Buds borne in clusters. Foliage well furnished, dark green, medium size: vcins red.

Commerciul ralu - For cut bloom poor; landscape value medium. Variety as a whole medium.

Species - P. albiflora.

Donated by Farr.

Description of bloom - Type of bloom Japanese. Form of bloom flat, medium compact to loose. Color (total effect) I (155) tyrian rose; guards clear; center goldien yellow. Bloom on strong plants, petals same color as guards will likely develop in center of bloom; silver tip. Fragrance unpleasant X. Blooming time mid-season to late. Size medium.

Description of plant-Habit of plant erect, medium tall, medium compact. Growth strong. Stem medium long, medium strong, reddish green. Blooming habit free. Buds borne in clusters, healthy. Foliage well furnished, dark green to medium, fine; veins reddish green.

Commercial zalue - For cut bloom poor; landscape value medium. Variety as a whole medium.

Species - P. albiflora.

GYPSY.

Donated by Farr.

Description of bloom - Type of bloom Japanese. Form of bloom flat, loose. Differentiated. Entirely transformed. Color (total effect) 5 (I55) tyrian rose ; guards clear; center of bloom same color as guards. Does not fade as quickly as "Attraction." Fragrance unpleasant X. Blooming time mid-season. Large size.

Descripticn of plant - Hahit of plant erect, medium tall, medium compact. Growth strong and healthy. Stem long to medium, medium strong, reddish green. Blooming habit free. Buds borne in clusters, healthy. Foliage well furnished, medium green, fine; veins green to reddish green.

Commercial vilue-For cut bloom poor; landscape value good. Variety as a whole good. 
PRINCE ALERT.

Species - P. albiflora.

Originated by Hollis, rgo4.

Donated by Hollis.

Description of bloom - Type of bloom Japanese. Form of bloom flat, medium compact. Differentiated. Not entirely transformed. Color (total effect) I ( 55 ) tyrian rose; guards clear; center clear; center pale pink with yellow remnants. Carpels pale green, pinkish white stigmas. Fragrance pleasant X. Blooming time late. Small to very small size.

Description of plant-Habit of plant erect, dwarf, compact. Growth medium strong, diseased. Stem short, strong, reddish green. Blooming habit shy. Buds borne in clusters, blight. Foliage well furnished, dark green, medium size; veins green.

Commercial valuc-For cut bloom poor; landscape value poor. Variety as a whole worthless.

Species - P. albiflora.

Originated by Hollis, 1908 .

Donated by Hollis.

Description of bloom - Type of bloom Japanese. Form of bloom globular, loose. Differentiated. Not entirely transformed. Color (total effect) I (I55) tyrian rose; guards have light streaks; center same color as guards. Hairy, green carpels, white stigmas. Fragrance pleasant $\mathrm{X}$. Blooming time midseason. Small size.

Description of plant - Iabit of plant erect, medium tall, medium compact to compact. Growth strong and healthy. Stem medium long, medium strong to weak, red. Blooming habit medium. Lateral buds undeveloped, blight. Foliage well furnished, dark green, fine; veins red.

Commercial zalue-For cut bloom poor; landscape value poor. Variety as a whole poor.

Remarks - Not an attractive bloom.

\section{White}

\section{ANEMONE TYPE}

\section{GOLDEN WEDDING.}

Spccies - P. albiflora.

Originated by Pleas.

Donated by Cottage Gardens Company.

Description of bloom - Type of bloom anemone. Form of bloom globular, loose. Differentiated. Not entirely transformed. Color (total effect) yellowish white; guards splashed with rosy white; center canary yellow, clear. Carpels green, yellow stigmas. Bloom fades to creamy white center. Fragrance pleasant X. Blooming time early. Size large.

Description of plant - Hahit of plant erect, tall, medium compact. Growth strong and healthy. Stem long, strong, reddish green. Blooming habit free. Buds borne in clusters. Foliage medium furnished, medium green, medium size; veins red.

Commercial valuc - For cut bloom poor; landscape value medium. Variety as a whole medium. 


\section{MORNING STAR.}

Species - P. albiflora.

Originated by Terry.

Donated by Farr.

Description of bloom - Type of bloom anemone. Form of bloom flat, loose.

Differentiated. Not entirely transformed. Color (total effect) milk white; guards flecked with crimson. Very strong blooms produce petals in centet with crimson flecks; $4-8$ carpels, red stigmas. Fragrance pleasant X. Blooming time mid-season. Medium to small size.

Description of plant - Habit of plant erect, medium height, compact. Growth strong and healthy. Stem medium long, strong, green. Blooming habit free. Buds singie, healthy. Foliage well furnished, light green, medium size; veins green.

Commercial ralue - For cut bloom poor; landscape value good. Variety as a whole good.

Species - P. albiflora.

\section{YOUTH.}

Donated by Hollis.

Description of bloom - Type of bloom anemone. Form of bloom flat, loose. Differentiated. Not entirely transformed. Color (total effect) milk white; guards clear; center cream white, clear. Hairy, green carpels, white stigmas; very strong blooms occasionally show crown. Fragrance pleasant X. Blooming time mid-season. Medium to large size.

Description of plant - Habit of plant meciium erect, tall, compact. Growth strong and healthy. Stem long, strong, green to reddish green. Blooming habit free. Buds borne in clusters, healthy. Foliage well furnished, dark grcen, medium size; veins reddish green.

Commercial z'alue-For cut bloom poor; landscape value poor. Variety as a whole poor.

\section{Pink and White}

AURORA.

Species - P. albiflora.

Originated by Hollis.

Donated by Hollis.

Description of bloon - Type of bloom anemone. Form of bloom globular, loose. Not differentiated. Not entirely transformed. Color (total effect) solferino red 2 ( 157$)$; guards clear; center cream to milk white, clear; secondary staminodes absent; linear petals. Strong blooms have few central petals same color as guards, flecked. Fragrance lacking. Blooming time mid-season. Size medium to large.

Description of plant - Habit of plant efect, medium to tall, very compact. Growth strong and healthy. Stem medium length, strong, reddish green. Blooming habit frec. Bucls borne in clusters, healthy. Foliage well furnished, medium green, medium size, veins green.

Commerciul r'aluc - For cut bloom poor; landscape value, medium to good. Variety as a whole medium.

Remarks - "Arcadia" cannot be distinguished except that it may be a slightly lower growing plant. This should not be confused with "Aurora" originated by Mrs. Pleas, see Bulletin 278, page 237, nor with "Aurore" (Dessert). 
Pink

Species - P. albifiora.

Donated by Pleas.

Description of bloom - 'Type of bloom anemone. Form of bloom globular, very loose. Differentiated. Not entirely transformed. Color (total effect) pale lilac rose; guards clear; collar cream white, lighter than guards; center clear; secondary staminodes absent. Green, hairy carpels, cream stigmas, crown formed by few large petals on strong blooms. Central petals $1 / 4$ inch wide. Fragrance unpleasant $\mathrm{X}$. Blooming time early to mid-season. Large size.

Description of plant - Habit of plant erect, medium tall, compact. Growth strong and healthy. Stem medium long, strong, green. Blooming habit frce. Buds borne in clusters, healthy. Foliage well furnished, dark green, fine; veins reddish green.

Commercial iulue - For cut bloom poor; landscape value medium. Variety as a whole medium to poor.

\section{AUGUSTE LEMONIER.}

\section{Red}

Spccies - P. albiflora.

Originated by Calot, 1865.

Donated by Kline.

Description of bloom - Type of bloom anemone. Form of bloom flat, medium compact. Differentiated. Not entirely transformed. Color (total effect) reddish violet; guards, 3-4 (I80), clear; center uniform color. Fragrance pleasant X. Blooming time mid-season. Medium to small in size.

Description of plant - Habit of plant erect, medium height, medium compact. Growth strong and healthy. Stem medium long, strong, reddish green. Blooming habit medium. Buds borne in clusters. Foliage well furnished, dark green, medium size; veins reddish green.

Commercial a'alue - For cut bloom medium; landscape value medium. Variety as a whole medium.

\section{CURIOSITY.}

Species - P. albiflora.

Originated by Dessert \& Mechin, I886.

Donated by Cottage Gardens Company.

Description of bioom - Type of hloom ancmone. Weak blooms are nearly single, while very strong ones may be semi-double. Form of bloom medium globular, compact. Differentiated. Not entirely transformed. Color (total effect) 4 ( ISo ) reddish violet; guards clear; collar same as guards : center clear, tipped yellow. Green carpels, pink stigmas, occasional wide petal appearing in center. Fragrance pleasant X. Blooming time mid-season. Large size.

Description of plant - Habit of plant erect, tall, medium compact. Growth strong and healthy. Stem long, strong, reddish green. Blonming habit free. Buds borne in clusters, healthy. Foliage medium furnished, medium green, fine; veins reddish green.

Commercial salue - For cut bloom medium; for landscape value medium. Variety as a whole medium.

Species - P. albiflora.

\section{EUREKA.}

Donated by Farr.

Descriplion of bloom - Type of bloom anemone. Form of bloom globular, compact. Differentiated. Not entirely transformed. Color (total effect) + (I55) 
tyrian rose; guards streaked light in center; collar same as guards; center clear. The very strong blooms have a tendency to produce low crown. Fragrance unpleasant $\mathrm{X}$. Blooming time mid-season. Small size.

Descriplion of piant - Habit of plant medium erect, medium height, medium compact. Growth strong and healthy. Stem medium long, medium strong, red. Blooming habit medium to shy. Lateral buds undeveloped, healthy. Foliage well furnished, dark green, fine; veins red.

Commercial s'aluc-For cut bloom poor; landscape value poor. Variety as a whole poor.

\section{L'AVENIR.}

Specics - P. albiflora.

Originated by Calot, 1868.

Donated by Farr.

Discription of bloom - Type of bloom anemone. Form of bloom globular, medium compact. Color (total effect) I ( 80 ) reddish violet; guards clear; center yellow and reddish violet. Fragrance pleasant X. Blooming time midseason. Medium size.

Description of plant-Habit of plant erect, tall, compact. Growth strong and healthy. Stem long, very strong, grcen. Blooming habit free. Buds borne in clusters, healthy. Foliage well furnished, dark green, medium to fine in size; veins red.

Commercial zalue - For cut bloom ponr: landscape value medium. Variety as a whole medium.

Species - P. albifiora.

\section{ROSEA MAGNA.}

Donated by Biue Hill Nursery.

Description of Uloom - Type of bloom anemone. Form of bloom globular, loose. Differentiated. Not entirely transformed. Color (total effect) I (I69) rosy magenta; guards clear; center milk white, clear. Red carpels and red stigmas. Strong blooms have center mixed with petals of the same color as guards. Usually the central petals are $1 / 4$ inch wide. Fragrance pleasant X. Blooming time mid-season. Large size.

Description of plant - Habit of plant medium erect, tall, compact. Growth strong and healthy. Stem long, strong, reddish green. Blooming habit free. Buds borne in clusters, healthy. Foliage medium furnished, medium green, coarse; veins green.

Commercial zulue - For cut bloom poor; landscape value poor. Variety as a whole poor.

\section{SEMI-DOUBLE TYPE}

\section{Pink and White}

\section{MADAME COURANT.}

Species - P. albiflora.

Donated by De Graff Brothers.

Originated by Courant, 1850.

Description of bloom - Type of bloom semi-double. Form of bloom flat, medium compact. Not differentiated. Color (total effect) pink and white; guards clear 2 (I54) violet rose; center clear, fades lilac white; secondary staminodes absent. Smooth, green carpels and cream stigmas. Fragrance unpleasant XX. Blooming time mid-season. Large size.

Description of plant-Habit of plant medium erect to drooping, tall, compact. 
Growth strong and healthy. Stem long, strong, red. Blooming habit free. Buds borne in clusters, healthy. Foliage well furnished, dark green, coarse; veins red.

Commercial a'alue-For cut bloom poor; landscape value medium. Variety as a whole medium.

Synonyms - "Phoenica Variegata," "Perfection."

\section{Pink}

Species - P. albiflora.

\section{DAYBREAK.}

Originated by Hollis, I909.

Donated by Farr and Hollis.

Description of bloom - Typc of bloom semi-double. Form of bloom flat, loose.

Not differentiated. Not entirely transformed. Color (total effect) violet rose 4 (I54); guards clear; uniform color throughout; center clear 4 (I5t). Fragrance unpleasant XX. Blooming time early. Size large.

Description of plunt - Habit of plant medium erect, medium height, medium compact. Growth strong and healthy. Stem long, strong, reddish green. Blooming habit medium. Buds borne in clusters. Foliage medium furnished, medium green, medium size; veins reddish green.

Commercial value - For cut bloom poor; landscape value good. Variety as a whole good.

Species - P. albiflora.

\section{EVENING GLOW.}

Donated by Hollis.

Description of bluom - Type of bloom semi-double. Form of bloom flat, medium compact. Not differentiated. Not entirely transformed. Color (total effect) hydrangea pink I (132) tipped with white, uniform color. Stamens are plainly visible in the center of the bloom when fully open. Imbricated bloom. Fragrance pleasant XX. Blooming time early. Size very large.

Description of plant - Habit of plant medium erect to erect, tall, compact. Growth strong and healthy. Stem long, strong, reddish green. Blooming habit free. Buds borne in clusters, healthy. Foliage well furnished, dark green, coarse: veins reddish green.

Commercial ialue - For cut bloom medium: landscape value good to extra good.

Variety as a whole good.

Remarks - The center of the bloom fades pure white.

\section{GENERAL CUSTER.}

Species $-\mathrm{P}$. albiflora.

Originated by. Terry.

Donated by Thurlow.

Description of bloom - Type of bloom semi-double. Form of bloom globular. loose. Not differentiated. Not entirely transformed. Color (total effect) light violet rose I (I54); guards streaked; center clear; uniform color throughout. Fades to white in center and tips of petals. Fragrance unpleasant XX. Blooming time mid-season. Size large.

Description of piant-Habit of plant medium erect, medium height, compact. Growth strong and healthy. Stem medium long, strong, reddish green. Blooming habit medium. Buds borne in clusters, healthy. Foliage well furnished, medium green, coarse; veins green.

Commcrial zalue-For cut bloom poor; landscape value medium. Variety as a whole medium. 


\section{HARRIET BEECHER STOWE.}

Specics - P. albiflora.

Originated by Hollis, 1907.

Donated by Hollis.

Description of bloom - Type of bloom semi-double. Form of bloom flat, loose. Not differentiated. Not entirely transformed. Color (total effect) hydrangea pink; fades to milk white in center; guards flecked and streaked crimson; center clear, lighter; secondary staminodes absent. Fragrance unpleasant XXX. Blooming time mid-season to early. Large size.

Description of plant - Habit of plant erect, medium tall to tall, compact. Growth strong and healthy. Stem long, strong, red. Blooming habit free. Buds borne in clusters, healthy. Foliage medium furnished, dark green, coarse; veins red.

Commercial salue - For cut bloom poor; landscape value medium to poor. Variety as a whole medium to poor.

\section{MADAME CARPENTIER.}

Species - P. albiflora.

Originated by Delache, 1850.

Donated by Dessert.

Description of bloom - Type of bloom semi-double. Form of bloom flat, loose. Not differentiated. Not entirely transformed. Color (total effect) violet rose 3 (I54); guards flecked; collar lighter than guards; center flecked with crimson; secondary staminodes absent. The center of bloom fades to lilac white. Fragrance pleasant X. Blooming time mid-season. Large size.

Descriftion of plant - Habit of plant medium erect, medium height, medium compact. Growth medium strong, healthy. Stem medium long, strong, red. Blooming habit free. Buds borne in clusters, healthy. Foliage well furnished, dark green, fine; veins red.

Commercial value - For cut bloom medium; landscape value good. Variety as a whole medium to good.

\section{MADAME JOANNA SALLIER.}

Specics - P. albiflora.

Donated by Shaylor and McKissock.

Originated by Paillet.

Description of bloom - Type of bloom semi-double. Form of bloom globular, medium compact. Not differentiated. Not entirely transformed. Color (total effect) 4 (I54) violet rose; guards flecked with crimson, splashed with crimson; collar same color as guards; center prominently flecked with crimson. Fragrance unpleasant X. Blooming time early to mid-season. Large size.

Description of plant - Hahit of plant crect, tall, medium compact. Growth strong and healthy. Stem long, strong, reddish green. Blooming habit free. Buds borne in clusters, healthy. Foliage medium furnished, medium to dark green, medium size; veins red.

Commerciul ialuc - For cut bloom medium: landscape value medium. Variety as a whole medium.

\section{NE PLUS ULTRA.}

Species - P. albiflora.

Originated by Miellez, 1856 .

Donated by Farr.

Description of bloom - Type of bloom semi-double. Form of bloom flat, loose. 
Not differentiated. Not entirely transformed. Color (total effect) pure mauve; uniform color throughout I (ISI); bloom silver tipped, slight splash. Fragrance pleasant X. Blooming time early to mid-season. Medium size. Description of plent - Habit of plant medium erect, medium tall, medium compact to open. Growth strong. Stem medium long, medium strong, red. Blooming hahit free. Ibuds single, healthy. Inoliage medium furnisherl, light green, medium size; veins reddish green.

Commercial calue - For cut bloom poor; landscape value medium. Variety as a whole medium.

\section{SOUTH WEYMOUTH.}

Species - P. albiflora.

Originated by Hollis. Donated by Hollis.

Description of bloom - Type of bloom semi-double. Form of bloom flat, loose. Not differentiated. Not entircly transformed. Color (total effect) violet rose 3 (154); guards prominently splashed; collar same color as guards; center fades to lilac white, clear. Fragrance pleasant $X$. Blooming time early to mid-season, medium size.

Description of plunt - Fiabit of plant erect, medium tall, medium compact. Growth medium strong, healthy. Stem medium long, medium strong, vivid red. Blooming hahit medium. Buds borne in clusters, healthy. Foliage medium furnished, dark green, medium size; veins red.

Commercial value - For cut bloom poor; landscape value poor. Variety as a whole poor to worthless.

\section{THEODORE ROOSEVELT.}

Species - P. albiflora.

Originated by Pleas.

Donated by Wild.

Description of bloom - Type of bloom semi-double. Form of bloom flat, loose. Not differentiated. Not entirely transformed. Color (total effect) pale lilac rose I ( 178$)$; guards splashed; collar same as guards; center slightly flecked crimson; secondary staminodes absent. Color is splashed on similarly to "Asa Gray." Fragrance umpleasant X. Blooming time early to mid-season. Large size.

Description of plant - Habit of plant drooping, medium tall, medium compact. Growth strong and healthy. Stem long, strong, red. Blooming habit free. Buds borne in clusters, healthy. Foliage well furnished, dark green, coarse; veins reddish green.

Commercial value - For cut bloom poor; landscape value poor. Variety as a whole poor.

Remarks - "Delachei" has been confused with and sold under the above name.

Species - P. albiflora.

\section{WELCOME GUEST.}

Donated by Farr.

Description of bloom - Type of bloom semi-double. Form of bloom loose. Not differentiated. Not entirely transformed. Color (total effect) bright rose I ( 128 ) ; guards clear; collar same color as guards; center clear. Bloom fades in sun. Fragrance pleasant XX. Mid-season. Large size. 
Description of plant - Habit of plant erect, tall, medium compact. Growth strong and healthy. Stem long, strong, red. Blooming habit free. Buds borne in clusters. Foliage medium furnished, medium green, coarse to medium in size; veins red.

Commcrcial z'ulue - For cut bloom medium: landscape value medium. Variety as a whole medium.

\section{ADOLPHE ROUSSEAU.}

\section{Red}

Species - P. albiflora.

Originated by Dessert and Mechin, 1890.

Donated by Farr.

Descriptiun of bluom - Type of bloom semi-double. Form of bloom flat, loose. Not differentiated. Not entirely transformed. Color (total effect) purple garnet 5 (165), guards streaked light, collar same as guards, center clear; secondary staminodes absent. Cream white carpels, pink stigma, stamens visible in center of bloom. Fragrance unpleasant X. Blooming time early. Size very large.

Description of plant - Habit of plant erect, tall, medium compact. Growth strong, healthy. Stem long, strong, red. Blooming habit free. Buds borne in clusters. Foliage medium furnished, dark green, medium fine; veins red.

Commercial value - Fior cut bhom poor: landscape value extra good. Variety as a whole good.

Remarks - One of the best early reds for landscape.

Specics - P. albiflora.

ANTIETAM.

Donated by Hollis.

Description of bloom - Type of bloom semi-double. Form of bloom very flat, medium compact. Not differentiated. Not entirely transformed. Color (total effect), guards dark crimson + ( 168$)$; guards streaked with white; collar same color as guards; center same as guards, clear; secondary staminodes absent. Fragrance unpleasant X. Blooming time mid-season. Small size.

Description of plmt - Habit of plant medium erect, medium to dwarf in height, compact. Growth medium strong, diseased. Stem medium to short in length, medium strong, red. Blooming habit shy. Buds have laterals undeveloped, blight. Foliage well furnished, dark green, fine; veins red.

Commercial value - For cut bloom poor; landscape value poor. Variety as a whole worthless.

\section{CHARLES DE BELLEYME.}

Spccics - P. albiflora.

Originated by Verdier, IS60.

Donated by Farr.

Description of bloom - Type of bloom semi-double. Form of bloom globular, loose. Not differentiated. Not entirely transformed. Color (total effect) dark crimson 4 (I68); collar same as guards; center clear. Some guard petals streaked lighter on lower side. Fragrance unpleasant X. Blooming time mid-season. Size medium.

Description of plant - ITalit of plant erect, medium tall, compact. Growth strong and healthy. Stem medium long, strong, red. Blooming habit free. Buds borne in clusters, healthy. Foliage well furnished, medium green, medium size; veins red. 
Commercial zulue - For cut bloom poor; landscape value good. Variety as a whole medium.

Remarks - There may be a slight doubt as to the identity of this variety.

\section{CONTINENTAL.}

Species-P. albiflora.

Originated by Hollis, 1905 .

Donated by Hollis.

Description of blenm - Type of bloom semi-double. Form of blenm flat, loose. Not differentiated. Not entirely transformed. Color (total effect) magenta 4 (182); guards flecked scarlet; uniform color, clear. Fades silver tipped, broad petals, imbricated bloom, yellow stamens visible at center. Fragrance unpleasant X. Blooming time mid-season. Size large.

Description of finnt - Halit of plant erect, medium tall, very compact. Growth strong and healthy. Stem long, strong, red. Blooming habit free. Buds borne in clusters, healthy. Foliage well furnished, light green, coarse; veins red.

Commercial ruluc - For cut bloom poor; landscape value good. Tariety as a whole medium.

\section{DESCARTES.}

Spccies - P. albiflora.

Originated by Dessert \& Mechin, I885.

Donated by Shaylor.

Description of bloom - Type of bloom semi-double. Form of bloom flat, loose. Not differentiated. Not entirely transformed. Color (total effect) aniline red 4 ( 160$)$; guards clear; collar same as guards; center streaked light. Fragrance pleasant X. Blooming time mid-season. Size large.

Description of plant-Habit of plant erect, tall, compact. Growth strong and healthy. Stem long, strong, reddish green. Blooming habit free. Buds borne in clusters, healthy. Foliage well furnished, dark green, medium size; veins reddish green.

Commorcial z'alue - For cut hloum poor: landscape value very good. Variety as a whole medium to good.

\section{EUGENE REIGNOUX.}

Specics - P. albiflora.

Originated by Dessert.

Donated by Farr.

Description of bloom - Type of bloom semi-double. Form of bloom globular, loose. Not differentiated. Not entirely transformed. Color (total effect) magenta 4 (I82); guards have occasional light streak; collar same as guards; center clear. Fragrance unpleasant X. Blooming time early to mid-season. Size large.

Description of fiant- Hahit of plant erect, medium height, medium compact. Growth strong. Stem medium long, strong, reddish green. Blooming habit free. Buds borne in clusters, healthy. Foliage well furnished, medium to dark green, medium size; veins red.

Conmercial zalue - For cut bloom medium; landscape value medium. Variety as a whole medium. 


\section{JOHN HANCOCK.}

Species - P. albiflora

Originated by Hollis, 1907.

Donated by Hollis.

Description of bloom - Type of bloom semi-double. Form of bloum globular, loose. Not differentiated. Not entirely transformed. Color (total effect) 4 (I69) rosy magenta; guards streaked light; center clear; secondary staminodes absent. Lloom is very noticeably silver tipped. Fragrance unpleasant XX. Blooming time mid-season. Medium size.

Description of flant - Habit of plant erect, medium height, compact. Growth strong and healthy. Stem long, medium strong to strong, red. Blooming habit free. Buds borne in clusters, healthy. Foliage well furnished, medium green, medium size; veins reddish green.

Commercial value - For cut bloom medium; landscape value medium. Variety as a whole medium.

\section{LA SUBLIME.}

Species - P. albiflora.

Originated by Parmentier, 1850.

Donatcd by Perennial Gardens.

Description of bloom - Type of bloom semi-double. Form of bloom flat, loose. Not differentiated. Not entirely transformed. Color (total effect) 5 (I68) dark crimson; guards streaked light; collar same color as guards; center clear. Carpels pale yellow, pink stigmas, smooth. Fragrance unpleasant XX. Blooming time mid-season. Large size.

Description of plant - Habit of plant erect, tall, medium compact. Growth strong and healthy. Stem long, strong, reddish green. Blooming habit free. Buds borne in clusters, healthy. Foliage medium furnished, dark green, fine; veins green.

Commercial value - For cut hloom poor; landscape value medium. Variety as a whole medium.

Species - P. albiflora.

Originated by Hollis.

Donated by Hollis.

Description of bloom - Type of bloom semi-double. Form of bloom globular, loose. Not differentiated. Not entirely transformed. Color (total effect) dark crimson 5 (I68); guards streaked light; center same as guards, clear. Green carpels, smooth, pink stigmas. Fragrance unpleasant X. Blooming time mid-season. Medium to small size.

Description of plant-Habit of plant erect, medium height, compact. Growth strong and healthy. Stem medium long, medium strong, reddish green. Blooming habit medium to free. Lateral buds undeveloped, healthy. Foliage medium furnished, dark green, medium to fine in size; veins red.

Commercial value - For cut bloom poor; landscape value poor. Variety as a whole worthless.

Remarks - Very unattractive, loose bloom.

NICO.

Species - P. albifiora.

Originated by Kelway.

Donated by Farr.

Description of bloom - Type of bloom semi-double. Form of bloom globular, loose. Not differentiated. Not entirely transformed. Color (total effect) 
4 (155) tyrian rose; guards clear; collar same as guards; center clear; bloom silver tipped. Fragrance unpleasant X. Blooming time mid-season. Very large size.

Description of pl:mint-Habit of plant medium erect, tall, open. Growth strong and healthy. Stem long, medium strong, reddish grcen. Blouming habit free. Buds borne in clusters, healthy. Foliage well furnished, light green, medium size; veins reddish green.

Commercial salue - For cut bloom poor; landscape value medium. Variety as a whole medium.

Rcinur's - This varicty was originally catalogued by Kelway as a single varicty, but seems to be gradually doubling under cultivation.

\section{RUBRA TRIUMPHANS.}

Species-P. albiflora.

Originated by Delache, 1854 .

Donated by Farr.

Discriftion of bloom-Type of bloom semi-double. Form of bloom globular, loose. Not differentiated. Not entirely transformed. Color (total effect) 5 (168) dark crimson; guards clear; collar same as guards; center clear. Fragrance unpleasant XX. Blooming time early. Large size.

Description of plant - Habit of plant medium erect, medium tall to tall, medium compact. Growth strong and healthy. Stem long, medium strong, red. Blooming habit free. Buds borne in clusters, healthy. Foliage medium furnished, dark green, medium size; veins vivid red.

Comnercial z'iluc-For cut bloom poor; landscape value medium. Variety as a whole medium.

\section{SOUVENIR DU DOCTEUR BRETONNEAU.}

Species - P. albifiora.

Originated by Dessert, 1896.

Donated by Shaylor.

Description of bloom - Type of bloom semi-double. Form of bloom flat, loose. Not differentiated. Not entirely transformed. Color (total effect) 5 (I55) tyrian rose; guards clear; collar same as guards; center clear. Fragrance unpleasant XX. Blooming time mid-season. Medium size.

Description of plant - Habit of plant erect, medium tall, compact. Growth strong and healthy. Stem medium long, strong, reddish green. Blooming habit free. Buds horne in clusters, healthy. Foliage well furnished, medium green, medium size; veins reddish green.

Commercial valuc - For cut bloom poor; landscape value medium. Variety as a whole medium.

CROWN TYPE

\section{White}

ADELAIDE E. HOLLIS.

Species - P. albiflora.

Originated by Hollis, 190\%.

Donated by Farr and Hollis.

Descriplion of bloom.- Type of bloom crown. Form of bloom globular, medium compäct. Differentiated. Entirely transformed. Color (total effect) rose white I (8), guards clear, collar same as guards, center clear. Very clear eren pleasant color, fades to pure white. Fragrance pleasant XX. Blooming time mid-season. Size large. 
Description of plant-Habit of plant ercet, medium tall, compact. Growth strong, healthy. Stem medium long to medium strong, green. Blooming habit free. Buds borne in clusters, healthy. Foliage well furnished, light green, medium fine; veins green.

Commercial value - For cut bloom extra good; landscape value good. Value of variety as a whole extra good.

\section{ANTOINE POITEAU.}

Species - P. albiflora.

Qriginated by Guerin, $\mathbf{1} 845$.

Donated by Charlton.

Discription of bloom - Type of bloom crown. Form of bloom globular, medium compact. Differentiated. Entirely transformed. Color (total effect) lilac white; guards clear; collar milk white, lighter than guards; center flecked with crimson, same color as guards; secondary staminodes present. Opens like bomb but develops to low crown. Fragrance pleasant X. Blooming time mid-season. Medium size.

Description of plunt - Habit of plant medium to drooping, tall, medium compact. Growth strong, healthy. Stem long, strong, green. Blooming habit free. Buds undeveloped, healthy. Foliage medium furnished, medium green, fine; veins green.

Commerciul iulue - For cut bloom good; landscape value medium. Variety as a whole medium to good.

Species - P. albiflora.

\section{BLANCHE CIRE.}

Donated by Cottage Gardens Company.

Description of bloom - Type of bloom crown. Form of bloom medium compact.

Differentiated. Entirely transformed. Color (total effect) cream white; guards clear; collar same as guards; center clear; secondary staminodes present. Fragrance pleasant X. Blooming time early. Medium size.

Description of plant-Habit of plant erect, medium tall, medium compact. Growth medium, healthy. Stem medium long, medium strength, reddish green. Llooming habit medium. Buds borne in clusters, slight blight. Foliage medium furnished, medium green, medium size; veins green.

Commercial ialue - For cut bloom good; landscape value medium. Variety as a whole good.

Species - P. albiflora.

Donaicd by Shaylor from Dessert.

Origin unknown

Description of bloom - Type of bloom crown. Form of bloom medium globular, loose. Differentiated. Not entirely transformed. Color (total effect) I (7) lilac white; guards clear; collar canary yellow when bloom first opens; center clear. Red stigma, smooth, green carpels. Fragrance unpleasant XX. Blooming time mid-season. Size medium to large.

Descriftion of plint - Hahit of plant medium erect, medium tall, medium compact. Growth strong and healthy. Stem medium long, strong, reddish green. Blooming habit medium. Buds borne in clusters, healthy. Foliage well furnished, dark green, medium size; veins reddish green.

Commerciul inluc - For cut blonm good; landscape value good. Variety as a whole good. 


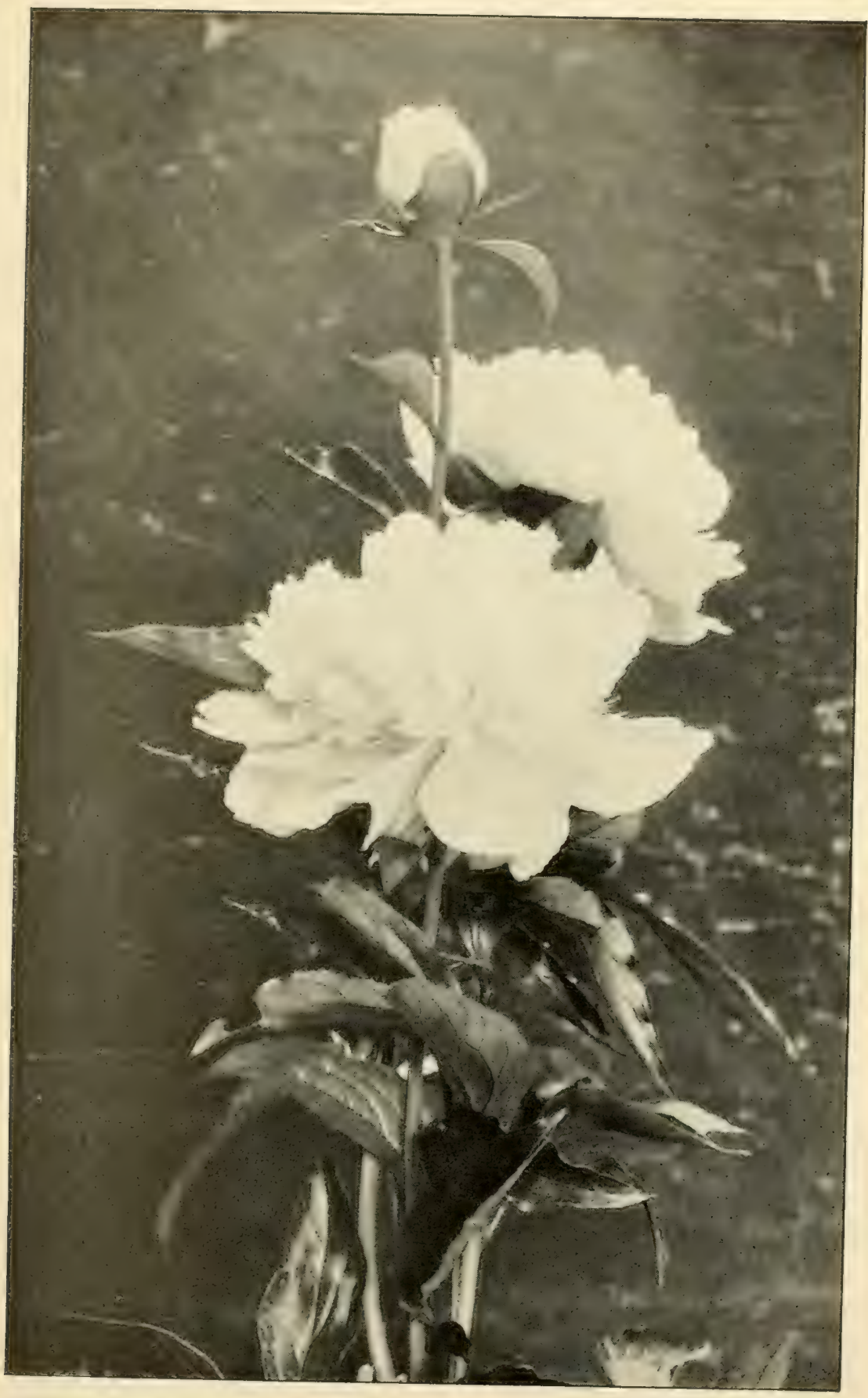

Octave Demay (crown type) 



\section{LA VESTALE.}

Species - P. albiflora.

Originated by Calot, 1870.

Donated by Cottage Gardens Company.

Discription of bloom - Type of blesm crown. Form of bloom tall, mediun compact, Differentiated. Entirely transformed. Color (total effect) lilac white; guards slightly splashed; collar cream white; center lilac white flecked with crimson. Fragrance unpleasant X. Blooming time mid-season. Medium size.

Description of plant-Habit of plant erect, tall, compact. Growth strong and heaithy. Stem long, strong, reddish green. Blooming habit free. Buds borne in clusters, healthy. Foliage well furnished, medium green, medium size to coarse; veins green.

Commercial value - For cut bloom good; landscape value good. Variety as a whole good.

\section{MADAME GUYOT.}

Species- P. albiflora.

Originated by Paillet.

Donated by McKissock.

Description of bloom - Type of bloom crown. Form of bloom globular, compact. Differentiated. Not entirely transformed. Color (total effect) I (I5) greenish white; guards clear, slightly tinted with light pink; collar darker than guards, 2 (I8) sulphur yellow; center flecked with crimson. Fragrance pleasant XX. Blooming time mid-season. Medium to large size.

Description of plant-Habit of plant medium erect, tall, medium compact. Growth strong and healthy. Stem medium long, medium strong to strong, reddish green. Blooming habit free. Buds single, laterals undeveloped, healthy. Foliage medium furnished, medium green, coarse; veins reddish green.

Commercial value - For cut bloom good; landscape value good. Variety as a whole good.

Species - P. albiflora.

Originated by Paillet.

Donated by McKissock

Description of bloom - Type of bloom crown. Form of bloom globular, compact. Differentiated. Not entirely transformed. Color (total effect) lilac white; guards clear; collar cream yellow I (30); center flecked with scarlet. Fragrance unpleasant $\mathrm{X}$. Blooming time mid-season to early. Large size.

Description of plunt - Habit of plant erect, tall, medium compact. Growth strong and healthy. Stem long, medium strong, green. Blooming habit free. Buds borne in clusters, healthy. Foliage well furnished, medium green, medium size; veins green.

Comncriul iduc - For cut bloom extra good; landscape value good. V'ariety as a whole extra good.

\section{MARCELLE DESSERT.}

Species - P. albiflora.

Originated by Dessert, I899.

Donated by Farr.

Description of bloom - Type of hloom crown. Form of bloom tall, medium compact. Differentiated. Entirely transformed. Color (total effect) milk white; guards slightly flecked with scarlet, splashed with lilac: center slinhtly flacked with crimson. Bloom very highly built. Fragrance pleasant XXX. Blooming time mid-season. Large size. 
Description of plant - Habit of phnt medium erect, medium height, medium compact. Growth strong, healthy. Stem medium long, medium strong, red. ỉlooming habit medium. Buds single. Foliage well furnished, dark green, medium; veins reddish green.

Commercial zaluc - For cut bloom good: landscape value medium. Variety as a whole good.

Srecies - P. albiflora.

MISS SALWAY.

Originated by' Kelway.

Donated by Farr.

Description of bloom - Type of bloom crown. Form of bloom globular, compact. Differentiated. Entirely transformed. Color (total effect) lilac white 2 (7); guards clear; collar lighter than guards; center clear. Fragrance pleasant $\mathrm{X}$. Blooming time mid-season. Very large size.

Dcscription of plant-Habit of plant crect, tall, compact. Growth strong and healthy. Stem long, strong, red. Blooming habit free. Buds borne in clusters, healthy. Foliage well furnished, medium green, medium size; veins reddish green.

Commercial zaluc-For cut bloom extra good; landscape value extra good. Variety as a whole extra good.

Remarks - Very similar to "Madame Lemoine"; taller crown, however, and not as compact.

Species - P. albiflora. NEPTUNE. Originated by Dessert. Donated by Farr.

Description of bloom - Type of bloom crown. Form of bloom medium compact. Differentiated. Not entirely transformed. Color (total effect) lilac white; guards clear; collar lighter than guards, milk white; center clear. Cream white stigmas. Fragrance pleasant X. Blooming time mid-season. Size large.

Description of plant - Habit of plant erect, tall, compact. Growth strong and healthy. Stem long, strong, reddish green. Blooming habit free. Buds borne in clusters, healthy. Foliage medium furnished, medium to dark green, coarse; veins reddish green.

Commercial value - For cut bloom good; landscape value good. Variety as a whole good.

\section{PRESIDENT WILDER.}

Species - P. albiflora.

Originated by Ellwanger \& Barry.

Donated by Ellwanger \& Barry.

Description of bloom - Type of bloom crown. Form of bloom globular, compact. Differentiated. Not entirely transformed. Color (total effect) lilac white 2 (7); guards clear; collar milk white, lighter than guards; center same color as guards, occasionally slightly flecked with crimson; secondary staminodes present. Very compact crown, narrow collar. Fragrance pleasant XX. Blooming time mid-șeason. Medium size.

Description of plant - Habit of plant erect, medium tall, medium compact. Growth medium strong, healthy. Stem medium iong, strong, green. Blooming habit free. Buds borne in clusters, healthy. Foliage well furnished, medium green, medium size; veins green.

Commercial z'aluc-For cut bloom good; landscape value good. Variety as a whole good. 


\section{QUEEN VICTORIA (Kelway).}

Species - P. albiflora.

Originated by Kelway.

Donated by Farr.

Description of bloom-Type of bloom crown. Form of bloom medium globular, medium compact to loose. Differentiated. Entirely transformed. Color (total effect) white; guards milk white, slightly flecked with crimson, slightly splashed crimson; collar cream white; center prominently flecked with crimson; secondary staminodes present on some blooms. Strong biooms have a low crown; weak blooms more of a loose bomb. Fragrance pleasant X. Blooming time mid-season. Large to medium size.

Description of plant - Hallit of plant erect, medium tall, compact. Growth strong and healthy. Stem medium long, strong, redlish green. Blooming habit free. Buds borne in clusters, healthy. Foliage well furnished, dark green, medium size; veins green.

Commercial s'aluc-For cut bloom medium; landscape value medium. Variety as a whole medium.

Remarks-Should not be confused with the "Queen Victoria Whitleyi" group. This variety is prominently flecked. For a description of "Whitleyi" see page ro6.

\section{SEA FOAM.}

Species - P. albiflora.

Originated by Peterson.

Donated by Cottage Gardens Company.

Description of bloom-Type of bloom crown. Form of bloom globular, medium compact. Differentiated. Entirely transformed. Color (total effect) lilac white I (7), fades to nearly pure white; guards clear; collar cream white; center clear, same color as collar. Fragrance pleasant XX. Blooming time mid-season. Large size.

Description of plant - Habit of plant erect, tall, medium compact. Growth strong and healthy. Stem long, strong, reddish green. Blooming habit free. Buds borne in clusters, healthy. Foliage well furnished, medium green, medium size; veins reddish green.

Commercial zaluc - For cut bloom good; landscape value good. Variety as a whole good.

Spccics - P. albiflora.

Originated by Lemon,. 1830.

Donated by Andorra Nurseries.

Description of bloom-Type of bloom crown. Form of bloom globular. Differentiated. Not entirely transformed. Color (total effect) milk white, slight yellowish green tint; guards clear; center clear, slight yellowish green tint at base of petals. Has a distinct cup shape when bloom first opens. Carpels hairy, cream white with white stigmas. Fragrance pleasant X. Mid-season. Large size.

Description of plant-Habit of plant medium erect to drooping, medium tall, medium compact. Growth medium strong. Stem medium long, medium strong, green. Blooming habit shy. Buds blighted. Foliage well furnished, medium green, fine in size; veins green.

Commercial valuc - For cut bloom good; landscape value medium. Variety as a whole medium to good.

Remarks - This is entirely distinct from "Alba Sulfuren." See page 102. Should not be confused with "Solfatare," see page 250, Bulletin 278. 
Species - P. albiflora.

\section{TRIUMPHATA.}

Donated by Goos and Koenemann.

Origin unknown.

Description of blocm - Type of bloom crown. Form of bloom globular, medium compact. Differentiated. Entirely transformed. Color (total effect) milk white; guards slightly streaked with crimson; collar same color as guards; center flecked with crimson; secondary staminodes present. Fragrance pleasant X. Blooming time mid-season. Medium to large size.

Description of plant--Habit of plant medium erect, tall, compact. Growth strong and healthy. Stem long, strong, reddish green. Blooming habit free. Buds borne in clusters, healthy. Foliage well furnished, dark green, medium size; veins green.

Commercial value - For cut bloom medium; variety as a whole medium.

\section{Pink and White}

Specues - P. albiflora.

Donated by Hollis.

Description of bloom - Type of bloon crown. Form of bloom tall, medium compact. Color (total effect) pink and white; guards 4 (I54) violet rose, clear; collar lighter than guards, cream white with remnants of anthers; center flecked with crimson, same color as guards; secondary staminodes present. Color fades rapidly in sunliglnt. Fragrance pleasant XX. Blooming time nidseason to late. Size large.

Description of plant-Habit of plant medium erect, medium tall, compact. Growth strong and healthy. Stem medium to long, strong, reddish green. Blooming habit free. Buds borne in clusters, healthy. Foliage medium furnished, light green, coarse; veins reddish green.

Commerial ialuc-Description of bloom poor: landscape value poor. Varicty as a whole poor.

Species - P. albiflora.

Donated by Dessert.

\section{LUTETIANA.}

Originated by Guerin, 1840.

Description of bloom - Type of bloom crown. Form of blonm globular, medium compact. Differentiated. Not entirely transformed. Color (total effect) pink and white; guards 2 (I52) lilac rose; collar lighter than guards; center clear. The weak blooms are more bomb type with clear white center. Hairy, pale carpels and pink stigmas. Fragrance pleasant XX. Blooming time midseason to late. Size medium to large.

Description of plant-Habit of plant medium erect to drooping, medium height, medium compact. Growth strong and healthy. Stem medium long, medium strong, green. Blooming habit medium. Buds. borne in clusters, healthy. Foliage medium furnished, medium green, fine; veins green.

Commercial valuc - For cut bloom medium; landscape value medium to pcor. Variety as a whole medium.

\section{MADAME LEMOINE.}

Species - P. albiflora.

Originated by Calot, 1864 .

Donated by Farr.

Description of bloom - Type of bloom crown. Form of bloom globular, very compact. Differentiated. Entirely transformed. Color (total effect) violet 
rose and milk white; guards i ( 5.5$)$, collar lighter than guaris, milk white; center crown lilac whitc; secondary staminodes prescnt. liragrance plcasant XXX. Blooming time mid-season. Large size.

Descriplion of plant-Habit of plant erect, tall, compact. Growth strong and healthy. Stem long, strong, red. Blooming habit free. Buds borne in clusters, healthy. Foliage well furnished, medium green, medium to coarse in size; veins green.

Commercial value - For cut bloom extra good; landscape value extra good. Variety as a whole extra good.

\section{MADEMOISELLE ROSE RENDATLER.}

Species-P. albiflora.

Originatcd by Calot, 1867 .

Donaled by Jackson and Perkins.

Description of bloom - Type of bloom crown. Form of bloom tall, loose. Differentiated. Not entirely transformed. Color (total effect) hydrangea pink and cream; guards hydrangea pink 4 (7); guards very clear; collar cream, lighter than guards; center flecked; secondary staminodes present. Fragrance pleasant XX. Blooming time mid-season. Large size.

Descriplion of plant-Habit of plant medium erect, medium height, medium compact. Growth strong and healthy. Stem medium long, strong, reddish green. Blooming habit medium. Buds borne in clusters, healthy. Fuliage well furnished, dark green, fine; veins reddish green.

Commercial zalue - For cut bloom medium; landscape value medium. Variety as a whole medium.

\section{MRS. JOHN SMYTHE FOGG.}

Species - P. albiflora.

Originated by Hollis, 1907.

Donaled by Hollis.

Description of bloom - Type of bloom crown. Form of bloom tall, medium compact to compact. Differentiated. Not entirely transformed. Color (total effect) pink and white; guards pale lilac fading to hydrangea pink, streaked light; collar lighter than guards, milk white; center clear, same color as guards; secondary staminodes absent. Weak blooms are more of a loose, bomb type. Fragrance pleasant X. Blooming time mid-season. Large size. Description of plant-Habit of plant erect, tall, compact. Growth strong and healthy. Stem long, strong, red. Blooming habit free. Buds borne in clusters, healthy. Foliage well furnished, medium green, coarse; veins reddish green.

Commercial a'alue - For cut bloom medium; landscape value good. Variety as a whole good.

\section{PRINCESSE NICOLAS BIBESCO.}

Species - P. albiflora.

Originated by Guerin, 1863 .

Donated by Dessert.

Description of bloom - Type of bloom low crown. Form of bloom globular compact. Differentiated. Entirely transformed. Color (total effect) hydrangea pink and cream; guards hydrangea pink I (I32), clear; collar cream white, lighter than guards, center crown same as guards, clear; secondary staminodes present. Fragrance pleasant X. Blooming time mid-season. Medium size. 
Description of plant-Habit of plant medium erect, tall, medium compact. Growth strong and healthy. Stem long, strong, reddish green. Blooming habit medium. Buds borne in clusters, healthy. Foliage well furnished, medium green, medium size; veins reddish green.

Commercial zalue - For cut bloom good; landscape value good. Variety as is whole good.

\section{Pink}

\section{BEAUTY'S MASK.}

Species - P. albiflora.

Originated by Hollis, I904.

Donated by Farr.

Discription of bloom-Type of bloom crown. Form of bloom compact. Color (total effect) violet-rose 4 ( 154 ) ; guards clear; collar lighter than guards, mixed with cream ycllow; secondary staminodes present. Fragrance pleasant $\mathrm{X}$. Blooming time late. Very large size.

Description of plant - Medium erect habit, tall, open. Growth strong and healthy. Stem long, medium strength, reddish green. Blooming habit free. Buds borne in clusters, healthy: Tioliage medium furnished, medium green, medium size, veins green.

Commercial s'alue - For cut bloom medium; landscape value good. Variety as a whole medium to good.

Species - P. albiflora.

\section{CHRISTOPHER ARCHARD.}

Dunated by Rosenfield

Origin unknown.

Dcscription of bloom-Type of bloom crown. Form of bloom globular, medium compact. Differentiated. Nearly transformed. Color (total effect) mauve rose I (I53); guards clear; collar milk white, lighter than guards; center same color as guards, flccked with crimson. Some weak blooms are typical bomb. Fragrance pleasant XX. Blooming time mid-season. Size medium to large.

Description of plant-Habit of plant medium erect, tall, medium compact. Growth strong and healthy. Stem long, strong, green. Blooming habit free. Buds borne in clusters, healthy. Foliage medium furnished, light green, fine; veins green.

Commercial vaine - For cut bloom good: landscape value good. Variety as a whole good.

\section{COMTE DE JUSSIEU.}

Specics - P. albiflora.

Originated by' Guerin, 1850.

Donated by Jackson and Perkins.

Description of blocm - Type of bloom crown. Form of bloom globular, loose. Differentiated. Entirely transformed. Color (total effect) hydrangea pink; guards streaked light; collar lighter than guards, milk white; center flecked with crimson and green; secondary staminodes present. Fragrance unpleasant X. Blooming time early. Size medium to large.

Description of plant-Habit of plant erect, medium tall, medium compact. Stem medium long, strong, reddish green. Blooming habit free. Buds borne in clusters, healthy. Foliage medium furnished, medium green, medium size; veins reddish green.

Commercial value-For cut bloom medium; landscape value medium. Variety as a whole medium.

Remarks - Identity not fully established. 


\section{COUPE D'HEBE.}

Spccies - P. albiflora.

Originated by Kelway.

Donated by Minot.

Description of bloom-Type of bloom crown. Form of bloom globular, medium compact. Color (total effect) i ( 178$)$ pale lilac rose; guards clear; collar milk white, very much lighter than guards, center same as guards, flecked crimson; secondary staminodes absent. Fragrance pleasant XX. Blooming time mid-season. Size large.

Description of plant - Habit of plant medium to erect, very tall, medium compaci, Growth strong and healthy. Stem long, very strong, green. Blooming habit free. Buds borne in clusters, healthy. Foliage medium furnished, light green, coarse; green veins.

Commercial zialuc-For cut bloom medium; landscape value medium. Variety as a whole medium.

\section{CYTHÉRÉE.}

Species - P. albiflora.

Originated by Calot, 1856 .

Donated by Shaylor.

Description of bloom - Type of bloom crown. Form of bloom globular, compact. Differentiated. Entirely transformed. Color (total effect) I (153) mauve rose; guards clear; collar lighter than guards, cream white; center prominently flecked with crimson; secondary staminodes present. Blooming time mid-season. Size medium to large.

Description of plant-Hahit of plant erect, medium to tall, compact. Growth strong and healthy. Stem long and strong. Blooming habit free. Buds borne in clusters, healthy. Foliage well furnished, nedium to light green, medium size; veins green.

Commercial z'ulue-For cut bloom good; landscape value extra good. Variety as a whole good.

Remarks-Under the above name, a white peony has often been sold by European dealers. This should not be confused with Cyntherii, see Bulletin 278, page 247 .

\section{GERMAINE BIGOT.}

Species - P. albiflora.

Originated by Dessert, 1902.

Donated by Farr.

Description of bloom - Type of bloom crown, partly concealed stamens. Form of bloom flat, medium compact. Not differentiated. Not entirely transformed. Color (total effect) pale lilac rose 2 (I30); guards splashed with crimson; collar same as guards; center prominently flecked with crimson. Fragrance unpleasant X. Blooming time mid-season. Very large size.

Descripion of plant-Habit of plant erect, medium height, medium compact. Growth strong and healthy. Stem medium long, strong, reddish green. Blooning habit free. Buds borne in clusters, healthy. Foliage well furnished, medium green, medium size; veins reddish green.

Commercial z'alue-For cut bloom good; landscape value extra good. Variety as a whole good. 
Species - P. albitiora.

\section{LA FÉE.}

Donatcd by McKissock.

Originated by Lemoine.

Description of bloom - Type of bloom crown. Form of bloom globular, compact. Differentiated. Not entirely transformed; color (total effect) mauve rose 2 (I53); guards clear; collar lighter than guards, creamy white; center clear. Fragrance pleasant XXX. Blooming time early. Large size.

Description of plunt - Habit of plant medium erect, tall, medium compact. Growth strong and healthy. Stem long, medium strong, green. Blooming habit free. Buds borne in clusters, healthy. Foliage medium furnished, very dark green, coarse; veins reddish green.

Commercial value - For cut bloom good; landscape value good. Variety as a whole good.

Rcmarks - Foliage is very distinct. Leaflets are curled uip.

\section{MADAME JULES ELIE.}

Species-P. albiflora.

Originated by Calot, 1873.

Donated by Cottage Gardens Company.

Discription of bloom - Type of bhom crown. Form of bloom globular, medium compact to loose. Differentiated. Not entirely transformed. Color (total effect) violet rose 2 (I54); guards clear; collar lighter than guards, cream white; center flecked with crimson. Fragrance pleasant XX. Blooming time mid-season. Medium size.

Description of plant - Habit of plant medium erect, medium height, compact. Growth strong and healthy. Stem medium long, strong, reddish green. ' Blooming habit medium to free. Buds borne in clusters, blight. Foliage well furnished, medium green, medium to fine in size; veins reddish green.

Commerial ciduc-For cut bloom mediun; landscape value medium. Variety as a whole medium.

Remarks - Some doubt as to the identity of this one.

\section{MYRTLE.}

Species - P. albiflora.

Originated by Terry.

Donated by Wild.

Discriftion of blonm - Type of bloom crown. Form of bloom globular, medium compact. Differentiated. Not entirely transformed. Color (total effect) hydrangea pink, fades to lilac white; guards clear; collar lighter than guards; center clear. Light green carpels, pink stigmas. When bloom first opens it is bomb; later develops low, compact crown. Fragrance pleasant XXX. Blooming time mid-scason. Size medium to small.

Description of plant-Habit of plant erect, medium height, compact. Growth strong and healthy. Stem medium long, strong, reddish green. Blooming habit free. Buds single, healthy. Foliage well furnished, medium to light green, medium size; veins green to reddish green.

Commercial value - For cut bloom medium; landscape value medium. Variety as a whole medium to good.

Remarks - Bloom is too small to make a valuable varicty. 


\section{PRINCESS OF WALES.}

Species - P. albiflora.

Originated by Kelway.

Donated by Cottage Gardens Company.

Descripion of bloom - Type oi hloom crown. liorm of bloom flat, compact. Not differentiated. Entirely transformed. Color (total effect) mauve rose I (I53) ; guards flecked with crimson; collar lighter than guards; center clear. Fragrance pleasant XX. Blooming time late. Large size.

Descriplion of plant - Habit oi plant medium erect, medium tall, medium compact. Growth strong and healthy. Stem medium long, strong, red. Blooming habit free. Buds borne in clusters. Foliage medium furnished, light green, medium to fine in size; veins reddish green.

Commercial zaluc-For cut bloom medium; landscape value medium. Variety as a whole medium.

\section{SIMONNE CHEVALIER.}

Species - P. albiflora.

Originated by Dessert, 1902.

Donated by Farr.

Descrificin of bloom-Type of bloom crown. Form of bloom medium compact to loose. Differentiated. Entirely transformed. Color (total effect) pale lilac rose I (I78); guards clear; collar cream white, lighter than guards; center same color as guards; flecked with crimson; secondary staminodes absent. Not a typical crown; collar not prominent. Fragrance pleasant XX. Blooming time early. Large size.

Description of plant-Hahit of plant medium to drooping, medium tall, medium compact. Growth medium strong. Stem medium long, medium strong, reddish green. Blooming habit medium. Buds borne in clusters. Foliage well furnished, medium green, medium size; veins reddish green.

Commerial z'alue - For cut bloom medium to poor; landscape value good. Variety as a whole medium to good.

Species - P. albiflora.

\section{TAGLIONI.}

Donated by Shaylor.

Descriptiun of bloon-Type of bloom crown. Form of bloom medium tall, medium compact. Differentiated. Entirely transformed. Color (total effect) I (I54) violet rose; guards clear; collar cream white, lighter than guards; center very prominently flecked with crimson; secondary staminodes present, cream white. Fragrance unpleasant X. Blooming time early. Medium size.

Description of plant - Habit of plant medium erect, tall, medium compact. Growth strong and healthy. Stem long, strong, green. Blooming habit free. Buds borne in clusters. Foliage medium furnished, light green, medium size; veins green to reddish green.

Commercial zalue - For cut bloom medium; landscape value medium. Variety as a whole medium.

Species - P. albiflora.

\section{VAN DYCK.}

Donated by Blue Hill Nursery.

Originated by Crousse; 1879.

Description of bloom-Type of hloom crown. Form of hloom globular, medium compact to loose. Differentiated. Not entirely transformed. Color (total eflect) mauve rose 2 ( 153 ); guards pure mauve; collar cream white, lighter 
than guards; center same color as guards, clear. Pink carpeis and pink stigmas. Fragrance pleasant XX. Blooming time mid-season. Large size.

Description of plant-Habit of plant erect, medium tall, compact. Growth strong and healthy. Stem medium long, strong, green. Blooming habit free. Buds borne in clusters. Foliage well furnished, medium green, fine; veins green.

Commircial zaluc-For cut bloom medium; landscape value medium to good. Variety as a whole medium.

Species-P. albiflora.

\section{VENUS.}

Donated by Farr.

Discription of vloon-Type of bloom crown. Form of bloom tall, medium compact. Differentiated. Color (total effect) hydrangea pink I (I32); guards clear; collar lighter than guards; center clear. Fragrance pleasant XX. Blooming time mid-season. Large to very large in size.

Description of plant-Habit of plant medium erect, very tall, medium compact. Growth strong and healthy. Stcm long, medium strong, green. Blooming habit free. Buds borne in clusters. Foliage medium furnished, medium green, medium size; veins green.

Commercial valuc-For cut bloom extra good; landscape value good. Variety as a whole extra good.

Synonyms - "Pear1," "Princess May," "Marie Stuart." (Mr. Farr thinks the Cornell "Marie Stuart" is incorrect.)

\section{VICOMTESSE DE BELLEVAL.}

Species - P. albiflora.

Donated by Ellwanger \& Barry.

Originated by Guerin, 1852.

Description of bloom - Type of bloom crown. Form of bloom flat, loose. Not differentiated. Entirely transformed. Color (totaĺ effect) hydrangea pink I (132) ; guards clear; collar cream white, lighter than guards; center same color as guards faded; secondary staminodes present, cream white. Fragrance pleasant X. Blooming time early. Medium size.

Description of plant-Habit of plant medium erect, medium tall, compact. Growth strong. Cornell specimens diseased. Stem medium long, medium strong, reddish green. Blooming habit medium. Buds horne in clisters, slightly blighted. Foliage well furnished, medium green, fine; veins reddish green. Commercial z'alue - For cut bloom medium; landscape value medium. Variety as a whole medium.

Red

\section{CLEMENTINE GILLOT.}

Species-P. albiflora.

Donated by Farr and Goos and Koenemann.

Originated by Crousse, 1885 .

Description of bloom-Type of hloom crown. Form of bloom tall, medium compact. Differentiated. Not entirely transformed. Color (total effect) I (I55) tyrian rose; guards clear; collar same as guards; center clear. Bloom fades violet rose in the sun. Fragrance lacking. Blooming time late. Large size. 
Description of plant - Habit of plant crect, tall, compact. Growth strong and healthy. Stem long, strong, green. Blooming habit medium. Lateral buds undeveloped. Foliage well furnished, medium green, coarse; veins green.

cimnicrcial z'alue - For cut bloom good; landscape value good. Variety as a whole good.

\section{ELIE CHEVALIER.}

Species-P. albiflora.

Originated by Dessert, 1908.

Donated by Farr.

Description of bloom - Type of bloom crown to bomb. Form of bloom globular, medium compact. Not differentiated. Entirely transformed. Color (total effect) 2-3 (I55) tyrian rose; guards splashed with green; collar same as guards; center flecked scarlet; uniform color throughout. Fragrance pleasant X. Blooming time mid-season. Size large.

Description of plant - Halsit of plant drooping, tall. Growth medium to open. Stem long, medium strong, red. Blooming habit free. Buds single. Foliage medium furnished, medium green, medium to fine size; veins reddish green.

Commerial a alui-For cut bloom good; landscape value medium. Variety as a whole good.

Species - P. albiflora.

Originated by Hollis, 1909.

Donated by Hollis.

Description of bloom - Type of bloom crown. Form of bloom globular, compact. Differentiated. Entirely transformed. Color (total effect) tyrian rose I (I55); guards clear; collar same as guards; center clear; uniform color throughout; secondary staminodes present. Fragrance pleasant X. Blooming time very late. Medium to small size.

Description of plant - Habit of plant erect, tall, medium compact. Growth medium strong, healthy. Stem long, medium strong, reddish green. Blooming habit medium. Lateral buds undeveloped. Foliage medium to poorly furnished, dark green, fine; veins green.

Commercial i'aluc-For cut bloom poor; landscape value medium. Variety as a whole medium to poor.

\section{MADAME BIGOT.}

Species - P. albiflora.

Originated by Dessert, 1893

Donated by Cottage Gardens Company.

Description of bloom - Type of hloom crown. Form of bloom globular, compact. Differentiated. Entirely transformed. Color (total effect) I (I55) tyrian rose; guards clear; collar lighter than guards, slight silver tip; center clear; sccondary staminodes present. Fragrance unpleasant X. Blooming time mid-season. Large size.

Description of plant-Habit of plant medium erect, medium height, compact. Growth medium strong, healthy. Stem medium long, strong, reddish green. Blooming labit medium. Buds borne in clusters, tend to blight. Foliage well furnished, medium green, medium size; veins reddish green.

Commercial i'alus-For cut hloom medium; landscape value medium. Variety as a whole medium. 


\section{PURPUREA SUPERBA.}

Specics-P. albiflora.

Originated by Delache, 1855 .

Donated by Ellwanger \& Barry.

Descriphon of bloom - Type of bloom crown. Form of bloom globular, compact. Differentiated. Color (total effect) \& (169) rose magenta; guards streaked white; center clear; uniform color throughout. Light green carpels, pink stigma. Fragrance unpleasant $\mathrm{X}$. Blooming time mid-scason. Large size.

Descriplion of plant - Habit of plant erect, very tall, medium compact. Growth strong and healthy. Stem very long, strong, reddish green. Blooming habit free. Buds borne in clusters. Foliage medium furnished, medium green, medium size; veins green.

Commercial valuc-For cut bloom medium; landscape value good. Variety as a whole good.

\section{BOMB TYPE}

\section{ALBA SULFUREA.}

Species - P. albifiora.

Originated by Calot, 1860 .

Donated by Cottage Gardens Company.

Description of bloom - Type of bloom bomb. Form of bloom globular, compact.

Differentiated. Not entirely transformed. Color (total effect) cream white, guards clear, collar same as guards, center very slightly flecked. stigmas red but fully concealed, very close examination showing a very minute fleck. Fragrance pleasant $\mathrm{X}$. Blooming time mid-season. Size very large to large. Description of plant-Habit of plant medium erect, tall, medium compact. Growth strong, healthy. Stem long, strong, green. Blooming habit free. Buds borne in clusters, healthy. Foliage well furnished, medium green, medium fine; veins green.

Commercial zalue-For cut bloom extra good; landscape value good. Variety as a whole good.

Remarks - Distinct and superior to "Sulfurea," also more compact. "Sulfurea" has cream white stigmas, while stigmas of "Alba Sulfurea" are red.

\section{ALBERT CROUSSE.}

Species - P. albiflora.

Originated by Crousse, 1893

Donated by Cottage Gardens Company.

Description of bloon - Type of bloom bomb. Form of bloom flat, compact. Not differentiated. Entirely transformed. Color (total effect) rose white 3 (8), guards clear, collar same as guards, center flecked slightly crimson. Fragrance pleasant. Blooming time late. Very large size.

Description of plant - Hahit of plant erect, tall, medium compact. Growth strong, healthy. Stem long, strong, reddish green. Blooming habit frec. Buds borne in clusters, healthy. Foliage medium furnished, medium green, medium fine; veins green.

Commercial adulue - For cut bloom extra good: landscape value good. Variety as a whole good. 


\section{ALICE DE JULVÉCOURT.}

Species - P. albiflora.

Originated by Pele, 1857.

Donatcd by Cottage Gardens Company and Andorra Nurseries.

Description of bloom-Type of bloom bomb. Bloom is rather variable, as a crown type fower often appears. Form of bloom globular, compact. Differentiated. Entirely transformed. Color (total effect) lilac white, clear, collar cream, lighter than guards, center lilac white, prominently flecked with crimson; secondary staminodies present. Fragrance pleasant $\mathrm{X}$. Blooming time midseason. Medium size.

Description of piant-Habit of plant erect, medium tall, very compact. Growth strong, healthy. Stem medium long, strong, green. Blooming habit free. Buds borne in clusters, healthy. Ioliage well furnished, dark green, medium size; veins green.

Commercial zalue - For cut bloom good; landscape value good. Variety as a whole good.

Synonyms - "Triumphans Gandavensis."

\section{CANARIENSIS.}

Siecies-P. albiflora.

Oriain unknown.

Donated by Storrs and Harrison.

Description of bloom-Type of bloom bomb. Form of bloom globular, compact. Differentiated. Not entirely transformed. Color (total effect) cream white; guards clear, milk white; center cream white with few flecks of crimson. Most of average blooms are not flecked. Fragrance pleasant $\mathrm{X}$. Blooming time mid-season. Medium size.

Description of plant - Habit of plant medium erect, tall, medium compact. Growth strong and healthy. Stem long, strong, green. Blooming habit medium. Buds horne in clusters, healthy. Foliage medium furnished, medium green, medium size; veins green.

Commercial value - For cut bloom good; landscape value good. Varicty as a whole good.

Remarks - Very similar to "Duc de Vellington"; however, the latter variety never has any crimson flecks. This variety is distinct from "Canari," see Bulletin $2,-8$, page 23I.

\section{DELECOURT VERHILLE.}

Spccies - P. albiflora.

Originated by Delecourt Verhille, I86o.

Donated by Cottage Gardens Company.

Description of bloom-Type of bloom bomb. Form of hloom globular, medium compact. Differentiated. Not entirely transformed. Color (total effect) lilac white; center milk white, flecked with crimson. Carpels red, pink stigmas. Fragrance unpleasant X. Blooming time mid-season., Large size.

Description of plant-Habit of plant erect, medium height, compact. Growth strong and healthy. Stem medium long, strong, reddish green. Blooming habit free Buds borne in clusters, healthy. Foliage well furnished, dark green, medium size; veins reddish green.

Commcrial value-For cut bloom good; landscape value good. Variety as a whole good. 


\section{EDULIS ALBA.}

Species-P. albiflora.

Origin unknown, 1835 .

Donated by Cottage Gardens Company.

Description of bloom - Type of bloom bomb. Form of bloom tall, loose, slight crown. Differentiated. Entirely transformed. Color (total effect) lilac white; guards clear; center cream white, fades to milk white, flecked with crimson. Some blooms have low crown, same color as guards. Fragrance pleasant XX. Blooming time very early. Size medium to large.

Description of plant-Habit of plant drooping, medium tall, medium compact. Growth strong and healthy. Stem long, medium strong, reddish green. Blooming habit free. Buds borne in clusters, healthy. Foliage well furnished, dark green, coarse; veins reddish green.

Commercial value - For cut bloom good; landscape value medium. Variety as a whole medium to good.

\section{ELEGANS SUPERBISSIMA.}

Species - P. albiflora.

Originated by Buyck, 1842.

Donated by Shaylor.

Description of bloom - Type of bloom bomb. Form of bloom medium globular, medium compact. Color (total effect) lilac white I (7); center cream white, clear. Yellow carpels with green stigmas. Fragrance pleasant XXX. Blooming time mid-season. Medium size.

Description of plant - Habit of plant erect, tall, compact. Growth strong and healthy. Stem long, strong, green. Blooming habit free. Buds borne in clusters, healthy. Foliage well furnished, medium green, coarse; veins green.

Commercial value - For cut bloom good; landscape value good. Variety as a whole good.

\section{GRIZZEL MUIR.}

Species - P. albiflora.

Originated by Kelway.

Donated by Cottage Gardens.

Description of bluom - Type of bloom bomb. Form of bloom globular, compact. Not differentiated. Entirely transformed. Color (total effect) creamy white; guards clear; collar same as guards; center clear. Fragrance unpleasant X. Blooming time late. Large size.

Description of plant - Habit of plant erect, tall, medium compact. Growth strong and healthy. Stem long, medium strong, green. Blooming habit free. Buds borne in clusters, tend to blight. Foliage medium furnished, medium green, medium size; veins green.

Commercial value - For cut bloom good; landscape value good. Variety as a whole good.

\section{MADEMOISELLE VAILLANT.}

Species - P. albiflora.

Origin unknown.

Donated by Farr.

Description of bloom - Type of bloom bomb. Form of bloom globular, loose. Not differentiated. Not entirely transformed. Color (total effect) milk white; guards clear; center cream white; secondary staminodes absent. Smonth, pale green carpel, pink stigmas. Fragrance pleasant XX. Blooming time early. Size large to very large. 
Description of plant - Description of plant erect, medium tall to tall, compact. Growth strong and healthy. Stem long, very strong, redelish green. Blooming habit free. Buds borne in clusters, healthy. lioliage well furnished, medium green, medium to fine in size; veins green.

Commercial zalue - For cut bloom good; landscape value good. Varicty as a whole geod.

\section{NIVEA PLENISSIMA.}

Species-P. albitlora.

Originated by Makoy, 1840

Donated by Farr.

Description of bloom-Type of bloom bomb. Form of bloom globular, medium compact. Differentiated. Not entirely transformed. Color (total effect) milk white; guards slightly splashed crimson; center clear; secondary staminodes absent. Carpels red, short hairs, might transform to flecked petals on old plants. Fragrance pleasant X. Blooming time early. Large size.

Descriplion of plant-Habit of plant erect, dwarf, compact. Growth strong. Stem short, strong, dark red. Blooming habit free. Buds borne in clusters, healthy. Foliage well furnished, dark green, medium size; veins red.

Commercial value - For cut bloom good; landscape value extra good. Variety as a whole good to extra good.

Remarks-Dark red stems and white bloom are distinguishing characters of variety.

Correction to Bulletin 259. The above is a much better description of this variety

\section{RARE BROCADE.}

Species-P. albiflora.

Originated in Japan.

Donated by Rosenfield.

Description of bloom - Type of bloom bomb. Form of bloom flat, loose. Differentiated. Not entirely transformed. Color (total effect) pure white; guards occasionally flecked with crimson: center cream white, clear; secondary staminodes absent. Green, smooth carpels, pink stigmas; some blooms have tendency toward crown type. Fragrance pleasant X. Blooming time midseason. Size medium.

Description of plant - Habit of plant medium erect, medium tall, medium compact. Growth strong and healthy. Stem medium long, medium strong, green. Blooming habit free. Buds borne in clusters, healthy. Foliage well furnished, light green, medium size; veins green.

Commercial valuc-For cut bloom medium; landscape value medium. Variety as a whole medium.

\section{REINE VICTORIA.}

Species - P. albiflora.

Originated by Guerin, 1845 .

Donated by Cottage Gardens Company and Blue Hill Nursery.

Description of bloom - Type of bloom bomb. Form of bloom globular, medium compact. Differentiated. Entirely transformed. Color (total effect) lilac white and cream. Guards clear, lilac white; center cream white fading to milk white, flecked with crimson. Bases of central petals have cream tints, tips fading milk white. Tips of central petals have pinkish tint. Fragrance nearly lacking. Blooming time mid-season. Medium size. 
Description of plant-Habit of plant medium erect, medium tall, medium compact. Growth strong and healthy. Stem medium long, medium strong, green. Blooming habit medium to free. Buds borne in clusters, healthy. Foliage well furnished, dark green, medium size to fine; veins reddish green.

Commercial value - For cut bloom medium; landscape value medium. Variety as a whole medium.

Remarks-This variety should not be confused with "Whitleyi," "Queen Victoria" group, see below, or "Queen Victoria" (Kelway), see page 93.

\section{SABINA.}

Species-P. albiflora.

Origin unknown.

Donaled by Goos and Koenemann.

Description of bloom - Type of bloom bomb. Form of bloom globular, loose. Differentiated. Not entirely transformed. Color (total effect) milk white; guards clear; collar same as guards; center same, clear. Red, hairy carpels, pink stigmas. Fragrance pleasant XX. Blooming time mid-season. Medium size.

Description of plant-Habit of plant erect, tall, compact. Growth strong and healthy. Stem long, strong, green. Blooming habit free. Buds borne in clusters, healthy. Foliage well furnished, light green, coarse; veins green.

Commercial value - For cut bloom medium; landscape value medium. Variety as a whole medium.

\section{WHITLEYI.}

Species - P. albiflora.

Donated by Andorra Nursery and John Charlton.

Originated by Whitley, 1808 .

Description of bloom - Type of bloom bomb. Form of bloom globular, loose.

Differentiated. Not entirely transformed. Color (total effect) milk white; guards slightly flecked with crimson; collar same color as guards; center clear. Hairy carpels, pink stigmas; bloom opens up exposing carpels with age. Fragrance pleasant $\mathrm{X}$. Blooming time mid-season. Medium size.

Description of plant - Habit of plant medium erect, medium tall, medium compact. Growth strong and healthy. Stem medium long, strong, green. Blooming habit free. Buds horne in clusters, healthy. Foliage well furnished, dark green, fine in size; veins green.

Commercial value - For cut bloom medium; landscape value medium to poor. Variety as a whole medium.

Synonyms_-"Quecn Victoria," "Papilionacea," "Snow White," "Rosa Barry," "Stewart's America."

\section{Pink and White}

Species - P, albiflora.

Originated by Guerin, 1840.

Donated by Dessert.

Description of bloom - Type of bloom bomb. Form of bloom flat, loose. Differentiated. Not entirely transformed. Color (total effect) pink and white; guards I (I52) lilac rose, clear; center milk white, clear. Carpels greenish red, smooth; pink stigmas. Strong blooms, show center flecked with crimson. Fragrance pleasant X. Blooming time mid-season. Medium size.

Dcscription of plant - Habit of plant erect, medium height, compact. Growth strong and healthy. Stem medium length, strong, reddish green. Blooming habit medium. Buds borne in clusters, healthy. Foliage well furnished, medium green, medium size; veins green. 
Commercial a'ulue - For cut bloom ponr; landscape value medium. Variety as a whole medium.

Remarks - "Dr. Bretonneau" (Verdier) has been sold for the above varicty, but there should be no confusion.

\section{Pink}

\section{ADMIRAL DEEWEY.}

Specics-P. albiflora.

Originated by Hollis, 1903 .

Donaied by Hollis.

Description of bloom - Type bomb. Form of bloom, globular compact. Differentiated. Entirely transformed. Color (total effect) solferino red (I57-2), clear; guards solferino red (I57-2), clear; center same as guards; fades silver tipped, linear petals concealed throughout bloom. Fragrance pleasant $\mathrm{X}$. Blooming time mid-season. Size medium.

Description of plant-Habit erect, medium to tall, compact. Growth strong, healthy. Stem medium long, strong, green. Blooming habit free. Buds borne in clusters, healthy. Foliage medium furnished, medium green, coarse; veins reddish green.

Commercial zulue-For cut blooms poor; landscape value medium. Variety as a whole poor.

Remarks-There are many better varieties of this type.

\section{CERES.}

Species - P. albiflora.

Originated by Verdier, I860.

Donated by Cottage Gardens Company.

Description of bloom-Type of bloom bomb. Form of bloom medium globular, loose. Differentiated. Not entirely transformed. Color (total effect) pale lilac rose I ( $I 78)$; center very minutely flecked with scarlet. Red stigmas. Fragrance pleasant $\mathrm{X}$. Blooming time very early. Large size.

Description of plant-Habit of plant medium erect, tall, medium compact. Growth strong and healthy. Stem long, strong, reddish green. Blooming habit free. Buds borne in clusters, healthy. Foliage well furnished, dark green, medium to coarse; veins red.

Commercial salue - For cut bloom medium: landscape value good. Variety as a whole good.

\section{COMTE DE NANTEUIL.}

Species - P. albiflora.

Originated by Calot, 1858 .

Donated by Farr.

Description of blnom - Type of bloom bomb. Form of bloom globular, medium to loose. Differentiated. Not entirely transformed. Color (total effect) violet rose 2 (154); guards clear; collar lighter than guards; center clear, salmon pink. Occasional wide petal in center same as guard. Fragrance pleasant XXX. Blooming time mid-season. Large size.

Descrintion of plant-Habit of plant erect, tall, medium compact. Growth strong. healthy. Stem long, strong, green. Blooming habit free. Buds borne in clusters, healthy. Foliage medium furnished, light green, fine; veins green.

Commerial zaluc-For cut bloom medium; landscape value medium. Variety as a whole medium. 


\section{DEPARTING SUN.}

Species-P. albiflora.

Donated by Rosenfield.

Description of bloom - Type of bloom bomb. Form of bloom flat, loose. Differentiated. Not entirely transformed. Color (total effect) pale lilac rose I (I78) ; guards splashed; collar same as guards; center same as guards, flecked with crimson. Smooth, greenish carpels, pink stigmas, color laid on in splashes; loose, unattractive bloom. Fragrance unpleasant XXX. Blooming time mid-season. Size medium.

Description of plant-Habit of plant erect, medium height, compact. Growth strong and healthy. Stem medium long, strong, green. Blooming habit free. Buds borne in clusters, healthy. Foliage well furnished, medium green, medium size; veins green.

Commercial value - For cut bloom poor; landscape value poor. Variety as a whole poor.

Species - P. albifiora.

FAVORITE.

Originated by Terry.

Donutcd by Farr.

Description of bloom - Type of bloom bomb. Form of bloom globular, loose.

Not clearly differentiated. Not entirely transformed. Color (total effect) I

(154) violet rose; guards clear; collar same as guards; center clear; uniform color. Greenish red carpels, pink stigmas. Bloom silver tipped. Fragrance pleasant X. Blooming time mid-season to late. Medium size.

Description of plunt - Habit of plant medium erect to drooping, medium height, medium compact to open. Growth strong and healthy. Stem medium long to long, strong, green. Blooming habit free. Buds borne in clusters, healthy. Foliage medium furnished, light green, coarse; veins green.

Commercial value - For cut bloom poor; landscape value poor. Variety as a whole poor.

\section{GENERAL BEDEAU.}

Species - P. albiflora.

Originated by Calot, 1860.

Donated by Farr.

Description of bloom - Type of bloom bomb. Form of bloom globular, medium compact. Color (total effect) 3 ( I57) solferino red; guards clear; collar same as guards; center clear. Fragrance pleasant XXX. Blooming time mid-season. Size medium.

Description of plant-Habit of plant erect, medium height, compact. Growth strong. Stem medium long, strong, green. Blooming habit free. Buds borne in clusters, healthy. Foliage well furnished, light green, medium size; veins green.

Commercial z'aluc-For cut bloom medium; landscape value good. Variety as a whole medium.

\section{GLORY OF SOMERSET.}

Species - P. albiflora.

Originated by Kelway.

Donated by Cottage Gardens Company.

Description of bloom-Type of bloom bonb, informal. Form of bloom fat, loose. Color (total effect) 3 (I54) violet rose; guards clear; collar cream white, lighter than guards; center clear cream white and mixed with petals same 
color as guards. Carpels green with red stigmas. Fragrance pleasant XX. Blooming time mid-season. Large size.

Description of plant-Habit of plant erect, medium height, compact. Growth strong and healthy. Stem medium long, strong, green. Blooming habit free. Buds borne in clusters, healthy. Foliage well furnished, medium to dark green, medium size; veins green.

Commercial ialue - Ior cut blowm medium; landscape value good. Variety as a whole good.

Species - P. albitlora.

Origin unknown.

Donated by Goos and Koenemann.

Description of bloom-Type of bloom bomb. Form of bloom globular, loose.

Differentiated. Not entirely transformed. Color (total effect) pale lilac rose: guards clear; center clear, fades milk white. Greenish red carpels, pink stigmas. Strong blooms have few wide petals same color as guards in center of bloom. Fragrance pleasant XX. Blooming time mid-season to late. Meditm size.

Description of plant - Habit of plant erect, tall, compact. Growth strong and healthy. Stem long, strong, green. Blooming habit free. Buds borne in clusters, healthy. Foliage well furnished, medium green, medium size; veins green.

Lommercial z'aluc-For cut bloom poor; landscape value medium. Variety as a whole medium.

\section{I,A FONTAINE.}

Specics - P. albiflora.

Donated by Farr.

Description of bloom-Type of bloom bomb. Form of bloom globular, compact.

Differentiated. Entirely transformed. Color (total effect) violet rose 2 (I54); guards clear; collar lighter than guards; center flecked with crimson. Guard petals very wide; lighter, narrow petals intermixed around the collar; center petals same color as guards. Fragrance pleasant $\mathrm{X}$. Blooming time mid-season to late. Large size.

Description of plant - Habit of plant medium erect, tall, compact. Growth strong. Stem medium long to long, strong, reddish green. Blooming habit medium. Lateral buds occasionally undeveloped. Foliage well furnished, medium green, coarse; veins red.

Commercial salue-For cut bloom good; landscape value extra good. Variety as a whole extra good.

Rcmarks - A very delicately colored variety, uniform shade, distinct from "La Fontaine" (Dessert, I893) catalogued by Dessert, which is a crimson variety.

Specics - P. albiflora.

\section{MADAME COSTÉ.}

Donated by Cottage Gardens Company.

Description of bloom - Type of bloom crown to bomb. Form of hloom globular, medium compact. Differentiated. Entirely transformed. Color (total effect) I (I,32) hydrangea pink; guards clear; collar cream white, lighter than guards; center flecked with crimson. Some blooms are bomb, while others have low crown. Fragrance pleasant XX. Blooming time early. Medium size. 
Description of plant - Habit of plant medium erect, medium height, medium compact. Growth strong and healthy. Stem medium long, medium strong, reddish green. Blooming habit free. Buds borne in clusters, healthy. Foliage medium furnished, light green, fine; veins green.

Commercial value - For cut bloom good; landscape value good. Variety as a whole good.

Synonym - "Queen Esther."

\section{MARIE CROUSSE.}

Species - P. albiflora.

Originated by Crousse, 1892.

Donated by Farr.

Description of bloom - Type of bloom bomb. Form of bloom globular, medium to loose. Differentiated. Not entirely transformed. Color (total effect) I (I30) pale lilac rose; guards clear; collar same as guards; center clear. Fragrance unpleasant XX. Blooming time mid-season. Large to medium size. Description of plant - Habit of plant erect, tall, compact. Growth strong and healthy. Stem long, medium strong, green. Blooming habit free. Buds borne in clusters, healthy. Foliage medium furnished, medium green, medium to fine in size; veins green.

Commercial zalue - For cut bloom extra good; landscape value good. Variety as a whole good to extra good.

\section{MEADOWVALE.}

Species - P. albifiora.

Originated by Hollis, 1903.

Donated by Hollis.

Description of bloom-Type of bloom bomb. Form of bloom globular, compact.

Differentiated. Not entirely transformed. Color (total effect) 4 (I57) solferino red; guards clear; center occasionally flecked, same as guards. Hairy, yellow carpels, pink stigmas. Strong blooms showing tendency toward crowns.

Fragrance pleasant XX. Blooming time mid-season. Medium size.

Description of plant-Habit of plant medium erect, medium height, compact.

Growth strong and healthy. Stem medium long, strong, reddish green.

Blooming habit free. Buds borne in clusters, healthy. Foliage well furnished, light green, coarse; veins green.

Commercial value - For cut bloom medium; landscape value medium to good.

Variety as a whole medium to good.

Remarks - This variety is no real advance over many others of this color.

\section{MONSIEUR JULES ELIE.}

Species-P. albiflora.

Originated by Crousse, 1888.

Donated by Farr.

Description of bloom - Type of bloom bomb. Form of bloom medium compact. Differentiated. Entirely transformed. Color (total effect) pale lilac rose; guards clear; center clear 2 ( $I 78)$; secondary staminodes present; collar tinted lighter than guards. Very attractive pink, base of collar petals amber yellow. Fragrance pleasant XX. Blooming time early. Large size.

Description of plant - Habit of plant medium erect, medium height, medium compact. Growth medium strong. Stem medium long, green. Blooming habit free. Foliage medium furnished, medium green, medium size; veins green. Commercial zaluc - For cut bloom very good; landscape value very good. Variety as a whole very good. 


\section{POMPON CHAMOIS.}

Species-P. albiflora.

Originated by Verdier, 1860.

Donated by Shaylor.

Description of bloom - Type of bloom bomb. Form of bloom shohular, compact.

Differentiated. Not entirely transformed. Color (total effect) 2 (154) violet rose; guards clear; collar canary yellow, lighter than guards; strong blooms have center same color as guards, streaked yellow; weak blooms have whole center yellow. Green carpels, pink stigmas. Fragrance unpleasant X. Biooming time mid-season. Small size.

Description of plant-Habit of plant drooping, medium tall, medium compact. Growth strong and healthy. Stem medium long, medium strong, reddish green. Blooming habit medium. Buds borne in clusters, healthy. Foliage medium furnished, dark green, fine; veins red.

Commercial value - For cut bloom poor; landscape value poor. Variety as a whole poor.

\section{ROSEA ELEGANS.}

Species-P. albiflora.

Originated by Guerin, 1858 .

Donated by Charlton.

Description of bloom - Type of bloom bomb. Form of bioom globular, compact.

Differentiated. Not entirely transformed. Color (total effect) pale lilac rose; guards clear; collar cream white, fading to milk white; center clear; secondary staminodes absent. Occasionally central petals appear same color as guards, flecked with crimson. Fragrance pleasant X. Blooming time early. Medium size.

Description of plant- Habit of plant medimm erect to drooping, tall, open. Growth strong and healthy. Stem long, strong, reddish green. Blooming habit free. Buds borne in clusters, healthy. Foliage medium furnished, medium green, fine; veins green.

Commercial value - For cut bloom medium; landscape value medium. Variety as a whole medium.

\section{ROSILITA.}

Species-P. albiflora.

Originated by Hollis, 1977 .

Donated by Hollis.

Description of bloom - Type of bloom bomb. Form of bloom globular, loose. Differentiated. Not entirely transformed. Color (total effect) 2 (I5ł) violet rose; guards clear; center clear, milk white; secondary staminodes present. Hairy, green carpels, white stigmas. Fragrance pleasant X. Blooming time mid-season. Medium size.

Description of plant - Habit of plant medium erect, medium tall, compact. Growth strong and healthy. Stem medium length, strong, reddish green. Blooming habit free. Buds borne in clusters, healthy. Foliage well furnished, dark green, fine; veins reddish green.

Commercial value - For cut bloom poor; landscape value poor. Variety as a whole poor.

\section{RUBICUNDA.}

Species - P. albiflora.

Origin unknown.

Donated by Chariton.

Description of bloom - Type of bloom bomb. Form of bloom tall, compact. Differentiated. Color (total effect) 3 ( $18 \mathrm{I}$ ) pure mauve; guards streaked light; 
collar same as guards; center clear; uniform color throughout. Yellow carpels, pink stigmas. Fragrance pleasant X. Blooming time mid-season. Medium size.

Description of plant - Habit of plant erect, medium tall, compact. Growth strong and healthy. Stem medium length, strong, green. Blooming habit free. Buds borne in clusters, healthy. Foliage well furnished, medium green, medium size; veins green.

Commercial value-For cut bloom medium; landscape value medium. Variety as a whole medium.

Remarks-This variety is entirely different from "Rubicunda Albomarginata" which is a dark red.

\section{STANDARD BEARER.}

Spccies - P. albiflora.

Originated by Hollis, I906.

Donated by Farr.

Description of bloom - Type of bloom bomb. Form of bloom globular, very compact. Differentiated. Entirely transformed. Color (total effect) violet rose I (I54); guards clear; collar same as guards; center slightly flecked with scarlet. Fragrance pleasant XX. Blooming time early to mid-season. Large size.

Description of plant - Habit of plant erect, medium tall, compact. Growth strong and healthy. Stem medium long, very strong, green. Blooming habit free. Buds borne in clusters. Foliage well furnished, medium to light green, medium to fine size; veins green.

Commercial iulue-For cut bloom extra good; landscape value good. Variety as a whole extra good.

\section{Red}

DANIEL D'ALBERT.

Species - P. albiflora.

Origin unknown.

Donated by Ellwanger \& Barry.

Description of bloom - Type of bloom bomb. Form of bloom globular, medium compact. Not clearly differentiated. Not entirely transformed. Color (total effect) tyrian rose $2-3$ ( 155 ) ; guards ciear; collar same as guards; uniform color. Smooth, green carpels; pink stigmas; silver tipped. Fragrance pleasant $\mathrm{X}$. Blooming time mid-season. Large size.

Description of plum -- Habit of plant medium erect, tall, medium compact. Growth strong and healthy. Stem long, strong, green. Blooming habit free. Buds borne in clusters, healthy. Foliage medium furnished, light green, medium size; veins green.

Commercial value - For cut bloom medium; landscape value medium. Variety as a whole medium.

Species - P. albitlora.

Originated by Hollis.

Donated by Hollis.

Description of bloom - Type of bloom bomb. Form of bloom globular, medium compact. Differentiated. Not entirely transformed. Color (total effect) 5 (I68) dark crimson; guards streaked light; center same; secondary staminodes absent. Smooth, yellow carpels, pink stigmas. Fragrance nearly lacking. Blooming time mid-season to late. Medium size. 
Description of plant - Habit of plant medium ercet, tall, medium compact. Crowth strong and healthy. Stem long, medium strong, reddish green. Blooming habit free. Lateral buds undeveloped, healthy. Foliage medium furnished, light green, fine; veins reddish green.

Commercial z'alut - For cut bloom poor; landscape value medium. Varicty as a whole medium.

\section{SOUVENIR DE L'EXPOSITION DE BORDEAUX.}

Species - P. albiflora.

Originated by Dessert, 1896.

Donated by Kline.

Description of bloom - Type of bloom bomb. Form of blonm glolular, medium compact. Differentiated. Not entirely transformed. Color (total effect) 4 (I80) reddish violet; guards clear; center clear. Bloom has only slight silver tip, does not fade much in the sunlight. Fragrance unpleasant X. Blooming time mid-season. Medium to small size.

Description of plant - Habit of plant medium erect, medium tall, medium compact. Growth medium to strong, healthy. Stem medium long, medium strong, red. Blooming habit free. Buds borne in clusters, healthy. Foliage well fus nished, dark green, fine; veins red.

Commercial zalue - For cut bloom medium; landscape value extra good. Variety as a whole good to extra good.

Species - P. albiflora.

TRAGEDY.

Originated by Hollis, 1908.

Donated by Farr.

Description of bloom - Type of bloom bomb. Form of bloom globular, merlium compact to loose. Differentiated. Entirely transformed. Color (total effect) dark crimson 5 ( I78); guards splashed light; collar same as guards; center clear. Very brilliant, dark variety, distinct shade. Fragrance pleasant X. Blooming time mid-season. Medium size.

Description of flant-Habit of plant erect, tall, compact. Growth strong. Stem medium long, medium to strong, reddish green. Blooming habit free. Lateral buds undeveloped, healthy. Foliage medium furnished, light green, medium size; veins reddish green.

Commercial zalue - For cut bloom good; landscape value good. Variety as a whole good.

Species - P. albiflora.

WASHINGTON:

Originated by Guerin, 1850 .

Donated by Dessert.

Description of bloom - Type of bloom bomb. Form of bloom flat, medium compact. Differentiated. Not entirely transformed. Color (total effect) I ( I55) tyrian rose; collar lighter than guards; tinted cream at the base; center I (r54) violet rose and silver tipped, clear. Yellowish carpels, pink stigmas. Same color as "General Bertrand" but more silver tipped. Fragrance pleasant XX. Blooming time mid-season. Medium size.

Description of plant - Habit of plant erect, medium tall, medium compact. Growth strong and healthy. Stem medium long, strong, red. Blooming habit medium. Buds borne in clusters, healthy. Foliage medium furnished, dark green, medium size; veins red.

Commercial zaluc - For cut bloom poor: landscape value poor. Varicty as a whole poor. 


\section{SEMI-ROSE TYPE}

\section{ALSACE LORRAINE.}

\section{White}

Spccies - P. albiflora.

Originatcd by Lemoine, 1906.

Donated by Farr.

Description of bloom - Type of bloom semi-1ose. Form of bloom flat, compact. Not differentiated. Not entirely transformed. Color (total effect) cream white I (I0), guards splashed slightly with crimson, collar same color as guards, center clear. Very attractive bloom. Fragrance unpleasant X. Blooming time late. Size large to very large.

Description of plant-Habit of plant medium erect, tall, medium compact. Growth strong, healthy. Stem long, medium strong, reddish green. Blooming habit free. Buds borne in clusters, healthy. Foliage medium furnished, medium green, medium size; veins red.

Commercial z'aluc - For cut bloom extra good; landscape value good. Variety as a whole extra good.

\section{AURORE.}

Species - P. albiflora.

Originated by Dessert, 1904.

Donated by Cottage Gardens Company and Shaylor and Farr.

Description of bloom - Type of bloom semi-rose. Form of bloom flat, loose.

Not differentiated. Not entirely transformed. Color (total effect) lilac white I (7), guards prominently 'flccked with crimson; collar milk white, lighter than guards; center flecked with crimson. The very center of the bloom is of the same shade as guards. Stamens very prominent, shown as well as in "La Rosiere" or "Marguerite Gérard." Fragrance pleasant X. Blooming time late. Large size.

Description of plant - Habit of pant erect, medium tall, compact. Growth strong, healthy. Stem medium long, strong, reddish green. Blooming habit free. Buds have laterals undeveloped, healthy. Foliage well furnished, medium green, fine in size; veins green.

Commercial value - For cut bloom good; landscape value good. Variety as a whole good.

Rcmarks-This variety should not be confused with "Aurora" (Pleas), see Bulletin 278, page 237, nor "Aurora" (Hollis), see page 78 .

\section{BOULE DE NEIGE.}

Species - P. albiflora.

Originated by Calot, 1862.

Donated by Cottage Gardens Company.

Description of bloom - Type of bloom, semi-rose. Form of bloom medium globular, medium compact. Not differentiated. Not entirely transformed. Color (total effect) milk white; guards flecked noticeably crimson; collar same as guards: center flecked crimson, very striking. Fragrance unpleasant $\mathrm{X}$. Blooming time early to mid-season. Very large to large size.

Description of plant - Habit of plant erect, tall, medium compact. Growth strong and healthy. Stem long, strong, reddish green. Blooming habit free. Buds borne in clusters, healthy. Foliage well furnished, dark green, coarse; veins green.

Commercial zalue - For cut bloom extra good; landscape value good. Variety as a whole good.

Remarks-Very similar to "Mons. Dupont," slightly more double, clearer white, and blooms $5-6$ days ahead of "Dupont." 


\section{CLARA BARTON.}

Specics-P. albiflora.

Originated by Terry

Donated by Cottage Gardens Company and Farr.

Description of bloom - Type of bloom semi-rose. Form of bloom globular, loose. Not differentiated. Not entirely transformed. Color (total effect) milk white; guards prominently flecked with crimson; center clear. Green carpels, pink stigmas. Bloom is single in weak plants. Fragrance unpleasant $\mathrm{X}$. Blooming time early. Size large.

Description of plant-Habit of plant drooping, medium height, open. Growth medium. Stem medium long, weak, red. Blooming habit medium. Buds borne in clusters, healthy. Foliage medium furnished, medium green, fine; veins red.

Commercial value - For cut bloom poor; landscape value poor. Variety as a whole poor.

\section{JAMES KELWAY.}

Specics - P. albiflora.

Originated by Kelway.

Donated by' Cottage Gardens Company.

Description of bloom - Type of bloom semi-rose. Form of bloom flat, loose.

Not differentiated. Not entirely transformed. Color (total effect) I (8) rose white; guards prominently flecked with crimson; collar lighter than guards, fades milk white; center clear, central parts have yellow veins toward base.

Fragrance unpleasant $\mathrm{X}$. Blooming time mid-season. Very large size.

Description of plant - Habit of plant medium erect, medium hcight, mexlium compact. Growth medium to strong, healthy. Stem medium long to long, medium strong, reddish green. Blooming habit free. Buds borne in clusters, healthy. Foliage well furnished, light green, medium size; veins green.

Commercial value - For cut bloom good; landscape value good. Variety as a whole good.

Remarks - Came from Peterson Nursery as such. Identical with "Lady Derby" from Shaylor and Thurlow, and "Mrs. Gwyn-Lewis" from Farr.

\section{LE CYGNE.}

Species - P. albiflora.

Originated by. Lemoine, I907.

Donated by Farr.

Description of bloom - Type of bloom semi-rose. Form of bloom globular, compact. Not differentiated. Not entirely transformed. Color (total effect) pure milk white; collar same as guards; center clear. A few yellow stamens in center of bloom. Fragrance pleasant XX. Mid-season. Large size.

Description of plant-Habit of plant, erect, medium tall to tall, medium compact. Growth strong and healthy. Stem medium long, strong. Blooming habit medium frec. Buđs borne in clusters, healthy. Foliage well furnished, dark green, medium size; veins reddish green.

Commercial value-For cut bloom good; landscape value extra good to good. Variety as a whole good.

Remarks - The globular, compact type of hloom of this variety makes it easily distinguishable from other varieties. 


\section{MADAME DE TRÉYÉRAN.}

Spccies - P. albiflora.

Originated by Dessert, 1899 .

Donated by Farr.

Description of bloom - Type of bloom semi-rose. Form of bloom flat, compact.

Not differentiated. Not entirely transformed. Color (total effect) rose white

I (8); guards splashed with scarlet; collar same as guards; center flecked with crimson. Color is splashed on giving a rose white tint. Very attractive.

Fragrance pleasant XXX. Blooming time early. Size very large.

Description of plant - Habit of plant erect, medium tall, compact. Growth strong.

Stem medium long, strong, red. Blooming habit very free. Buds borne in clusters, healthy. Foliage medium furnished, medium green, medium to fine in size; veins reddish green.

Commercial salut - For cut bloom good; landscape value extra good. Varicty as a whole good.

\section{MARIE.}

Species - P. albiflora.

Originated by Calot, 1868 .

Donated by Farr.

Description of bloom-Type of hloom semi-rose. Form of bloom flat, compact.

Not differcntiated. Not entirely transformed. Color (total effect) lilac white fading to milk white 2 (7); guards flecked with crimson; collar same as guards; center clear. Golden yellow 2 (I6) staminodes, or short, narrow petals around the collar. Petals shading to yellow at base. Fragrance pleasant. Blooming time late. Medium size.

Description of plant-Habit of plant medium erect to erect, very tall, medium compact. Growth strong and healthy. Stem long, strong, reddish green. Blooming habit free. Buds borne in clusters. Foliage medium furnished, dark green, medium size; veins red.

Commercial ialue-For cut bloom good; landscape value good. Variety as a whole good.

Species - P. albiflora.

\section{USONA,}

Donated by Hollis.

Description of bloom - Type of bloom semi-rose. Form of bloom flat, medium compact. Not differentiated. Not entirely transformed. Color (total effect) lilac white I (7); guards flecked with crimson and green; center milk white, flecked. Stamens visible at center. Fragrance unpleasant XX. Blooming time mid-season. Very large size.

Description of plant - Habit of plant medium erect, medium tall, medium compact. Stem strong and healthy. Stem long, strong, green. Blooming habit free. Buds borne in clusters, healthy. Foliage well furnished, dark green, coarse; veins green.

Commercial z'aluc - For cut bloom poor; landscape value good. Variety as a whole good.

\section{MADEMOISELLE DESBUISSONS.}

\section{Pink and White}

Specics - P. albiflora.

Originated by Crousse, 1893 .

Donated by Goos and Koenemann.

Description of bloom - Type of bloom semi-rose. Form of bloom flat, compact. 


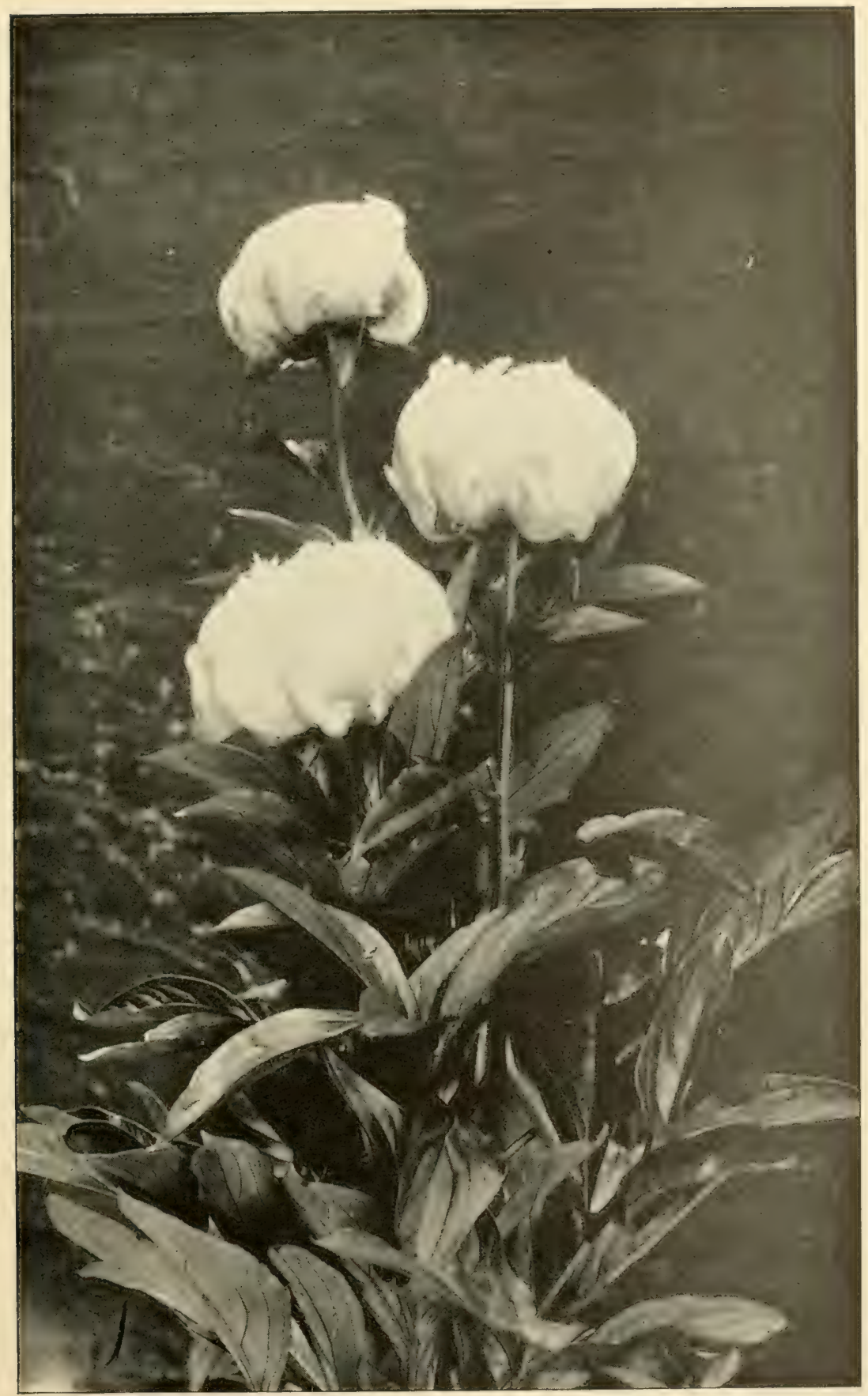

Marie Jacquin (semi-double type) 

Not differentiated. Not entirely transformed. Color (total effect) pink and white; guards violet rose I (I54); guards clear; center fades to milk white, clear. Stamens visible at center, small hairy carpels, white stigmas. Fragrance pleasant $X$. Blooming time mid-season. Large size.

Description of plant - Habit of plant erect, tall, compact. Growth strong and healthy. Stem long, strong, reddish green. Blooming habit very free. Buds borne in clusters, healthy. Foliage well furnished, medium green, coarse; veins reddish green.

(o)mercial abluc - For cut bloom meilium; landscape value extra good. Variety as a whole good.

\section{ARSÈNE MEURET.}

\section{Pink}

Spccics - P. albiflora.

Donated by Farr.

Description of bloom - Type of bloom semi-rose. Form of bloom glubular, medium compact. Not differentiated. Not entirely transformed. Color (total effect) violet rose I (I54); guards violet rose, flecked with green, streaked light; collar same as guards; center clear; bloom silver tipped. Fragrance unpleasant XX. Blooming time mid-season. Large size.

Describlion of plant - Habit of plant medium erect, medium tall, medium compact. Growth strong, healthy. Stem medium long, medium strong, reddish green. Blooming habit free. Buds borne in clusters, healthy. Foliage medium furnished, medium green, medium to fine size; veins green.

Commercial ia!uc - For cut bloom medium; landscape value good. Variety as a whole medium to good.

\section{BATTLEFIELD.}

Species-P. albiflora.

Originated by Hollis.

Donated by Hollis.

Description of bloom - Type of bloom semi-rose. Form of bloom flat, compact. Not differentiated. Not entirely transformed. Color (total effect) pure mauve 4 (I8I); guards flecked with crimson and green, splashed; center clear; secondary staminodes absent; silver-tipped imbricated bloom, uniform throughout. Fragrance unpleasant XX. Blooming time mid-season. Large size.

Description of plant - Hahit of plant drooping, tall, open. Growth strong, healthy. Stem long, strong, reddish green. Blooming habit medium. Buds borne in clusters. Foliage poorly furnished, dark green, coarse; veins reddish green. Commercial salue - For cut bloom medium; landscape value poor. Variety as a whole medium to poor.

Remarks - Drooping habit makes it undesirable.

\section{BÉLISAIRE.}

Specics - P. albiflora.

Originated by Lemoine, 1907 .

Donated by Farr.

Description of bloom-Type of bloom semi-rose. Form of bloom globular, medium compact. Not differentiated. Not entirely transformed. Color (total effect) pale lilac; guards very finely splashed with crimson; collar same as guards; center flecked with crimson. Splashed with minute dots of leeper illac. Fragrance umpleasant $\mathrm{X}$. Blooming time mid-season. Size medium to large. 
Description of plant - Habit of plant medium erect, medium tall, medium compact. Growth strong and healthy. Stem medium length, medium strong, red. Iluoming habit free. Buds borne in clusters, healthy. Foliage medium furnished, light green, medium size; veins red.

Commercial value - For cut bloom good; landscape value good. Variety as a whole good.

Remarks-Bloom is identical with "Asa Gray," the only difference in the two varieties being that "Bélisaire" has red stems, "Asa Gray" green.

\section{BLANCHE DESSERT.}

Species - P. albiflora.

Originated by Dessert, 1888 .

Donated by Farr.

Description of bloom - Type of bloom semi-rose. Form of bloom flat, medium compact. Not differentiated. Not entirely transformed. Color (total effect) solferino red 2 (I57); guards clear; collar same as guards; center clear. Bloom attractive, somewhat imbricated. Fragrance unpleasant $\mathrm{X}$. Blooming time early. Medium size.

Description of plant-Habit of plant drooping, medium tall, open. Growth medium, healthy. Stem medium length, weak, red. Blooming habit medium. Lateral buds undeveloped. Foliage poorly furnished, dark green, fine; veins reddish green.

Commercial value - For cut bloom poor; landscape value medium to poor. Variety as a whole medium to poor.

Remarks - Wiry, weak stems, poorly furnished.

\section{CARMEN.}

Species - P. albiflora.

Originated by Lemoine, 1898 .

Donated by Farr.

Description of bloom - Type of bloom semi-rose. Form of bloom flat, compact.

Not entirely differentiated. Not entirely transformed. Color (total effect)

hydrangea pink I (I32); guards clear; collar same as guards; center flecked with crimson. Color sprinkled on in fine dots like "Asa Gray." Fades lilac white. Fragrance unpleasant X. Blooming time mid-season. Very large size. Description of plant-Habit of plant erect, tall, medium compact. Growth strong and healthy. Stem long, strong, red. Blooming habit medium. Buds single, healthy. Foliage medium furnished, light green, medium size; veins reddish green.

Conmerial zalue - For cut bloom good; landscape value good. Variety as a whole good.

Species-P. albiflora.

\section{CERISETTE.}

Donated by Farr.

Description of bloom - Type of bloom semi-rose. Form of bloom flat, compact. Not differentiated. Not entirely transformed. Color (total effect) violet rose 3 (I54); guards clear; collar same as guards; center flecked with green at base occasionally. Fragrance unpleasant X. Blooming time early to midseason. Large size. 
Description of plant-IIabit of plant erect, medium tall, medium compact. Growth strong and heallhy. Stem medium long, medium strength, reddish green. Blooning habit nuclium. Luds borne in clusters. Foliage well furnished, medium green, medium size; veins red.

Commerid adul - lor cut bloum medium; landscape value medium. Variety as a whole medium.

\section{CHARLES TOCHÉ.}

Species-P. albiflora.

Originated by Dessert, I888.

Donaicd by Farr.

Description "f blenm - Type of bluom semi-double. Form of bloom globular, loose, stamens very noticeable. Not differentiated. Not entirely transformed. Color (total effect) violet rose 4 (154); guards clear; collar same as guards; center clear; color uniform. Fades in sun to I (I54). Fragrance unpleasant XX. Blooming time early. Medium size.

Description of plant-Habit of plant erect, dwarf, compact. Growth strong and healthy. Stem short, strong, red. Blooming habit frce. Buds borne in clusters, healthy. Foliage well furnished, medium to dark green, medium size; veins reddish green.

Commercial value - For cut bloom poor; landscape value good. Variety as a whole good.

\section{DUGUESCLIN.}

Spccies - P. albiflora.

Originatcd by Miellez, 185'\%.

Donated by Dessert.

Discriptiun of bloom - Type of bloom scmi-rose. Form of bloom globular, loose. Not differentiated. Not entirely transformed. Color (total effect) violet rose $4\left(\mathrm{I}_{54}\right)$; guards flecked with crimson; collar same as guards; center clear; secondary staminodes absent. Very prominently silver tipped. Petals noticcably scrrate. Fragrance unpleasant X. Blooming time mid-season. Size medium to large.

Description of plant - Habit of plant medium erect, medium height, compact. Growth medium, healthy. Stem medium long, medium strong, reddish green. Blooming habit free. Luls burnc in clusters, healihy. Foliage well furnished, medium green, medium size; veins reddish green.

Commercial value - For cut bloom poor; landscape value poor. Variety as a whole poor.

Specics - P. albiflora.

\section{ENCHANTMENT.}

Donated by Hollis.

Description of bloom - Type of blonm semi-rose. Form of blonm flat, medium compact. Not differentiated. Not entirely transformed. Color (total effect) pale lilac rose I ( 778$)$; guards clear; collar same as guards; uniform color; secondary staminodes absent. Bloom fades in sunlight to hydrangea pink. Stantens plainly visible. Fragrance umpleasant X. Blooming time mid-season. Medium size.

Description of plant - Halit of plant crooping, medium height, medium compact. Growth strong and healthy. Stem long, strong, green. Blooming habit medium. Buls borne in clusters, healthy. Foliage medium furnished, medium green, coarse; veins green.

Commential zaluc - For cut bloom poor; landscape value poor. Variety as a whole poor to worthless.

Remarks - Has no place in the trade. 


\section{EUGÉNIE VERDIER.}

Spccies - P. albifiora.

Originated by Calot, 1864 .

Donated by Farr.

Description of bioom - Type of bloom semi-rose. Form of bloom flat, medium compact to loose. Not differentiated. Not entirely transformed. Color (total effect) I (I32) hydrangea pink; guards clear; collar lighter than guards; very slight occasional crimson Hecks on center. Color fades to lilac white. Fragrance pleasant $\mathrm{X}$. Blooming time mid-season. Large size.

Description of plant - Habit of plant medium erect, tall, open. Growth strong and healthy. Stem long, medium strong, reddish green. Blooming habit free. Buds borne in clusters, healthy. Foliage medium furnished, medium green, medium size; veins red.

Commercial ralue - For cut bloom good; landscape value medium. Variety as a whole good.

Remarks - Much confused with "Eugene Verdier" and "Pottsi Alba."

\section{GÉÉRAL CAVAIGNAC.}

Species - P. albiflora.

Originated by Calot, 1858.

Donated by Farr.

Description of bloom - Type of bloom semi-rose. Form of bloom globular, compact. Not clearly differentiated. Entirely transformed. Color (total effect) light violet rose I (I54); guards clear; collar same as guards; center splashed with crimson. Bloom tipped light. Fragrance pleasant X. Blooming time late. Size very large.

Description of plant-Hahit of plant erect, tall, compact. Growth medium. Stem long, medium strong, green. Blooming habit free. Buds borne in clusters, healthy. Foliage medium furnished, light grecn, fine; veins green.

Commercial value - For cut bloom good; landscape value good. Variety as a whole good.

\section{GEORGIANA SHAYLOR.}

Species - P. albiflora.

Originated by Shaylor, I908.

Donated by Shaylor.

Description of bloon - Type of bloom semi-rose. Form of bloom globular, compact. Not differentiated. Not entirely transformed. Color (total effect) I (129) pale rose pink: guards flecked with crimson, splashed slightly with crimson; collar same as guards; center flecked with crimson. First class certificate at Massachusetts Horticultural Society I908. Fragrance pleasant X. Blooming time mid-season to late. Large size.

Description of plant - Habit of plant erect, medium tall, compact. Growth strong and healthy. Stem medium long, strong, reddish green. Blooming habit free. Buds borne in clusters, healthy. Foliage well furnished, medium size; veins green.

Commercial z'alue - For cut bloom good: landscape value good. Variety as a whole good. 
JAMES BLANC.

Species - P. albiflora.

Donated by Cottage Gardens Company.

Dcscription of bloom-Type of bloom semi-rose. Form of bloom flat, compact. Not differentiated. Not entirely transformed. Color (total effect) violet rose 3 (I54); guards clear; collar sime as guards; center clear. The distinguishing characteristic is decply notched petals throughout bloom of about same width. Fragrance lacking. Blooming time mid-season. Large size.

Description of plant - Habit of plant erect, medium height, compact. Growth strong and healthy. Stem medium long, strong, reddish green. Blooming habit medium. Buds borne in clusters, healthy. Foliage well furnished, dark green, coarse; veins green.

Commercial value - For cut bloom good; landscape value good. Variety as a whole good.

\section{MADAME BARILLET DESCHAMPS.}

Species - P. albiflora.

- Originated by Calot, 1868 .

Donated by Farr.

Description of bloom!-Type of bloom semi-rose. Form of bloom flat, imbricated. Not differentiated. Not entirely transformed. Color (total effect) violet rose 3 (I54); guards clear; collar same as guards; center flecked occasionally with scarlet on edge. Bloom fades to a delicate silver pink in the sun. Fragrance pleasant X. Blooming time early to mid-season. Large size.

Description of phunt-- Hahit of plant medium erect, medium height, medium compact. Growth strong and healthy. Stem medium long, strong, reddish green. Blooming habit medium. Buds borne in clusters, healthy. Foliage well furnished, light green, coarse; veins reddish green.

Commercial c'aluc - For cut bloom good; landscape value good. Variety as a whole good to extra good.

Species - P. alb:flora.

MARY L. HOILIS.

Donated by Hollis.

Description of bluom-Type of bloom semi-rose. Form of bloom flat, medium compact. Not differentiated. Not entirely transformed. Color (total effect) pale lilac rose 2 ( 178$)$; guards clear; center clear, fades lilac white; secondary staminodes absent. Yellow stamens, plainly visible at center, concealed at collar. Fragrance unpleasant XX. Blooming time mid-season. Large size.

Description of plant-Habit of plant erect, tall, compact. Growth strong and healthy. Stem long, strong, green. Blooming habit free. Buds borne in clusters, healthy. Foliage well furnished, medium green, coarse; veins green.

Commerial ialu-lior cut bloom medium; landscape value extra good. Variety as a whole good.

Remarks-A very attractive bloom.

Specics - P. albiflora.

NOBILISSIMA.

Donated by Cottage Gardens Company.

Originated by Miellez, 1858 .

Description of bloom - Type of blonm semi-rose. Form of bloom flat, medium compact. Not differentiated. Not entirely transformed. Color (total effect) 
4 (I54) violet rose; guards clear; collar same as guards; center flecked with crimson. Fragrance umpleasant X. Blooming time mid-season to late. Large size.

Description of plant - Habit of plant erect, tall, medium compact. Growth strong and healthy. Stem long, strong, reddish green. Blooming habit free. Buds borne in clusters, healthy. Foliage medium furnished, dark green, medium size; veins red.

Commercial value-For cut bloom medium; landscape value good. Variety as a whole good.

\section{PETER PAN.}

Species - P. albiflora.

Originated by Hollis.

Donatcd by Hollis.

Description of bloom - Type of bloom semi-rose. Form of bloom flat, loose. Not differentiated. Not entirely transformed. Color (total effect) lilac rose I (I52); guards flecked crimson; center prominently flecked crimson, fades lighter than guards. Bloom fades in sun to lilac white. Fragrance unpleasant $\mathrm{X}$. Blooming time mid-season. Large size.

Description of plant-Habit of plant erect, medium height, compact. Growth strong and healthy. Stem long, strong, green. Blooming habit free. Buds borne in clusters, healthy. Foliage well furnished, medium green, medium size; veins green.

Commercial ialue - For cut bloom poor; landscape value good. Variety as a whole medium.

Species-P. albiflora.

PRAIRIE SPLENDOR.

Donated by Farr.

Description of bloom - Type of bloom semi-rose. Color (total effect) 2 (154) violet rose; guards clear; collar same as guards; center slightly flecked with crimson. Bloom silver tipped. Stamens may entirely disappear on very strong plants. Fragrance lacking. Blooming time mid-season. Large size.

Description of plant-Habit of plant erect, tall, medium compact. Growth strong and healthy. Stem long, medium strong, red. Blooming habit free. Buds borne in clusters, healthy. Foliage medium furnished, medium green, medium size; veins red.

Commercial value - For cut bloom good; landscape value good. Variety as a whole good.

Species - P. albiflora.

\section{REINE HORTENSE.}

Donated by Farr.

Description of bloom - Type of bloom semi-rose. Form of bloom flat, compact. Slightly differentiated. Not entirely transformed. Color (total effect) hydrangea pink 2 ( 132 ); guards splashed with crimson; collar same color as guards; center prominently flecked with crimson. Color splashed nn rose white background. Fades in sunlight. Fragrance pleasant X. Blooming time early to mid-season. Very large size.

Description of piant- Habit of plant erect, tall, medium compact. Growth strong and healthy. Stem long, strong, reddish green. Blooming habit medium. Buds borne in clusters. Foliage medium furnished, medium to dark green, medium size; veins reddish green.

Commcrcial z'alue-For cut bloom good; landscape value medium. Variety as a whole good. 


\section{RUY BLAS.}

Species - P. albiftora.

Originated by Dessert.

Donated by Farr.

Description of bloom - Type of bloom semi-rose. Form of bloom flat, medium compact. Not differentiated. Not entirely transformed. Color (total effect) pure mauve 3 (18I) ; guards clear ; collar same as guards; center clear. Bluom fades rapidly, silver tipped. Fragrance unpleasant XXX. Blooming time midseason. Medium size.

Description of plant-Hahit of plant erect, dwarf, compact. Growth strong. Stem short, medium strong, reddish green. Blooming habit free. Buds borne in clusters, healthy. Foliage well furnished, light green, medium size; veins reddish green.

Commercial idulu - For cut bloom medium; landscape value good. Variety as a whole medium.

\section{SARAH BERNHARDT.}

Species - P. albiflora.

Originated by Lemoine, I906.

Donated by Farr.

Description of bluom-Type of bloom semi-rose. Form of hloom flat, imbricated, compact. Not differentiated. Not entirely transformed. Color (total effect) mauve rose 2 (I53) ; guards clear; collar same as guards; center clear. Bloom silver tipped. Fragrance pleasant X. Blooming time late. Size large to very large.

Discription of plant-Habit of plant medium erect, tall, medium compact. Growth strong. Stem long, medium strong, reddish green. Blooming habit free. Buds borne in clusters, healthy. Foliage medium furnished, medium green, medium size; veins green.

Commercial zalue-For cut bloom extra good; landscape value good. Varicty as a whole extra good.

Remarks - This variety should not be confused with the so-called "Sarah Bernhardt" (Dessert) which is really "Umbellata Rosea." See page 292, Bulletin 278 .

\section{TROJAN.}

Spccies - P. albiflora.

Origin unknown.

Donated by Farr.

Description of bloom - Type of bloom semi-rose. Form of bloom flat, medium compact. Not differentiated. Not entirely transformed. Color (total effect) crimson pink I ( I50); guards flecled with scarlet and green; collar same col r as guards; center slightly flecked with crimson and white; secondary staminodes'absent. Bloom silver tipped. Fragrance unpleasant XX. Blooming time mid-season. Medium to large size.

Description of plant-Hahit of plant erect, medium height, compact. Growth strong and healthy. Stem medium long, strong, reddish green. Blooming habit free. Buds borne in clusters, healthy. Foliage well furnished, dark green, medium size; veins green.

Commercial a'aluc - For cut bloom medium; landscape value good. Variety as a whole good. 


\section{WALTER FAXON.}

Species - P. albiflora.

Originated by Richardson.

Donated by Shaylor.

Description of bloom-Type of bloom semi-rose. Form of bloom globular, medium compact. Differentiated. Not entirely transformed. Color (total effect) bright rose 2 ( 128 ) ; guards clear; center clear; uniform color throughout. Guard petals fade lighter than center. Very delicate color. Fragrance slight. Blooming time mid-season. Medium size.

Description of plont-Habit of plant medium erect, medium tall, medium compact. Growth medium strong, healthy. Stem medium long, medium strong, grcen. Blooming habit medium to free. Foliage medium to dark green; veins reddish green.

Commercial zalue - For cut bloom good; landscape value medium. Variety as a whole good.

\section{ADMIRAL TOGO.}

\section{Red}

Species-P. albiflora.

Originated by Hollis, I907.

Donated by Farr and Hollis.

Description of bloom - Type of bloom semi-rose. Form of bloom flat, medium compact. Not differentiated. Not entirely transformed. Color (total effect) crimson carmine 6-7 (159); guards clear; collar same as guards; center clear. Holds colur well (no silver tips). Fragrance unpleasant XX. Blooming time mid-season. Size medium to large.

Description of plant-Habit of plant erect, medium tall, compact. Growth medium strong, healthy. Stem medium long, strong, reddish green. Blooming habit medium free. Buds borne in clusters, healthy. Foliage well furnished, very dark green, medium fine; veins red.

Commercial value - For cut bloom good; landscape value good. Variety as a whole good.

\section{AKSARBEN.}

Specics - P. albiflora.

Originated by Rosenfield, 1908.

Donated by Farr.

Description of bloom-Type of bloom semi-rose. Form of bloom flat, compact. Not differentiated. Not entirely transformed. Color (total effect) dark crimson 4-5 (I6S); guards clear; collar same as guards; center, green streaks in carpelodes. Fragrance unpleasant X. Blooming time mid-season. Size large.

Description of plant - Habit of plant erect, tall, medium compact. Growth strong, healthy. Stem long, strong, reddish grecn. Blooming habit free. Buds borne in clusters, healthy. Foliage medium furnished, dark green, medium fine; veins green.

Commercial value-For cut bloom good; landscape value good. Variety as a whole good.

Remarks-Somewhat like "Karl Rosenfield," but foliage not as coarse, bloom more compact, with green streaks in center. 


\section{AUGUSTE GAUTHIER.}

Species-P. albiflora.

Originated by Dessert and Mechin, I890.

Donated by Cottage Gardens Company.

Description of bloom - Type of bloum semi-rose. Form of hloom globular, mediuin compact. Not differentiated. Not entirely transformed. Color (total effect) tyrian rose 4 ( 155 ); guards clear; collar same as guards; center clear ; secondary staminodes absent. Nuticeably silver tipped, imbricated, wide petals throughout. Fragrance unpleasant XX. Blooming time mid-season. Large size.

Description of plant - Habit of plant erect, medium height, compact. Growth strong and healthy. Stem medium long, medium strength, red. Blooming habit free. Bucls bornc in clusters, healthy. Foliage well furnished, dark green, medium size; veins reddish green.

Commercial ialue - For cut bloom medium; landscape value good. Variety as a whole good.

Species - P. albiflora.

\section{BISMARK.}

Donated by Charlton.

Origin unknown.

Description of bloom - Type of bloom semi-double. Form of bloom flat, loose.

Not differentiated. Not entirely transformed. Color (total effect) magenta $4\left(I_{2}\right)$; guards clear; collar same as guards; center clear; secondary staminodes absent. Fragrance unpleasant XX. Blooming time mid-season. Large size.

Description of plant-Habit of plant crect, tall, medium compact. Growth strong and healthy. Stem long, medium strong, red. Blooming habit free. Buds borne in clusters, healthy. Foliage poorly furnished, medium to light green, fine; veins red.

Commercial zalue-For cut bloom poor; landscape value poor. Variety as a whole poor.

Rcmarks - Absolute identity is not established.

\section{CAVALLERIA RUSTICANA.}

Species - P. albiflora.

Originated by Kelway.

Donated by Farr.

Description of bloom - Type of bloom semi-rose. Form of bloom globular, medium compact. Not entirely differentiated. Not entirely transformed. Color (total effect) reddish violet 4 (I68); guards have light streak in center; collar same color as guards; center clear; uniform color. Wide petals throughout bloom. Fragrance unpleasant X. Blooming time mid-season. Large size. Description of plent - Habit of plant erect, medium tall, medium compact to compact. Growth strong and healthy. Stem medium long, strong, reddish green. Blooming habit free. Bucls borne in clusters, healthy. Foliage medium furnished, dark green, medium size; veins red.

Commercial value - For cut bloom good; landscape value good. Variety as a whole good.

Species - P. albiflora.

\section{COQUELIN.}

Donated by Farr.

Description of bloom - Type of bloom semi-double. Form of bloom flat, loose. Not differentiated. Not entirely transformed. Color (total effect) tyrian rose 
I (I55); guards clear; collar same as guards; center clear. Bloom becomes silver tipped with age. Stamens visible at collar and center. Fragrance unpleasant XX. Blooming time early. Medium size.

Description of plant - Habit of plant drooping, dwarf to medium, medium compact. Growth medium strong, healthy. Stem short to medium length, weak to medium strong, red. Blooming habit medium. Buds borne in clusters, healthy. Foliage medium furnished, medium green, medium size; veins red.

Commerciul salue - For cut bloom poor; landscape value medium. Variety as a whole medium.

\section{E. G. HILL.}

Species - P. albiflora.

Originated by Lemoine, 1906.

Donated by Farr.

Description of bloom-Type of bloom semi-rose. Form of bloom medium globular, compact. Slightly differentiated. Not entirely transformed. Color (total effect) tyrian rose 2 (I55); uniform color; center 2 (155), clear. Very showy, desirable bloom. Stamens nearly concealed. Fragrance unpleasant X. Blooming time early. Size large to very large.

Description of plant - Habit of plant erect, dwarf, compact. Growth strong and healthy. Stem short, strong, green. Blooming habit free. 'Lateral buds undeveloped, healthy Foliage medium furnished, medium green, medium size; veins green.

Commercul a'alue - For cut bloom good; landscape value extra good. Variety as a whole extra good.

\section{GÉNÉRAL DODDS.}

Species - P. albifiora.

Originated by Crousse, 1893 .

Donated by Farr.

Description of bloom - Type of bloom semi-rose. Form of bloom globular, very compact. Slightly differentiated. Entirely transformed. Color (total effect) dark tyrian rose 4 (I55); guards splashed with green; collar same as guards; center clear. A few small, pure white petals around the center. Fragrance lacking. Blooming time late. Size very large.

Descriplion of plant - Habit of plant erect, tall, compact. Growth strong. Stem long: strong, green. Blooming habit free. Buds borne in clusters, healthy. Foliage well furnished, medium to light green, medium size; veins green.

Commercial value-For cut bloom good; landscape value good. Variety as a whole good.

\section{GENERAL HOOKER.}

Species - P. albiflora.

Originated by Terry.

Donated by Farr

Description of bloom - Type of bloom semi-rose. Form of bloom flat, compact. Not differentiated. Not entirely transformed. Color (total effect) 4 (I55) tyrian rose; guards flecked; collar same as guards; center clear; uniform color throughout. Bloom has slight silver tip. Fragrance unpleasant XX. Blooming time mid-season. Size large.

Description of piant-Habit of plant medium ercet, medium tall to tall, medium compact. Growth medium to strong, healthy. Stem long, medium strong, reddish green. Blooming habit free. Buds borne in clusters, healthy. Foliage medium furnished, medium green, medium size; veins reddish green.

Commercial zalue-For cut bloom good; landscape value good. Variety as a whole good. 


\section{GEORGE WASHINGTON.}

Specics-P albiflora.

Originated by Hollis, I904.

Donatcel by Fiarr

Description of bloom - Type of bloom semi-rose. Form of bloom flat, loose. Not differentiated Not entirely transformed. Color (total effect) 4 (I68) dark crimson, guards clear, collar same as guards; center clear, uniform color. Fragrance unpleasant XXX. Blooming time mid-season. Large size.

Description of plant - Habit of plant erect, medium height, medium compact. Growth strong and healthy. Stem medium to long, strong, red. Blooming habit medium. Buds borne in clusters, healthy. Foliage well furnished, dark green, medium size; vens vivid red.

Commercial zalue - For cut bloom poor; landscape value medium. Variety as a whole medium.

Remarks-Much like numeraus other red semi-doubles. Not to be confused with "Washington" (Guerin, 1860).

\section{KARL ROSENFIELD}

Specics-P. albiflora.

Denated by Farr and Rosenfield.

Originated by Rosenfield, I908.

Description of bloom-Type of bloom semi-rose. Form of bloom globular, compact. Not differentiated. Not entirely transformed. Color (total effect) $4^{-5}$ (168) dark crimson; guards clear; collar same as guards; center clear. Fragrance lacking. Blooming time mid-season. Size large to very large.

Description of plant - Habit of plant erect, tall, compact. Growth strong and healthy. Stem long, strong. green. Blooming habit free. Buds borne in clusters. Foliage well furnished, dark green, coarse; veins green.

Commercial valuc - For cut bloom good; landscape value good. Variety as a whole very good Keeps unusually well as a cut flower. One of the best crimson varicties in the trade.

\section{MADAME ADRIEN SÉNÉCLAUZE.}

Strcies-P. albiflora.

Originated by Sénéclauze, I875.

Donated by Dessert.

Descriplion of bloom - Type of bloom semi-rose. Form of bloom flat, medium compact. Not differentiated. Not entirely transformed. Color (total effect) I (I69) rose magenta; guards streaked light; collar lighter than guards; center clear; secondary staminodes absent. Bloom fades somewhat on tips with age. Fragrance unpleasant XX. Blooming time mid-season. Large size.

Description of plant-Habit of plant medium erect, tall, medium compact. Growth strong and healthy. Stem long, strong, reddish green. Blooming habit free. Buds borne in clusters, healthy. Foliage well furnished, light green, coarse, veins reddish green.

Commercial zalue-For cut bloom poor; landscape value medium. Variety as a whole medium. 


\section{MADAME AUGUSTE DESSERT.}

Species - P. albiflora.

Originated by Dessert, 1899.

Donated by Shaylor.

Description of bloom - Type of bloom semi-rose. Form of bleom medium globular, medium compact. Color (total effect) I (I54) violet rose; guards slightly flecked with crimson; collar same as guards; center flecked with crimson. Fragrance unpleasant XX. Blooming time early to mid-season. Very large to large size.

Description of plant - Habit of plant erect, medium height, compact. Growth strong and healthy. Stem medium long, strong, green. Blooming habit free. Buds borne in clusters, healthy. Iioliage well furnished, medium green, medium size; veins green.

Commercial value - For cut bloom good; landscape value good. Variety as a whole good.

\section{MADAME MOUTOT.}

Species - P. albiflora.

Originated by Crousse, 1892.

Donated by Farr.

Description of bloom - Type of bloom semi-rose. Color (total effect) 2 (I55) tyrian rose; guards clear; collar same as guards; center clear. Bloom fades slight silver tipped. Fragrance pleasant XX. Blooming time mid-season. Medium size.

Description of plant - Habit of plant erect, medium height, compact. Growth medium strong. Cornell specimens diseased. Stem medium long, medium strong, red. Blooming habit shy; this may be on account of disease. Buds single, blight. Foliage medium furnished, light green, medium size; veins vivid red.

Commercial vulue - For cut bloom medium; landscape value medium. Variety as a whole medium.

Species - P. albiflora.

Origin unknown.

Donated by Farr.

Description of blonm - Type of bloom semi-rose. Form of bloom globular, medium compact. Not differentiated. Not entirely transformed. Color (total effect) dark crimson; uniform color throughout 5 (168); center clear. Very deep, rich color. Fragrance unpleasant X. Blooming time mid-season to late. Medium size.

Description of plant-Habit of plant crect, medium height, compact. Growth strong and healthy. Stem medium long, strong, red. Blooming habit irregular. Buds borne in clusters. Foliage medium furnished, dark green, medium size; veins vivid red.

Commercial value - For cut bloom medium; landscape value good. Variety as a whole good.

\section{PIERRE REIGNOUX.}

Species - P. albiflora.

Originated by Dessert, 1908 .

Donated by Farr.

Description of bloom - Type of bloom semi-rose. Form of bloom medium flat, medium to compact. Not differentiated. Not entirely transformed. Color (total effect) tyrian rose I (I55); guards clear; collar I (I55) same as guards; center slightly flccked with crimson. Imbricated, very attractive 
bloom. Fades out in sun; a few stamens seen in center of bloom. Fragrance unpleasant X. Blooming time early. Large size.

Description of plant - llalit of plant mediuni crect to dronping, dwarf, medium compact. Growth medium strong, healthy. Stem short, medium strong to weak, red. Blooming habit medium to free. Lateral buds undeveloped. Foliage medium furnished, medium green, fine size; veins reddish green.

Commercial value - For cut bloom poor; landscape valuc good. Variety as a whole good.

\section{RAPHAEL.}

Species - P. albiflora.

Originated by Mechin, I882.

Donated by Farr.

Descriptiun of bloom - Type of bloom semi-rose. Form of bloom globular, medium compact to loose; stamens visible. Not differentiated. Not entirely transformed. Color (total effect) purple garnet 5-6 (I65); guards streaked light; center has occasionally light streak. Very desirable, dark red for early season. Fragrance unpleasant $\mathrm{X}$. Blooming time extra early. Medium size.

Description of plant - Habit of plant erect, dwarf, compact. Growth strong and healthy. Stem short, strong, vivid red. Blooming habit very free. Buds borne in clusters, healthy. Foliage well furnished, dark green, medium size; veins red.

Commercial calue - For cut bloom poor; landscape value good to extra good. Variety as a whole good.

Species - P. albiflora.

\section{ROSSINI.}

Donated by Farr.

Description of bloom-Type of bloom semi-rose. Form of bloom flat, imbricated, medium compact. Not differentiated. Not entirely transformed. Color (total effect) tyrian rose 4 (I55), silver tipped; guards clear; collar same as guards; center clear. Stamens are concealed; bloom fades quickly in the sun. Fragrance unpleasant XX. Blooming time early to mid-season. Medium size.

Description of plant - Halit of plant erect, medimm tall, medium compact. Growth strong and healthy. Stem medium length, medium strength, red. Blooming habit medium to free. Buds borne in clusters, healthy. Foliage medium furnished, dark green, medium size; veins red.

Commercial z'alue - For cut bloom medium to good; landscape value good. Variety as a whole good.

Species - P. albiflora.

\section{SAMOSET.}

Donated by Hollis.

Description of bloom-Type of bloom semi-rose. Form of bloom flat, medium compact to compact. Not differentiated. Not entirely transformed. Color (total effect) rose magenta I (I69); guards streaked light; center clear, slightly silver tipped. This is a showy bloom. Fragrance unpleasant XX. Blooming time early to mid-season. Very large size.

Description of plant - Habit of plant very erect, tall, compact. Growth strong and healthy. Stem 1ong, strong, red. Blooming habit free. Buds borne in clusters, healthy. Foliage well furnished, dark green, coarse; veins reddish green. Commercial za!ne - For cut bloom medium; landscape value extra good. Variety as a whole good.

Remarks - This is a very promising variety. 


\section{SENATOR.}

Species - P. albiflora.

Donated by Farr.

Description of bloom - Type of bloom semi-rose. Form of bloom flat, imbricated, medium compact. Not differentiated. Not entirely transformed. Color (total effect) reddish violet 4 ( 180$)$; guards streaked light; collar same as guards; center clear̈; secondary staminodes absent. A few stamens partly visible in the center of the bloom. Fragrance unpleasant XX. Blooming time early to mid-season; size very large.

Description of plant-Habit of plant medium erect to drooping, tall, medium to open. Growth strong and healthy. Stem long, medium strong to strong, reddish green. Blooming habit free. Buds borne in clusters, healthy. Foliage medium furnished, medium green, medium to coarse in size; veins reddish green.

Correction to Bulletin 259 - The above description is much better for this variety.

\section{TENIERS.}

Specics - P. albiflora.

Originated by Crousse, 1880.

Donated by Cottage Gardens Company.

Description of bloom - Type of bloom semi-rose. Form of bloom flat, medium compact. Not differentiated. Not entirely transformed. Color (total effect) purple garnet 5 (I65); guards streaked light; collar same as guards; center silver tipped, slightly streaked light; uniform color. Fragrance unpleasant $\mathrm{X}$. Blooming time mid-season. Mediuni size.

Description of plant-Habit of plant medium erect, medium tall to dwarf, compact. Growth strong and healthy. Stem medium long, strong, red. Blooming habit medium. Buds borne in clusters, healthy. Foliage well furnished, dark green, medium size; veins reddish green.

Commercial valuc - For cut bloom medium; landscape value good. Variety as a whole medium.

Correction to Bulletil 259-The above description is much better for this variety.

\section{White}

Specics-P. albiflora.

Originated by Kelway.

Donated by Farr, Shaylor, Rosenlield, Cottage Gardens Company, Perennial Gardens, Ellwanger \& Barry, Blue Hill Nursery.

Description of bloom - Type of bloom rose. Form of bloom globular, compact. Not differentiated. Not entirely transformed. Color (total effect) flesh white fading to milk white; guards clear; collar same as guards; center clear. Fragrance pleasant XX. Blooming time mid-season. Large size.

Description of plant - Habit of plant erect, tall, compact. Growth strong. Stem long, strong, reddish green. Free blooming. Lateral buds undeveloped, healthy. Foliage well furnished, medium green, medium size; green veins.

Commercial sulue - For cut bloom extra good; landscape value good. Variety as a whole extra good. 
Spccics - P. albiflora.

\section{CARNEA STRIATA.}

Donated by Jackson and Perkins.

Origin unknown.

Description of bloon - Type of bloom rose. Form of bloom globular, medium compact. Slightly differentiated. Entirely transformed. Color (total effect) lilac white; guards clear; collar same as guards; center flecked with crimson; secondary staminodes absent. Fragrance pleasant X. Blooming time midseason. Medium to large size.

Description of plunt - Habit of plant medium erect, meclium tall, medium compact. Growth strong and healthy. Stem medium long, medium strength, grcen. Blooming habit free. Buds borne in clusters, healthy. Foliage medium furnished, light green, fine; veins green.

Commercial z'alue-For cut bloom good; landscape value good. Variety as a whole good.

\section{CLAUDE GELÉE.}

Specics - P. albifiora.

Originated by Lemoine.

Donated by Farr.

Description of bloom - Type of bloom rose. Form of bloom flat, medium compact. Not differentiated. Entirely transformed. Color (total effect) I (Io) creamy white; guards clear; collar same as guards; center clear; secondary staminodes absent. Occasional faint crimson fleck on center petals. Fragrance pleasant X. Blooming time late. Size large.

Description of plunt-Habit of plant medium erect, dwari to medium compact. Growth medium strong, stem medium long, medium strong. Blooming habit medium. Buds single, occasional side buds. Foliage medium furnished, medium green, medium size; veins green.

Commercial zalue-For cut bloom good; landscape value good. Variety as a whole good.

Remarks - Color effect and type of bloom same as "Alsace Lorraine" but much more dwarf and a few days later.

\section{DOROTHY E. KIBBY.}

Species - P. albiflora.

Donated by Hollis.

Originated by Hollis, 190\%.

This so-called variety cannot be distinguished from "Couronne d'Or." Synonym - "Couronne d'Or."

Spccies - P. albiflora.

\section{EMMCHEN.}

Donated by Goos and Koenemann.

Description of bloom - Type of bloom rose. Form of bloom flat, medium compact. Not differentiated. Entirely transformed. Color (total effect) milk white; guards clear; collar same as guards; center clear; secondary staminodes present. Fragrance unpleasant $\mathrm{X}$. Blooming time late. Size large.

Description of plant-Hahit of plant erect, medium tall to tall, compact. Growth strong and healthy. Stem medium long, strong, green. Blooming habit free. Buds borne in clusters, healthy. Foliage well furnished, dark green, coarse; veins green.

Commercial value - For cut bloom good; landscape value good. Variety as a whole good. 


\section{ENCHANTRESSE.}

Species - P. albiflora.

Donated by Cottage Gardens Company.

Description of bloom - Type of bloom rose. Form of bloom globular, compact.

Not differentiated. Entirely transformed. Color (total effect) I (Io) creamy white; guards splashed with scarlet; collar same color as guards; center faintly flecked with crimson. Fragrance pleasant X. Blooming time very late. Very large size.

Description of plant-Habit of plant erect, tall, medium compact. Growth strong and healthy. Stem long, strong, green. Blooming habit free. Buds borne in clusters, healthy. Foliage well furnished, light green, medium size; veins green.

Commercial value - For cut bloom good; landscape value good. Variety as a whole good to extra good.

\section{GRANDIFLORA (RICHARDSON).}

Species - P. albiflora.

Originated by Richardson and Hovey, 1883.

Donated by Cottage Gardens Company and Farr.

Description of bloom - Type of bloom rose. Form of bloom flat, compact. Not differentiated. Entirely transformed. Color (total effect) 2 (7) rose white; guards clear; collar same as guards; center clear. Fragrance pleasant XX. Blooming time late. Very large size.

Description of plant - Habit of plant medium erect, tall, open. Growth strong and healthy. Stem long, medium strong, green. Blooming habit medium. Buds borne in clusters, healthy. Foliage medium furnished, medium green, medium to fine in size; veins red.

Commerciul z'aluc - For cut bloom good; landscape value good. Variety as a whole good.

\section{HUMEI ALBA.}

Spccies - P. albiflora.

Originated by Lemon, 1830.

Donated by Cottage Gardens Company.

Description of bloom-Type of bloom rose. Form of bloom flat, loose. Not differentiated. Entirely transformed. Color (total effect) lilac white I (7); guards clear; collar same as guards; center clear. Fragrance pleasant XX. Blooming time early. Large size.

Description of plant - Habit of plant medium erect, medium height, medium compact. Growth medium strong, healthy. Stem medium long, medium strong, green. Bloomit? habit medium. Buds borne in clusters, healthy. Foliage medium furnished, light green, fine; veins green.

Commcrial z'aluc - For cut bloom good: landscape value medium. Variety as a whole good.

\section{LADY DARMOUTH.}

Species - P. Albiflora.

Origin unknown, I850.

Donated by Farr.

Description of bloom-Type of bloom rose. Form of bloom flat, loose. Slightly differentiated. Entircly transformed. Color (total effect) milk white; guards clear; collar cream white; center flecked with green. Petals of all sizes mixed throughout bloom. Fragrance pleasant X. Blooming time early. Small size. 


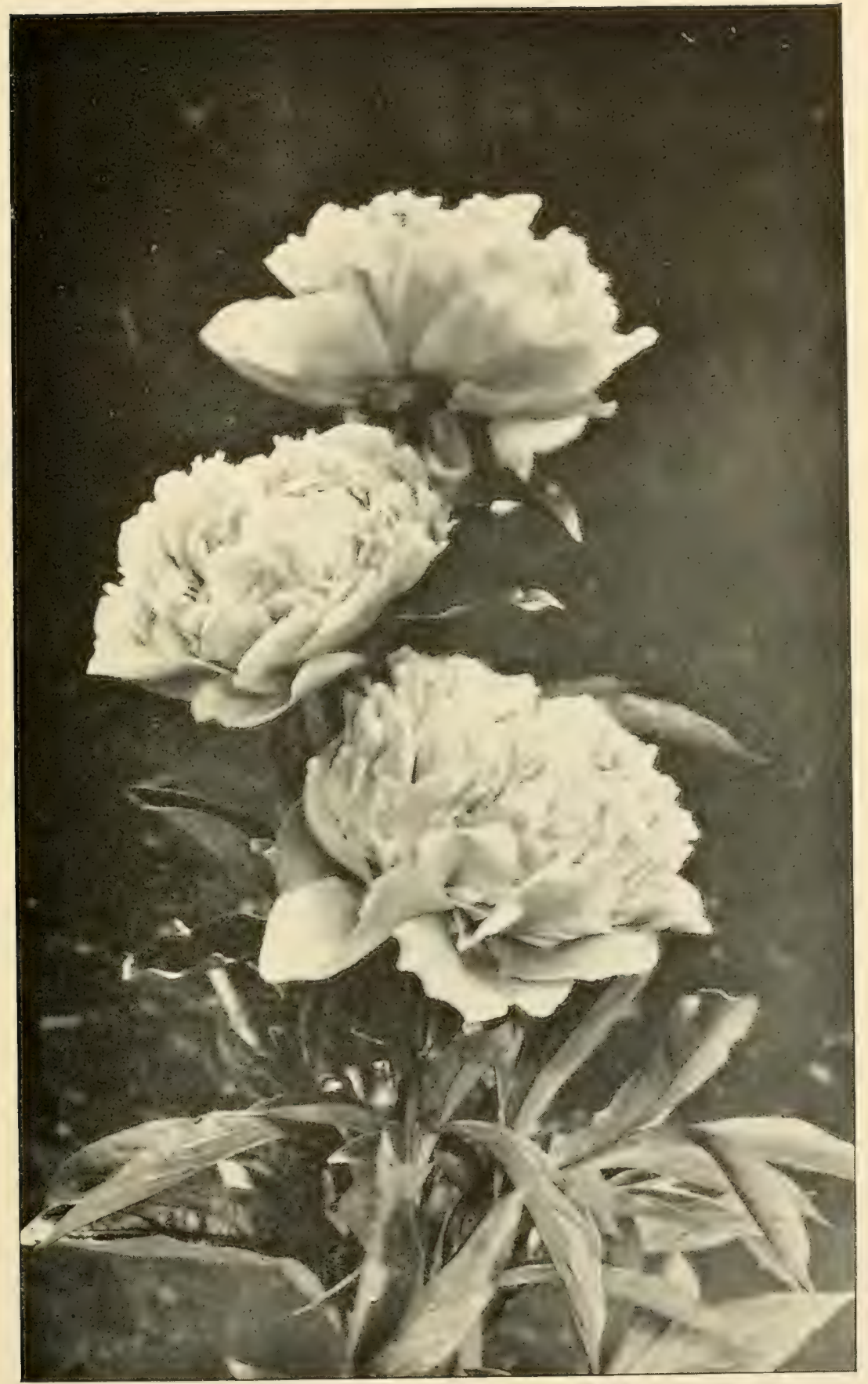

Lamartine (rose type as grown at the Cottage Gardens nurseries) 

Description of plant - Habit of plant erect, medium height, medium compact. Growth strong and healthy. Stem medium long, strong, redelish green. Blonming habit free. Buds borne in clusters. Foliage well furnished, medium green, medium size; veins reddish green.

Commercial ialue - For cut bloom poor; landscape value medium. Variety as a whole medium.

\section{LA FRANCE.}

Species-P. albiflora.

Originated by Lemoine, I90I.

Donated by Farr.

Description of bloom - Type of bloom rose. Form of bloom globular, compact.

Not differentiated. Entirely transformed. Color (total effect) rose white 3 (8) ; guards splashed with crimson; collar same as guards; center clear; bloom uniform color throughout; secondary staminodes absent. The outer guard petals have a splash of crimson through the center deepening at the base. Fragrance very pleasant XX. Blooming time mid-season to late. Very large size.

Description of plant - Habit of plant erect, medium tall to tall, compact. Growth strong and healthy. Stem long, strong, reddish green. Blooming habit free. Buds borne in clusters, healthy. Foliage medium furnished, medium green, medium size; veins reddish green.

Commercial ialue - For cut hloom extra good; landscape value extra good. Varicty as a whole extra good.

Remarks - Very distinct variety. Perfect rose type.

\section{LA TENDRESSE.}

Species - P. albiflora.

Originated by Crousse, 1896.

Donated by Farr.

Description of bloom - Type of bloom rose. Form of bloom flat, compact. Not differentiated. Entirely transformed. Color (total effect) milk white; guards slightly splashed; center flecked with crimson. Flecks are very prominent on some blooms, very slight on others. Fragrance pleasant X. Blooming time early. Size medium to large.

Description of plant - Habit of plant erect, medium tall, medium compact to open. Growth medium strong, healthy. Stem medium long, medium strong to strong, reddish green. Blooming habit free. Buds borne in clusters. Foliage medium furnished; medium green, medium size; veins reddish green.

Commercial zalu - For cut bloom extra good; landscape value good. Variety as a whole good.

Species - P. albiflora.

\section{LUCY E. HOLLIS.}

Donated by Hollis.

Description of bloom - Type of bloom rose. Form of bloom flat, compact. Not differentiated. Entirely transformed. Color (total effect) lilac white I (7); guards clear; collar same as guards; center slightly flecked with scarlet; secondary staminodes present. Center of bloom shaded to pale lilac rose I ( I78). Fragrance pleasant X. Blooming time very late. Large size.

Description of plant - Habit of plant drooping. not good, medium height, merlium compact. Growth strong and healthy. Stem medium long, medium strong to 
weak, green. Blooming habit free. Buds borne in clusters, healthy. Foliage well furnished, medium green, coarse; veins green.

Commercial valut-For cut bloom medium; landscape value poor. Variety as a whole medium to poor.

Remarks - Undesirable bud like "Charlemagne."

\section{MADAME ÉMILE GALLÉ.}

Species - P. albiflora.

Originated by Crousse, $188 \mathrm{I}$.

Donated by L. Paillet.

Descriplion of hloom-Type of bloom rose. Form of bloom flat, compact. Not differentiated. Color (total effect) 2 (7) lilac white; guards clear; center clear; secondary staminodes present. Fine formed, attractive bloom, center fades with age to milk white. Fragrance pleasant X. Blooming time midseason to late. Large size.

Descriplion of plunt - Habit of plant medium erect, medium tall to tall, compact. Growth strong and healthy. Stem long, strong, green. Blooming habit free. Buds borne in clusters, healthy. Foliage well furnished, medium to light green, medium size; veins reddish green.

Commercial zalue - For cut bloom extra good; landscape value good. Variety as a whole good to extra good.

Correction to Bulletin 259 - The above description is much better for this variety.

\section{MADAME FOULD.}

Species - P. albiflora.

Donatcd by Cottage Gardens Company.

Originated by Crousse, 1893 .

liscription of bloom - Type of bloom rose. Form of bloom globular, compact.

Not differentiated. Entirely transformed. Color. (total effect) milk white; guards clear; center lilac white, very slightly flecked with crimson. Fragrance pleasant X. Blooming time very late. Large size.

Description of plant - Habit of plant erect, tall, compact. Growth strong and healthy. Stem long, very strong, green. Blooming habit medium. Buds borne in clusters, healthy. Foliage medium furnished, medium green, coarse; veins green.

Commercial r'ahe - For cut bloom good; landscape value good. Variety as a whole good.

Femarks - Very tight bud, too full; apt to burst and become waterlogged.

\section{MADAME VILMORIN.}

Species - P. albiflora.

Originated by Guerin, 1866.

Donatcd by Farr.

Descrition of bloom - Type of bloom rose. Form of bloom only medium globular. Not differentiated. Entirely transformed. Color (total effect) rose white 2 (8) ; guards clear; collar same as guards; center splashed with rose. Bloom shading to amber at base of petals. Occasional narrow petals intermixed. Fragrance very pleasant XX. Blooming time late. Medium size.

Description of plant - Hahit of plant medium erect, medium height, medium compact. Growth medium strong. Stem medium long, medium strong, green. 
Blooming habit free. Buds borne in clusters, healthy. Foliage medium furnished, medium green, medium size; veins red.

Commercial value-For cut bloom good; landscape value good. Variety as a whole good.

\section{MADEMOISELLE MARIE CALOT.}

Spccies-P. albiflora.

Originated by Calot, 1872.

Donated by Farr, Coltage Gardens Company, and Goos and Koenemann.

Description of bloom - Type of bloon rose. Form of bloom globular, medium compact. Not difierentiated. Entirely transformed. Color (total effect) milk white; guards clear; center usually slightly flecked with crimson. Very poor, loose blooms are produced until clump is well established for 4-5 years. Fragrance pleasant XX. Blooming time mid-season. Large size.

Description of plant-Habit of plant erect, medium height, compact. Growth strong. Stem medium long, strong, green. Blooming habit free. Buds borne in clusters, healthy. Foliage well furnished, dark green, coarse; veins reddish green.

Conneribl aulue-For cut bloom medium; landscape value medium. Variety as a whole medium.

\section{MARIE DEROUX.}

Species - P. albiflora.

Originated by Crousse, I88I.

Donatcd by Cottage Gardens Company.

Description of bloom-Type of bloom rose. Form of bloom flat, medium compact. Not differentiated. Entirely transformed. Color (total effect) lilac white 2 ( $(7)$; guards prominently flecked with crimson; collar lighter than guards; center clear. Fragrance pleasant X. Blooming time late. Large size.

Description of plunt - Habit of plani medium erect, tall, open. Growth strong and healthy. Stem long, medium strong, reddish green. Blooming habit medium. Buds borne in clusters, healthy. Foliage medium furnished, medium green, medium size; veins reddish green.

Commercial sulue - For cut bloom medium; landscape value medium. Variety as a whole medium.

\section{MARY A. LIVERMORE.}

Sfecies-P. albifiora.

Originated by Hollis, I907.

Donated by Hollis.

Descriftion of bum - Type of bloom rose. Form of bloom flat, medium compact.

Not differentiated. Entirely transformed. Color (total effect) milk white; guards slightly flecked crimson, clear; collar same as guards; center clear; secondary staminodes present. Fragrance pleasant X. Blooming time late. Large size.

Descriptien of plunt - Habit of plant medium erect, medium tall to tall, compact. Growth strong and healthy. Stem long, strong, reddish green. Blooming habit medium. Buds borne in clusters, healthy. Foliage medium furnished, dark green, coarse; veins red.

Commercial value - For cut bloom good; landscape value good. Variety as a whole good. 


\section{MONT BLANC.}

Spciics - P. albiflora.

Donated by Cottage Gardens Company.

Originated by Lemoine, 1899 .

Description of bloom-Type of bloom rose. Form of bloom globular, compact. Not differentiated. Entirely transformed. Color (total effect) milk white; guards slightly flecked with crimson; collar same as guards; center clear, slight rose white tint. Blooms larger than "Festiva Maxima." One of the very best varieties in the trade. Very distinct and much superior to the "Mont Blanc" ("Solfatare") which is usually found under this name. Fragrance pleasant XXX. Blooming time early to mid-season. Very large size.

Description of plant - Habit of plant erect, medium height, compact. Growth strong and healthy. Stem medium long, very strong, reddish grcen. Blooming habit free. Buds borne in clusters, healthy. Foliage medium furnished, dark green to medium green, coarse; veins green.

Commercial ialue - For cut bloom extra good; landscape value extra good. Variety as a whole extra good.

Species-P. albiflora.

PARADISE.

Donated by Hollis.

Discription of bloom-Type of bloom rose. Form of bloom flat, medium compact. Not differentiated. Entirely transformed. Color (total effect) lilac white; guards hydrangea pink I (I32); guards slightly streaked; center occasionally flecked, fades milk white; secondary staminodes present. Fragrance pleasant $\mathrm{X}$. Blooming time early to mid-season. Large size.

Description of plant-l labit of plant medium erect, medium tall, compact. Growth strong and healthy. Stem medium long, strong, reddish green. Blooming habit free. Buds borne in clusters, healthy. Foliage well furnished, dark green, medium size; veins reddish green.

Commercial ialue-For cut bloom good; landscape value good. Variety as a whole good.

Species - P. albiflora.

\section{SNOWBALL.}

Donated by Hollis.

Description of bloom-Type of bloom rose. Form of bloom flat, medium compact. Not differentiated. Entirely transformed. Color (total effect) milk white; guards slightly splashed; collar same color as guards; center clear, milk white; secondary staminodes present. Fragrance pleasant X. Blooming time mid-season. Small size.

Description of plant - Habit of plant medium erect, dwarf, compact. Growth strong and healthy. Stem medium long to short, medium strong to weak, reddish green. Blooming habit medium. Buds borne in clusters, healthy. Foliage well furnished, dark green, fine; veins reddish green.

Commercial ialue - For cut bloom poor; landscape value poor. Variety as a whole worthless.

Species - P. albiflora.

Originated by Hollis, 1907.

Donated by Hollis.

Description of bloom - Type of bloom rose. Form of bloom medium globular, medium compact. Not differentiated. Entirely transformed. Color (total effect) milk white; guards slightly splashed; collar same color as guards; 
center clear; secondary staminodes present. Very undesirable bud; worse than "Charlemagne." Fragrance pleasant XX. Blooming time very late. Medium size.

Description of plant - Habit of plant erect, medium tall, compact. Growth strong, diseased. Stem medium long, strong, green. Blooming habit medium to shy. Buds borne in clusters, blighted. Foliage will furnished, dark green, medium size; veins green.

Commercial value - For cut bloom poor; landscape value poor. Variety as a whole poor to worthless.

\section{Pink and White}

Species - P. albiflora.

Originated by Hollis, I907.

Donated by Hollis.

Description of blowm - Type of bloom rose. Form of bloom glohular, medium compact. Not differentiated. Entirely transformed. Color (total effect) pale rose pink; guards I (7) lilac white, flecked with crimson; collar same as guards; center I (I29) pale rose pink, clear; secondary staminodes present. Very attractive, full double bloom. Fragrance pleasant X. Blooming time very late. Large size.

Description of plant-Habit of plant erect, medium height, compact. Growth strong and healthy. Stem medium long, strong, green. Blooming habit free. Buds borne in clusters, healthy. Foliage medium furnished, medium green, medium size; veins green.

Commercial a'due-For cut bloom good; landscape value good. Variety as a whole good.

Species - P. albiflora.

\section{HAPPY DAY.}

Donated by Hollis.

Descriplion of bloom - Type of bloom rose. Form of bloom flat, medium compact. Not differentiated. Entirely transformed. Color (total effect) pink and white; guards 4 (I54) violet rose, streaked; center lilac white, prominently flecked and streaked with crimson; secondary staminodes present. Bloom fades. Fragrance pleasant X. Blooming time mid-season. Very large size.

Description of plant-Habit of plant erect, tall, compact. Growth strong and healthy. Stem long, strong, reddish green. Blonming habit free. Buds borne in clusters, healthy. Foliage medium furnished, dark green, coarse; veins reddish green.

Commercial z'alue - For cut bloom good: landscape value good. Variety as a whole good.

Species - P. albiflora.

\section{QUEEN EMMA.}

Donated by Wild.

Description of bloom - Type of bloom rose. Form of bloom flat, compact. Not differentiated. Entirely transformed. Color (total effect) pale lilac rose and cream; guards pale lilac, flecked with green; collar cream white and lilac; center clear; secondary staminodes present. Entire bloom is intermixed with cream petals. Fragrance pleasant X. Blooming time mid-season. Size medium. 
Description of plant - Habit of plant erect, medium tall, compact. Growth strong and healthy. Stem medium long, medium strong, green. Blooming habit free. Buds borne in clusters, healthy. Foliage well furnished, medium green, fine; veins reddish green.

Commerciul idulue - For cut bloom medium; landscape value good. Variety as a whole medium to good.

\section{Pink}

\section{AUGUSTE VILLAUME.}

Species - P. albifiora.

Originated by Crousse, 1895 .

Donated by Farr.

Description of bloom - Type of bloom rose. Form of bloom globular, compact. Not differentiated. Entirely transformed. Color (total effect) violet rose 4 (I54); uniform color throughout; guards clear, collar same as guards; center clear. Very full, extra large bloom with a few short narrow petals near the center. Not a first-class bud. Fragrance pleasant X. Blooming time late. Large size.

Description of plant-Habit of plant erect, tall, medium compact. Growth strong. Stem long, strong, reddish green. Blooming habit free. Buds borne in clusters, healthy. Foliage well furnished, medium green, coarse to medium in size; veins red.

Commcrcill value - For cut bloom good; landscape value good. V'ariety as a whole good.

\section{BELLE DOUAISIENNE.}

Species - P. albiflora.

Donated by Farr.

Description of bloom - Type of bloom rose. Form of bloom globular, compact. Color (total effect) hydrangea pink I (132); guards clear; center prominently flecked with crimson. Uniform color. Fades to lilac white. Fragrance pleasant XX. Blooming time mid-season. Large size.

Description of plant-Habit of plant drooping, medium height, open. Growth strong, healthy. Stem long, strong, reddish green. Blooming habit free. Buds borne in clusters. Foliage medium to poorly furnished, medium green, coarse; veins reddish green.

Commercial value - For cut bloom good; landscape value poor. Variety as a whole medium.

Specics - P. albiflora.

Origin unknown.

Donated by Charlton.

Description of bloom - Type of bloom rose. Form of bloom globular, compact. Not differentiated. Entirely transformed. Color (total effect) violet rose I (I54); guards clear; collar same as guards; center flecked; secondary staminodes absent. Intermixed with linear petals. Fragrance pleasant XX. Blooming time mid-season. Size large.

Description of plant-Habit of plant medium erect, medium to tall, compact. Growth strong and healthy. Stem medium to long, strong, green. Blooming habit free. Buds borne in clisters, healthy. Foliage well furnished, medium to light green, medium size; veins green to reddish green.

Commcrial value-Extra good for cut bloom; landscape value good. Variety as a whole good.

Remarks - Identity questionable. 


\section{BELLE MAUVE.}

Species - P. albiflora.

Originated by Lemoine, 1903.

Donated by Farr.

Description of bloom - Type of bloom rose. Form of bloom flat, medium compact. Slightly differentiated. Entirely transformed. Color (total effect) pale lilac rose I-4 (I30); guards clear; collar same as guards; center clcar. Uniform color. Fades to noticeable silver tip. Fragrance pleasant XXX. Blooming time mid-season. Large size.

Description of plant-Habit of plant medium erect to tall, medium compact. Growth strong, healthy. Stem long, strong, red. Blooming habit free. Buds borne in clusters, healthy. Foliage medium furnished, light green, medium size; veins red.

Commercial a'alue-For cut bloom medium; landscape value medium. Variety as a whole medium.

\section{BERANGER.}

Species - P. albiflora.

Originated by Dessert, I895.

Donated by Cottage Gardens Company.

Description of bloom - Type of bloom rose. Form of bloom very flat, medium compact. Color (total effect) violet rose 2 (I54); guards clear; collar same as guards; center clear. Fragrance pleasant XX. Blooming time very late. Medium size.

Description of plant-Habit of plant erect, tall, compact. Growth strong and healthy. Stem long, medium strength, reddish green. Biooming habit medium. Buds borne in clusters. Foliage medium furnished, dark green, coarse; veins reddish green.

Commercial value - For cut bloom good; landscape value good. Varicty as a whole good.

\section{CARNEA ELEGANS.}

Species - P. albiflora.

Originated by Guerin, I850.

Donated by Farr.

Description of bloom - Type of bloom rose. Form of blonm flat, medium compact. Not differentiated. Entirely transformed. Color (total effect) hydrangea pink I (I32); guards clear; collar same as guards; center clear. Red stigmas. Fragrance pleasant XXX. Blooming time mid-season. Size small to medium.

Description of plant - Habit of plant medium erect, medium tall, medium compact. Growth medium strong. Stem medium long, medium strong, green. Blooming habit free. Buds borne in clusters. Foliage medium furnished, light green, medium size; veins green.

Commercial value - For cut bloom good; landscape value good. Variety as a whole good.

Remarks-This varicty should not be confused with "Carnea Elegans" (Calot), Bulletin 278, page 262 .

Correction to Bullctin 2/8-The description in the above pulplication is the Calot sort and not Guerin's as printed. 
Species - P. albiflora.

\section{CHARIOTTE CUSHMAN.}

Donated by Hollis.

Description of bloom - Type of bloom rose. Form of bloom globular, compact. Not differentiated. Entirely transformed. Color (total effect) solferino red I (I57); guards flecked; center clear. Color uniform. Secondary staminodes present. Fragrance pleasant X. Blooming time late. Size large.

Description of plunt - Habit of plant medium erect, tall, medium compact. Growth strong and healthy. Stem long, strong, reddish green. Blooming habit medium. Buds borne in clusters, healthy. Foliage medium furnished to poor, light green, coarse; veins green.

Commerciul iulue-lior cut bloom medium; landscape value poor to medium. Variety as a whole medium.

\section{CHRISTINE RITCHER.}

Species - P. albiflora.

Originated by Hollis, 1907 .

Donated by Hollis.

Description of bloom - Type of bloom rose. Form of bloom globular, compact.

Not differentiated. Entirely transformed. Color (total effect) 2 (I54) violet rose; guards slightly flecked; center clear; color uniform throughout; secondary staminodes present. Fragrance unpleasant X. Elooming time late. Size medium to small.

Description of plant - Habit of plant medium to erect, medium height, compact. Growth strong and healthy. Stem medium long, strong, reddish green. Blooming habit free. Buds borne in clusters, healthy. Foliage well furnished, light green, coarse; veins reddish green.

Commercial saluc - For cut bloom medium; landscape value good. Variety as a whole medium to good.

\section{CLAIRE DUBOIS.}

Species - P. albiflora.

Originated by Crousse, 1886.

Donated by Farr.

Description of bloom - Type of bloom rose. Form of bloom globular. Not differentiated. Entirely transformed. Color (total effect) 4 (I54) violet rose; guards clear; collar same as guards; center clear; secondary staminodes absent. The petals are tipped silvery white. Fragrance unpleasant. Blooming time late. Size very large.

Description of plant-Habit of plant erect, tall, compact. Growth strong. Stem long, strong, green. Blooming habit medium. Buds borne in clusters, healthy. Foliage medium furnished, medium green, medium size; veins green.

Commercial iduc-For cut hloom extra good; landscape value extra good. Variety as a whole extra good.

Species - P. albiflora.

\section{CLARA HERSEY.}

Donated by Hollis.

Originated by Hollis, 1907 .

Descriplion of blonm - Type of bloom rose. Form of bloom flat, medium compact. Not differentiated. Entirely transformed. Color (total effect) 4 (I54) violet rose; guards clear; collar same as guards; center clear; secondary staminodes present. Fragrance pleasant X. Blooming time mid-season. Medium size. 
Description of plant-Habit of plant drooping, medium tall, medium compact. Growth medium, healthy. Stem medium long, weak, reddish green. Blooming habit medium. Buds borne in clusters, healthy. Foliage medium furnished, dark green, medium size; veins.reddish green.

Commercial adalue - lior cut bloum pour; landscape value poor. Variety as a whole poor.

Remarks - Not very attractive.

\section{CONQUERER.}

Species - P. albiflora.

Originated by Hollis, 1907 .

Donated by Hollis.

Description of bloom-Type of bloom rose. Form of bloom flat, compact. Not differentiated. Entirely transformed. Color (total effect) lilac rose I (I52); guards streaked light; collar same as guards; center clear; secondary staminodes present. Bloom fades somewhat in sun. Fragrance pleasant X. Blooming time mid-season. Large size.

Description of plunt--Habit of plant erect to medium erect, very tall, medium compact. Growth strong and healthy. Stem long, strong, reddish green. Blooming habit free. Buds borne in clusters, healthy. Foliage medium furnished, medium green, coarse; veins green.

Commercial salue - For cut bloum medium; landscape value good. Variety as a whole medium to good.

\section{DUKE OF DEVONSHIRE.}

Species - P. albiflora.

Originated by Kelway, $\mathbf{8 9 6 6 .}$

Donated by Cottage Gardens Company.

Description of bloom - Type of bloom rose. Form of bloom flat, compact. Differentiated. Not entirely transformed. Color (total effect) solferino red 3 (157); guards clear; collar same as guards; center clear; uniform color. Narrow petals found scattered through the bloom. Fragrance pleasant X. Blooming time late. Size very large.

Description of plant-Habit of plant erect, tall, compact. Growth strong and healthy. Stem long, strong, reddish green. Blooming habit free. Buds borne in clusters, healthy. Foliage well furnished, medium green, medium size; veins reddish green.

Commcrial alue - For cut bloom medium; landscape value extra good. Variety as a whole good.

\section{EDMOND ABOUT.}

Species - P. albiflora.

Originated by Crousse, 1885 .

Donatcd by L. Paillet.

Description of bloom - Type of bloom rose. Form of bloom globular, compact. Not differentiated. Entirely transformed. Color (total effect) hydrangea pink I (I32); guards hydrangea pink; center a tint darker than the guards; some blooms very prominently flecked with crimson. Extra well made bloom. Fragrance pleasant XX. Blooming time mid-season to late. Size large.

Description of plant- Habit of plant medium to erect, medium tall, compact. Growth strong and healthy. Stem medium long, very strong, green. Blooming habit medium. Buds borne in clusters, healthy. Foliage well furnished, medium green, medium size; veins green. 
Commerciul s'aluc-For cut bloom good; landscape value good. Variety as a whole good.

Remurk - This variety secmed to thrive much better at Cornell than under the average nursery conditions elsewhere. In fact many growers have found this a very poor bloomer.

\section{ETTA.}

Specics - P. albiflora.

Originated by Terry.

Donatcd by Farr and Thurlow.

Description of bloom - Type of bloom rose. Form of bloom flat, medium compact to loose. Not differentiated. Entirely transformed. Color (total effect) hydrangea pink I (I32); guards clear; collar same as guards; center clear; uniform color. Fragrance pleasant XX. Blooming time very late. Size medium.

Description of plunt - Habit of plant medium erect to drooping, medium height, medium compact. Growth medium, healthy. Stem medium long, medium to weak, green. Blooming habit medium to shy. Lateral buds undeveloped, blight. Foliage medium furnished, medium to light green, fine; veins green.

Commerciul culuc-For cut bloom good; landscape value medium. Variety as a whole nedium to good.

\section{GOODSPEED.}

Species - P. albiflora.

Originated by Hollis, I907.

Donaled by' Hollis.

Description of bloom - Type of bloom rose. Form of bloom flat, medium compact. Not differentiated. Entirely transformed. Color (total effect) 4 (154) violet rose; guards clear; collar same as guards; center clear; uniform color throughnut. Blom silver tipped. Fragrance pleasant X. Blooming time midseason. Medium size.

Description of plant-Habit of plant erect, tall, compact. Growth strong and healthy. Stem long, weak, reddish green. Blooming habit medium. Lateral bucls undereloped, healthy. Foliage medium to poorly furnished, dark green, fine; veins reddish green.

Commercial ralue - For cut bloom poor; landscape value poor. Variety as a whole poor.

\section{HENRI MURGER.}

Species - P. albiflora.

Originated by Crousse, 1895 .

Donated by Farr.

Description of bloom - Type of bloom rose. Form of bloom globular, compact. Not differentiated. Entirely transformed. Color (total effect) I (I8I) pure mauve; guards clear; collar same as guards; center clear; secondary staminodes absent. Fragrance pleasant XX. Blooming time late. Size very large,

Descriftion of plant - Halit of plant erect, medium height, compact. Growth strong and healthy. Stem medium long, strong, green. Blooming habit free. Buds single, healthy. Foliage medium furnished, medium green, medium size; veins green.

Commerciul salue - For cut bloom good; landscape value good. Variety as a whole good. 


\section{IRMA.}

Spccies - P. albiflora.

Donated by Farr.

Originated by Calot, 1859 .

Description of bloom - Type of bloom rose. Form of bloom globular, compact.

Not differentiated. Entirely transformed. Color (total effect) violet rose 3 (I54); guards clear; collar same as guards; center clear; secondary staminodes absent. A few cream yellow, small petals at the center. Fragrance lacking. Blooming time late. Very large size.

Description of plant - Habit of plant erect, medium height, compact. Growth strong. Stem medium long, very strong, green. Blooming habit free. Buds borne in clusters. Foliage well furnished, light green, coarse; veins green. Commercial ralue-For cut bloom good; landscape value good. Variety as a whole good.

\section{JESSIE K. CROSBY.}

Species-P. albifiora.

Originated by Hollis, 1907.

Donated by Hollis.

Description of bloom - Type of bloom rose. Form of bloom tall, compact. Differentiated. Entirely transformed. Color (total effect) hydrangea pink, fades to lilac white; collar same as guards; center same; secondary staminodes present. Bloom is intermixed with narrow petals. Center forms hollow, cupshaped. Fragrance pleasant X. Blooming time mid-season. Medium size.

Description of plant - Habit of plant, erect, tall, compact. Growth strong and healthy. Stem very long, strong, reddish grcen. Blooming habit free. Buds borne in clusters, healthy. Foliage medium furnished, light green, coarse; veins reddish green.

Commercial value-For cut bloom poor; landscape value medium. Variety as a whole medium to poor.

\section{KELWAY'S QUEEN.}

Specirs - P. albiflora.

Originated by Kelway.

Donated by Farr.

Description of bloom - Type of bloom rose. Form of bloom globular, compact. Not differentiated. Entirely transformed. Color (total effect) mauve rose ? (I53) ; guards clear; collar same as guards; center flecked with crimson; secondary staminodes present. Fragrance pleasant X. Blooming time mid-season to late. Large size.

Description of plant - Habit of plant erect, tall, compact. Growth strong. Stem long, strong, reddish green. Blooming habit free. Lateral buds undeveloped, healthy. Foliage well furnished, medium green, medium size: veins red.

Commercial value - For cut bloom good; landscape value extra good. Variety as a whole extra good. This is distinct from "The Queen" (Kelway).

\section{LOST TREASURE.}

Species - P. albiflora.

Originated by Pleas (?)

Donatcd by Pleas.

Description of bloom - Type of bloom rose. Form of bloom flat, compact. Not differentiated. Entirely transformed. Color (total effect) violet rose 2 (I54); guards flecked with green; collar same color as guards; center occasionally flccked crimson; uniform color throughout. Very attractive, well formed, delicate bloom. Center fades to lilac white. Fragrance pleasant X. Blooming time mid-season. Size large to very large. 
Description of plant - Habit of plant medium erect, medium height, compact. Growth strong and healthy. Stem medium long, strong, reddish green. Blouming habit free. Buds borne in clusters, healthy. Foliage well furnished, medium to light green, medium size; veins reddish green.

Commercial zalue - For cut bloom good; landscape value good. Variety as a whole good.

\section{LOVELINESS.}

Species - P. albiflora.

Originated by Hollis, 1907.

Donated by Hollis.

Discription of bloom - Type of bloom rose. Form of bloom flat, medium conpact. Not differentiated. Color (total effect) I (I32) hydrangea pink fading to lilac white; guards clear; uniform color throughout; secondary staminodes present. Fragrance pleasant X. Blooming time mid-season. Size medium.

Description of plant-Habit of plant erect, medium tall, medium compact. Growth strong and healthy. Stem medium long, strong, reddish green. Blooming habit medium. Buds borne in clusters, healthy. Foliage medium furnished, dark green, coarse; veins red.

Commercial zalue - For cut bloom medium; landscape value good. Variety as a whole good.

\section{LUCIE MALARD.}

Species - P. albiflora.

Originated by Crousse, 1879.

Donated by Dessert.

Description of bloom - Type of bloom rose. Form of bloom globular, compact. Not differentiated. Entirely transformed. Color (total effect) 3 (I54) violet rose; guards flecked with green; collar same as guards; center clear; secondary staminodes present. Fragrance pleasant XX. Blooming time mid-season. Large size.

Description of plant-Habit of plant medium erect, tall, medium compact. Growth strong and healthy. Stem long, strong, green. Blooming habit free. Buds borne in clusters, healthy. Foliage medium furnished, light green, coarse; veins green.

Commercial zalu-For cut bloom good; landscape value good. Variety as a whole good.

\section{MADAME MUYSSART.}

Specics - P. albiflora.

Originated by Calot, 1869.

Donated by Cottage Gardens Company.

Description of bloom - Type of bloom rose. Form of bloom flat, very compact. Not differentiated. Entirely transformed. Color (total effect) I (157) solferino red; guards streaked light; center clear; uniform color throughout; secondary staminodes present. Bloom is silver tipped. Fragrance pleasant X. Blooming time late. Very large size.

Description of plant-Habit of plant erect, medium tall to tall, compact. Growth strong and healthy. Stem long, strong, green. Blooming habit free. Buds borne in clusters, healthy. Foliage well furnished, dark green, medium size; veins green.

Commercial i'alue - For cut bloom good; landscape value good. Variety as a whole good. 


\section{MARCHIONESS OF LANSDOWNE.}

Species-P. albiflora.

Originated by Kelway.

Donated by Farr.

Description of bloom - Type of bloom rose. Form of bloom flat, compact. Not differentiated. Entirely transformed. Color (total effect) I (I32) hydrangea pink; guards clear; collar same as guards; center flecked slightly with crimson; secondary staminodes present. Full, double, imbricated flower, shaded somewhat darker in the center. Fragrance pleasant X. Blooming time midseason. Large size.

Description of plant - Habit of plant mediun erect, medium height, medium compact. Growth strong and healthy. Stem medium long, medium strong, red. Blooming habit free. Buds borne in clusters, healthy. Foliage medium furnished, medum green, medium size; veins reddish green.

Commerciul zalue - For cut bloom good; landscape value good. Variety as a whole good.

\section{MARMONTEL.}

Species - P. albiflora.

Originated by Crousse, 1898 .

Donated by Minot.

Description of bloom - Type of bloom rose. Form of bloom globular, compact. Not differentiated. Entirely transformed. Color (total effect) I (I54) violet rose; guards clear; center clear. Bloom is silvery tipped. Fragrance pleasant X. Blooming time late. Medium to large size.

Description of plant-Habit of plant erect, medium height, compact. Growth strong. Cornell specimens diseased. Stem medium long to long, medium strong, reddish green. Blooming hahit medium. Buds borne in c'usters, slight blight. Foliage medium furnished, dark green, fine; veins reddish green. Commerciul s'alue - For cut bloom medium; landscape value medium. Variety as a whole medium.

\section{MAUD L. RICHARDSON.}

Species - P. albiflora.

Originated by Hollis.

Donated by Hollis.

Description of bloom-Type of bloom rose. Form of bloom fiat, medium compact. Not differentiated. Entirely transformed. Color (total effect) pale lilac rose 2 ( 178$)$; guards clear; center clear, fades lighter than guards; secondary staminodes present. Remnants of anthers concealid on petals around collar Fades to hydrangea pink. Fragrance pleasant XX. Blooming time late. Medium to large size.

Description of plant-Halbit of plant drooping, tall, medium compact. Growth strong, healthy. Stem long, strong, reddish green. Blooming habit medium. Buds borne in clusters, healthy. Foliage medium furnished, medium to light green, medium size; veins reddish green.

Commercial salue - For cut bloom good: landscape value medium to poor. Variety as a whole medium.

MILTON HILL.

Species - P. albiflora.

Originated by Richardson.

Donated by Shaylor.

Description of bloom - Type of bloom rose. Form of bloom globular, compact. 
Not differentiated. Entirely transformed. Color (total effect) I (I30) pale lilac rose; guards clear; collar same as guards; center clear. Very distinct, pure color. Fragrance lacking. Blooming time late. Very large size.

Description of plant - Habit of plant drooping, medium height, medium compact.

Growth strong. Stem medium long, medium strength, green. Blooming habit medium. Buds borne in clusters. Foliage medium furnished, light green, medium size; veins green.

Commorcial s'aluc - For cut bloom good; landscape value medium. Variety as a whole good.

Synonym - "Augustus Gould."

\section{MONSIEUR BARRAL.}

Species - P. albiflora.

Originated by Calot, I866.

Donated by Jackson \& Perkins, and Farr.

Description of bloom - Type of bloom rose. Form of bloom flat, compact. Not differentiated. Entirely transformed. Color (total effect) pale lilac rose I (I30) ; guards clear; collar same as guards; center clear. Same color as "Livingstone"; fades silver tipped. Fragrance pleasant XXX. Blooming time late. Very large size.

Description of plant-- Habit of plant somewhat drooping, tall, open. Growth strong and healthy. Stem long, strong, reddish green. Blooming habit free. Buds borne in clusters, healthy. Foliage poorly furnished, light green, medium size; veins reddish green.

Commercial value - For cut bloom good; landscape value good. Variety as a whole good.

\section{MONSIEUR HIPPOLYTE DELILLE.}

Spccies - P. albiflora.

Donated by Croux et Fils.

Originated by Calot, 1872

Description of bloom - Type of bloom rose. Form of bloom flat, medium compact. N'ot differentiated. Entirely transformed. Color (total effect) pale lilac rose I (I78), fading in center nearly white; guards clear; collar same as guards; center clear; uniform color; only a few secondary staminodes present. A very attractive bloom. Fragrance pleasant XX. Blooming time late. Large size.

Description of plant-Habit of plant medium erect, medium dwarf, compact. Growth strong and healthy. Stem medium long, medium strong, green. Blooming habit medium. Lateral buds undeveloped, slight blight. Foliage well furnished, dark green, medium size; veins reddish green.

Commorcial vilue - For cut bloom medium; landscape value medium. Variety as a whole medium.

\section{ROSA BONHEUR.}

Species - P. albiflora.

Originated by Dessert.

Donated by McKissock.

Description of bloom - Type of bloom rose with wide, imbricated petals. Form of bloom flat. Color (total effect) violet rose I (154); guards prominently flecked with crimson; collar same color as guards; center clear; secondary staminodes absent. Fragrance pleasant. Blooming time mid-season. Very large size. 
Description of plant - Habit of plant erect, meditm tall, compact. Giruth surung and healthy. Stem medium length, strong, reddish grecn. Blooning habit free Buds borne in clusters. Foliage well furnished, medium green, medium size; veins red.

Commercial zalue - For cut bluom goud; landscape value extra good. Variety as a whole good to extra good.

Specics - P. albiflora.

\section{SPEEDWELL.}

Donated by Hollis.

Description of blonm-Type of bloom rose. Form of bloom flat, compact. Not differentiated. Entirely transformed. Color (total effect) I (I57) solferino red; guards clear; uniform color throughout; secondary staminodes present. Cream white, narrow petals concealed throughout the bloom. Fragrance pleasant X. Blooming time mid-season. Medium size.

Descriphon of plant-Habit of plant medium erect, medium tall to tall, compact. Growth medium strong, healthy. Stem medium long, medium strong, redclish green. Blooming habit medium. Buds borne in clusters, blight. Foliage medium furnished, dark green, fine; veins reddish green.

Commercial ialue - For cut bloom poor; landscape value poor. Variety as a whole poor.

Remarks-Very similar to "Docteur Bretonneau" (Verdier), but rather inferior to it.

\section{SULLY PRUDHOMME.}

Species-P. albiflora.

Donated by Farr, and De Graaf Brothers.

Description of bloom - Type of bloom rose. Form of bloom flat, medium compact to loose. Not differentiated. Entirely transformed. Color (total effect) I (I32) hydrangea pink; guards clear; collar same as guards; center clear Bloom fades from hydrangea pink to milk white. Fragrance pleasant $\mathrm{X}$. Blooming time mid-season. Large size.

Description of plant-Habit of plant medium erect, medium tall, medium compact. Growth medium strong, healthy. Stem medium long, medium strong, reddish green. Blooming habit medium. Buds single, healthy. Foliage medium furnished, light green, medium size; veins reddish green.

Commercial a'aluc-For cut bloom medium; landscape value medium. Varioty as a whole medium.

Species - P. albiflora.

\section{SUPREME.}

Donated by Hollis.

Originated by Hollis, 1907 .

Description of bloom - Type of bloom rose. Form of bloom globular, medium compact. Not differentiated. Entirely transformed. Color (total effect) 3 (154) violet rose; guards slightly flecked; collar same as guards; center clear; uniform color throughout; secondary staminodes present. Fragrance unpleasant X. Blooming time very late. Large size.

Description of plant - Habit of plant medium erect, medium tall, compact. Grouth strong and healthy Stem medium long, very strong, green. Blooming habit 
medium. Buds borne in clusters, healthy. Foliage medium furnished, medium green, medium size; veins green.

Commercial value - For cut bloom medium; landscape value medium. Variety as a whole medium.

\section{SWEET HOME.}

Species - P. albiflora.

Originated by Hollis.

Donated by Hollis.

Descripion of bloom - Type of bloom rose. Form of bloom flat, loose. Not differentiated. Entirely transformed. Color (total effect) I (I54) violet rose; guards clear; collar same as guards; center clear; uniform color throughout; secondary staminodes present. Bloom fades quickly. Fragrance pleasant X. Blooming time late. Size medium to large.

Description of plant-Habit of plant medium erect to drooping, tall, medium compact. Growth strong and healthy. Stem long, medium strong, reddish green. Blooming habit medium. Buds borne in clusters, healthy. Foliage medium furnished, light green, medium size; veins green.

Commercial value - For cut bloom medium; landscape value medium. Variety as a whole medium.

\section{THÉR'ESE.}

Specics - P. albiflora.

Originated by Dessert, 1904 .

Donated by Cottage Gardens Company.

Description of bloom - Type of bloom rose. Form of bloom flat, medium cum. pact. Not differentiated. Entircly transformed. Color (total effect) violet rose 2 (I54); guards slightly splashed with crimson; collar same as guards; center clear, fading lilac white. Fragrance pleasant XX. Blooming time mid-season. Very large size.

Description of plant - Habit of plant erect, medium tall, compact. Growth strong and healthy. Stem medium long, strong, reddish green. Blooming habit medium. Buds borne in clusters, healthy. Foliage well furnished, dark green, medium size; veins red.

Commercial value - For cut bloom good; landscape value good. Variety is'a whole extra good.

Remarks-One of the most beautiful varieties in color and form.-A.P. $S$. and B. H. F.

\section{Red}

\section{ANDRÉ LAURIES.}

Specics - P. albiflora.

Donated by Farr.

Description of bloom - Type of bloom rose. Form of bloom globular, very compact. Not differentiated. Transformed. Color (total effect) dark tyrian rose 3 (I55); guards occasionally splashed with green; collar same as guards; center splashed with white; secondary staminodes absent. Very dense compact blnom, shading deeper in center, with red reflex. Fragrance absent. Blooming time very late. Very large size.

Description of plant-Erect, medium tall, compact. Growth strong, healthy. Stem medium to long, very strong, reddish green. Blooming habit very free. Buds borne in clusters, healthy. Foliage well furnished, dark green, medium size; veins green. 
Commercial valuc - For cut bloom extra good; landscape value good. Variety as a whole extra good.

Remarks - Entirely distinct from the variety commonly sold under this name, which should be known as "Fragrans," see page 63 .

\section{EDWIN BOOTH.}

Species - P. albiflora.

Originated by Hollis, 1905 .

Donated by Hollis.

Description of bloom - Type of bloom rose. Form of bloom globular, medium compact. Not entirely differentiated. Entirely transformed. Color 4 (I55) tyrian rose; guards clear; center clear, uniform color; secondary staminodes present. Fragrance pleasant X. Blooming time late. Small size.

Description of plant-Habit of plant medium erect; medium tall, compact. Growth strong, diseased. Stem medium long, medium strong," red. Blooming habit medium to shy. Buds borne in clusters, blight. Foliage medium furnished, dark grcen, fine; veins reddish green.

Commercial value - For cut bloom poor; landscape value poor. Variety as a whole poor.

Spccies - P. albiflora.

\section{GOLIATH.}

Donated by Farr.

Description of bloom - Type of bloom rose. Form of bloom globular, compact. Not differentiated. Entirely transformed. Color (total effect) I (I55) tyrian rose; guards clear; collar same as guards; center clear. Bloom has slight silver tip. Fragrance pleasant XX. Blooming time mid-season. Size very large.

Description of plant - Habit of plant erect, tall, compact. Growth strong and healthy. Stem long, strong, reddish green. Blooming habit free. Buds borne in clusters, healthy. Foliage well furnished, medium green, medium size; veins reddish green.

Commercial value - For cut bloom good; landscape value good. Variety as a whole good.

\section{LIBERTY.}

Species - P. albiflora.

Originated by Hollis, I905.

Donuted by Hollis.

Description of bloom - Type of bloom rose. Form of bloom globular, compact. Not differentiated. Entirely transformed. Color (total effect) 4 (I82) magenta; guards flecked with green; center clear; uniform color; secondary staminodes present. Bloom fades silvery. Fragrance pleasant X. Blooming time mid-season. Medium size to small.

Description of plant - Habit of plant medium erect to drooping, medium height, medium compact. Growth strong and healthy. Stem long, medium strong to weak, reddish green. Blooming habit medium. Buds borne in clusters, slight blight. Foliage medium furnished, medium green, medium size; veins reddish green.

Commercial value - For cut bloom medium; landscape value medium. Variety as a whole medium.

\section{LINNE.}

Species - P. albiflora.

Originated by Verdier, 1860.

Donated by Perennial Gardens. 
Description of bloom - Type of bloom rose. Form of bloom globular, compact. Slightly differentiated. Entirely transformed. Color (total effect) tyrian rose I (I55); guards slightly flecked; collar same color as guards; center flecked with crimson; secondary staminodes present. Compact, imbricated bloom. Similar to "Madame Lebon." Linear cream petals concealed throughout the bloom. Fragrance pleasant. X. Blooming time mid-season. Medium size.

- Description of plant - Habit of plant erect, medium tall, compact. Growth strong and healthy. Stem medium long, strong, reddish green. Blooming habit free. Buds borne in clusters, healthy. Foliage medium furnished, dark green, medium size; veins reddish green.

Commercial value - For cut bloom good; landscape value good. Variety as a whole good.

\section{RED CROSS.}

Species - P. albiflora.

Originated by Hollis, I904.

Donated by. Hollis.

Description of bloom - Type of bloom rose. Form of bloom flat, compact. Slightly differentiated. Entirely transformed. Color (total effect) 4 (I55) tyrian rose; guards clear; center clear; uniform color throughout; secondary staminodes present. Fragrance pleasant X. Blooming time late. Medium to small size.

Description of plant-Habit of plant erect, tall, compact. Growth strong and healthy. Stem long, medium strong to weak, reddish green. Blooming habit medium to free. Buds borne in clusters, healthy. Foliage poorly furnished, dark green, fine; veins green.

Commercial value - For cut bloom poor; landscape value medium. Variety as a whole medium.

\section{TWENTIETH CENTURY.}

Species- P. albiflora.

Originated by Hollis.

Donated by Hollis.

Description of bloom-Type of bloom rose. Form of bloom flat, compact. Not differentiated. Entirely transformed. Color (total effect) 2 (I55) tyrian rose; guards streaked light; collar same as guards; center clear; uniform color throughout; secondary staminodes present. Fragrance unpleasant XX. Blooming time mid-season to late. Large size.

Description of plant-Habit of plant medium erect, very tall, medium compact. Growth strong and healthy. Stem very long, medium strong, reddish green. Blooming habit medium. Buds borne in clusters, healthy. Foliage poorly furnished, dark green, medium size; veins red.

Commercial zalue - For cut bloom medium; landscape value poor. Variety as a whole medium. 


\section{INDEX TO VARIETY DESCRIPTIONS}

Aberl. PAGE

Acanum . . .................. $278 \quad 268$

Achille.

.

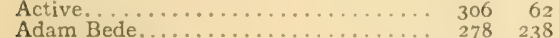

Adelaide E. Hollis................. $278 \quad 238$

Adele.

Admiral Dewey.................... $306 \quad 107$

Admiral Togo .................... $306 \quad 126$

Adolphe Rousseau.

Agnes Mary Keiway.

A ksarben...........

Alba Formosa

Alba Maxima....................... 306

Alba Plena.

Alba Sulfurea

Albatre.

Albert Crousse............... 306

Alexandre Dumas................ 278

Alexandriana................... 259

Alfred de Musset................ 278

Alice Crousse..................... 278

Alice de Julvécourt.............. 306

Alsace Lorraine. . . . . . . . . . . . . . . . . 306

Amalathea.................... 278

Amazone

Ambroise Verschaffelt.............. 278

American Beauty................ 306

André Lauries................... 278

Anemoneflora Alba.............. ${ }_{278}^{300}$

Anemoneflora Rubra................ 278

Anna.

Antietam ................. 306

Antoine Poiteau.............. 306

Armand Rousseau.............. 259

Armandine Mechin.............. 25

Arsène Meuret..................... 278

Arthemise. .................. 278

Asa Gray...................... 259

Aspasie .

Atrosanguinea ................ 278

Attraction................ 306

Auguste Gauthier. ............. 306

Auguste Lemonier. . . . . . . . . . . . . 306

Auguste Villaume ............... 306

Augustin d'Hour.................... ${ }_{278}$

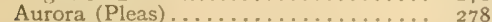

Aurora (Hollis) .................. 306

Aurore.................... 306

Austin Chamberlain............. 306

Autumnus................... 306

Avalanche................. 259

Baron James de Rothschild ......... 278

Baroness Schroeder................ 306

Battlefield...................... 306

Beauté Française.................... ${ }_{278}$

Beauté de Villecante............. 278

Beauty's Mask................ 306

Bélisaire......................... 306

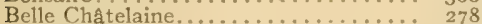

Belle Douaisienne............... 306

Belle of France............... 306

Belle Mauve.................. 306
BUZL, PAGE

................... $278-2+2$

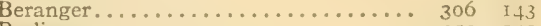

Berlioz.................... 259 IfI

Bernard de Palissy................ $\begin{array}{lll}278 & 278 & 290\end{array}$

Bicolor.................... 278 25I

Bismark.................... 306 I27

Blanche Cire................... 306.88

Blanche Dessert................ 306 I 20

Boule de Neige................ 306 IIt

Brennus..................... $306 \quad 6.3$

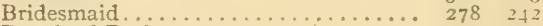

Bunch of Perfume.............. 278 29I

Burckii. Pam $306 \quad 106$

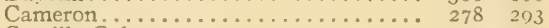

Camille Calot................... 259 IfI

Canari...................... 250 I3I

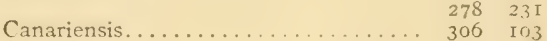

Candidissima................. 259 I3.

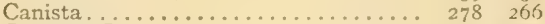

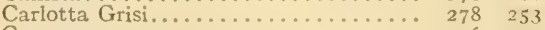

Carmen............................... 306 I20

Carnea Elegans (Calot)................ 278 262

Carnea Elegans (Guerin).......... 306 I.

Carnea Humei................... $278 \quad 287$

Carnea Striata.................. 306 I 33

Carnea Triumphans............. $278 \quad 252$

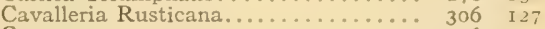

Ceres..................... 306 I07

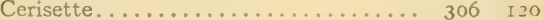

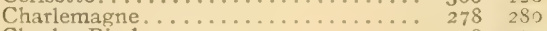

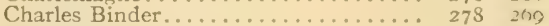

Charles de Belleyme............. 306 3t

Charles Gosselin.............. $278 \quad 2+1$

Charles Toché..................... 306 I2I

Charles Verdier................. 259 IfI

Charlotte Cushman............. 306 I 14

Cherita.................... 278 277

Chinensis Rubra................. $306 \quad 63$

Christine Ritcher............... $306 \quad \mathrm{I}+4$

Christopher Archard............. $306 \quad 96$

Chrysanthemiflora............... 259 I30

$\begin{array}{rr}278 & 232\end{array}$

Cinderella................. 306 \%

Claire Dubois...................... 306 It4

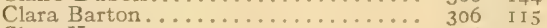

Clara Hersey. . . . . . . . . . . . . ... 306 I +4

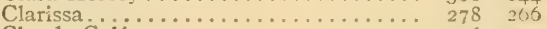

Claude Gelée..................... $306 \quad$ I33

Clementine Gillot................ 306 I

Clio...................... 259 I2s

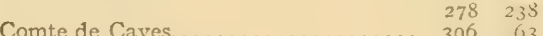

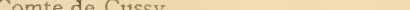

Comte de Diesbach....................... $278 \begin{array}{ll}278 & 255 \\ 269\end{array}$

Comte de Tussieu. .................. 306 of

Comte de Vanteuil.............. 306 Iri7

Comte d'Osmont................ 259 I3s

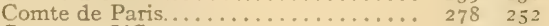

Comtesse O'Gorman............. $278 \quad 264$

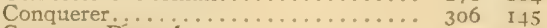

Constant Derred................... 250 IfI

Continental................. $306 \quad 85$

Coquelin.................... $306 \quad 127$

Countess of Warwick............... $306 \quad 69$

Coupe d'Hebe.................... $306 \quad 97$ 
BULL. PAGE

Couronne d'Or.

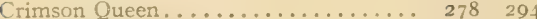

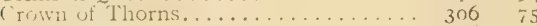

Curiosity.................... $306 \quad 79$

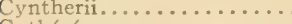

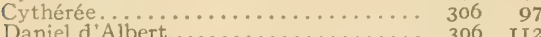

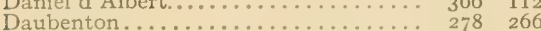

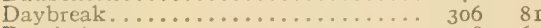

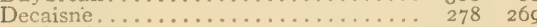

De Candolle...................... 259 I4

De Jussieu...................... . . 278238

Delachei..................... $259 \quad 135$

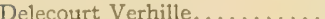

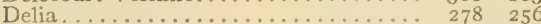

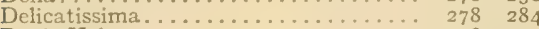

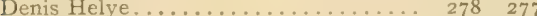

Departing Sun................... $306 \quad 108$

Descrites................... $306 \quad 85$

Diamond

Dorchester.

Dorothy

Dorothy E. Kibby.

Dr. Bretonneau (Guerin)

Dr. Bretonneau (Verdier)

Dr. Caillot

Dr. Edgar Pleas.........

Duc de Cazes.

Duc de Wellington.

Duchesse de Nemours.

Duchesse d'Orleans.

Duguesclin

Duke of Clarence.

Duke of Devonshire.

Early Rose

Eastern Beauty.

Eimond About.

Edmond Lebon.

Edouard André.

Edulis

Edulis Aiba.

Edulis Fragrans.

Edulis Odorata.

Edulis Superba.

Edwin Booth

Edwin Forrest.

E. G. Hill.

Elegans Superbissima.

Elie Chevalier

Ella Christine Kelway

Emile Lemoine. .

Emily. .

Emma.

Emmchen

Empereur Nicolas.

Emperar William

Enchantment.

Enchantresse....

Etendard du Grand Homme.

Etienne Denis.

Etienne Mechin.

Etta.

Eugene Bigot.

Eugène Reignoux...................

Eugène Verdier.

Eugénie Verdier.

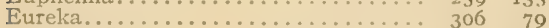

Evening Glow. . . . . . . . . . . . . . . . . . . . 306 . 306 . 81

Exquisite.................... $278 \quad 237$

Fairy Queen.................. $306 \quad 0.3$

Faust....................... $278 \quad 247$

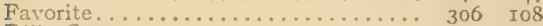

Félix Crousse.................. 259 I42

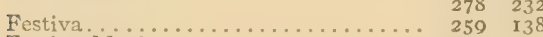

Festiva Maxima................... 259 138

Flag of Truce..................................... 306

Flag of War................. 306 7I
BULL. PAGE

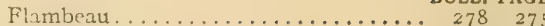

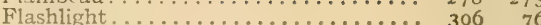

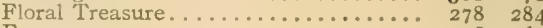

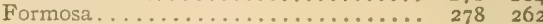

Formosa Alba.................... 259 I38

Formosa Rosea.................... $278 \begin{array}{rr}278 & 248 \\ 257\end{array}$

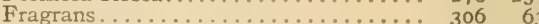

Fragrantissima.................. $306 \quad 64$

François Ist. . . . . . . . . . . . . . . . $259 \quad \mathbf{1 3 2}$

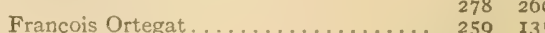

Frank Bramley.................. 306 . 72

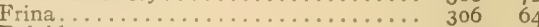

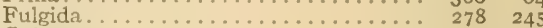

Galene......................... $306 \quad 64$

General Bedeau.................. 306 108

Général Bertrand............... 259142

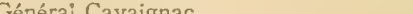

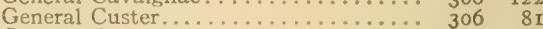

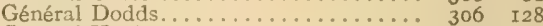

General Hooker................. 306 I 28

General Lawton................ 250 I36

George Hollis... . . . . . . . . . . . . . . . 306 I4

George Washington............... $306 \quad$ I 20

Georgiana Shaylor.............................. 306 I22

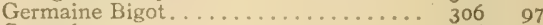

Gettysburg.................. 306 IOI

Gigantea...................... 306 . 64

Globosa.................................... $278 \quad 286$

Gloire de Charles Gombault............ $278 \quad 252$

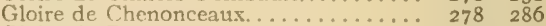

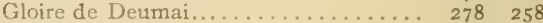

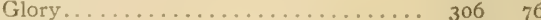

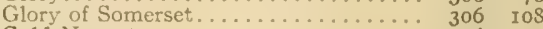

Gold Nugget.................... $306 \quad 79$

Golden Harvest. . . . . . . . . . . . . 27826.

Golden Wedding.............. $306 \quad 77$

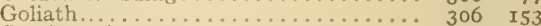

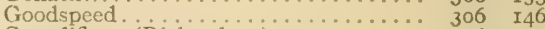

Grandiflora (Richardson)........... 306 I34

Grandiflora Alba Laciniata............ $278 \quad 248$

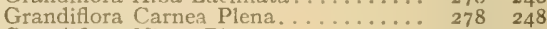

Grandiflora Nivea Plena............ 278248

Grandiflora Rosea................ $259 \quad 139$

Grandifiora Rubra................... $278 \quad 294$

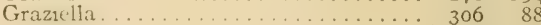

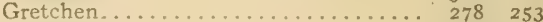

Grizzel Muir................... 306 I04

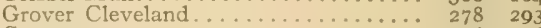

Gypsy....................... $3067 . \ldots \ldots$

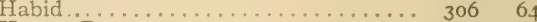

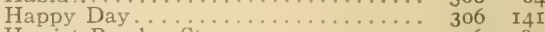

Harriet Beecher Stowe................... $306 \quad \begin{aligned} & 306 \\ & 82\end{aligned}$

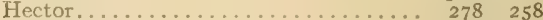

Henri Laurent. . . . . . . . . . . . . . . . . . . . . . . . . 350 I42

Henri Murger................... 306 I46

Henry Demay................. 278260

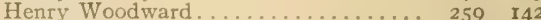

Hercules.................... 306 I09

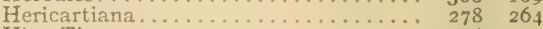

Hity Tity . . . . . . . . . . . . . . . $306 \quad 74$

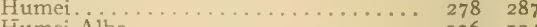

Humei Alba..................... $306 \quad 134$

Innocence. . . . . . . . . . . . . . . . $306 \quad 74$

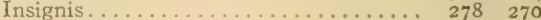

Intermedia. . . . . . . . . . . . . . . 259 I29

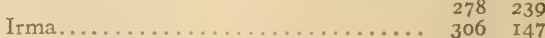

Isabella Karlitzky (synonym)........ $306 \quad 64$

Isabelle Karlitsky.................. $259 \quad$ I42

James Blanc.................... 306 I . 23

James Kelway................... 306 II5

Jeanne d'Arc................... 259 I3I

Jenny Lind . . . . . . . . . . . . . . . . . $\begin{array}{rr}278 & 278 \\ 267\end{array}$

Tessie K. Crosby .................. 306 . 147

John Hancook.................... $306 \quad 86$

Josephine....................... $278 \quad 238$

Jules Calot . . . . . . . . . . . . . . . . . . 259 I43

Juliette Dessert. . . . . . . . . . . . $\begin{array}{rr}278 & 283 \\ 278 & 294\end{array}$ 
Jupiter (Kelway)............... ${ }_{306}^{\text {BULL. PAGE }}$

Jupiter (Calot) .................. $259 \quad \begin{aligned} & 136 \\ & 259\end{aligned}$

Jussier....................... $278 \quad 245$

Karl Rosenfield. ................ $306 \quad$ I29

Kelway's-Queen................ $306 \quad$ 147

King Philip..................... $278 \quad 27 \mathrm{r}$

Labolas...................... $278 \quad 240$

L'Avenir..................... $306 \quad 80$

La Brune................... $278 \quad 276$

La Coquette.................. $259 \quad$ I 43

L'Eclatante. . . . . . . . . . . . . $\begin{array}{rr}278 & 232 \\ 278 & 270\end{array}$

L'Espérance....................... $278 \quad 247$

La Fée.

La Fiancée (Dessert).

La Fiancée (Lemoine)

La Fontaine

La France.

La Perle

La Rosière.

La Sublime.

La. Tendresse

La Tulipe.

La Vestale.

Lady Beresford.

Lady Brooke.

Lady Darmouth

Lady Leonora Bramwell

Lafayette. . .

Lamartine..............

Le Cygne.

Lee's Grandiflora....

Lemoine . . ...............................

Leucadia........................

Liberty . . . . . . . 306

Lilacina Superba................ 278

Linné...................... 306

Livingston....................... 278

Lord Roberts................... 306

Lost Treasure................. 306

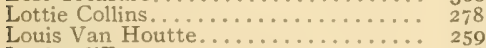

Louise d'Estrees.................. 278

Lotrise Renault....................... 278

Loveliness.................... 306

Lucie Malard.................. 306

Lucrece..................... 278

Lucy E. Hollis.................. 306

Lurana...................... 278

Lutea Plenissima................... 278

Lutetiana ................... 306

Madame Adrien Sénéclauze........... 306

Madame Auguste Dessert. .......... 306

Madame Barillet Deschamps......... 259

Madame Becquet. ....................... 306

Madame Benard. . ................ 278

Madame Bigot................. 306

Madame Bollet................... 278

Madame Bréon................. 278

Madame Calot............... 259

Madame Camille Bancel .............................. 278

Madame Carpentier.............. 306

Madame Chammie................ 278

Madame Chaumy .............. 278

Madame Costé................ 306

Madame Courant................ 306

Madame Crousse.

Madame de Bollemont. ....... 278

Madame de Galhau. .................. 278

Madame de Govin.................. 278

Madame de Guerle.................... 278

Madame d'Hour................ 278

Madame de Montijo.................. 278

Madame de Tréyéran.............. 306

Madame de Vatry................. 278

Madame de Vernéville............. 278

Madame Ducel.
Madame Émile Galle … Bull. PAGE

Madame Émile $\begin{array}{rrr}259 & 139 \\ 306 & 138\end{array}$

$\begin{array}{llll} & 278 & 273\end{array}$

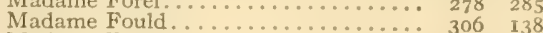

Madame Furtado............... $278 \quad 267$

Madame Geissler................. $259 \quad 143$

Madame Guyot. ........................... $278 \quad 234$

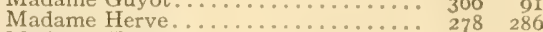

Madame Hutin ................... $278 \quad 275$

Madame Joanna Sallier.............. $306 \quad 82$

Madame Jules Calot................. $278 \quad 272$

Madame Jules Elie............... $300 \quad 08$

Madame Lebon................ $278 \quad 288$

Madame Lemoine................ $306 \quad 94$

Madame Lemoinier...................... 278 28

Madame Mechin............... $278 \quad 278$

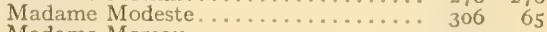

Madame Moreau................ 259 I43

Madame Moutot............... 306 I30

Madame Muyssart.............. $306 \quad 148$

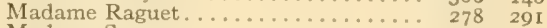

Madame Savreau.......................... 306 9r

Madame Schmidt.............. $278 \quad 259$

Madame Vilmorin.................. 306

Mademoiselle Desbuissons........................ 306 II6

Mademoiselle Léonie Calot............. $278 \quad 280$

Mademoiselle Marie Calot............. $306 \quad 139$

Mademoiselle Renée Dessert............ $259 \quad$ I43

Mademoiselle Rose Rendatler......... $306 \quad 95$

Mademoiselle Rousseau........... $259 \quad$ I34

Mademoiselle Vaillant. . . . ...... $278 \quad 273$

Maiden's Blush ......................... $306 \quad 278$ 104

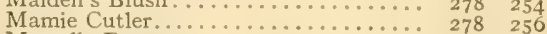

Marcelle Dessert

Marchioness of Lansdowne............. $306 \quad \begin{array}{r}306 \\ 149\end{array}$

Maréchal MacMahon............... 278 271

Maréchal Vaillant.................... $278 \quad 293$

Marguerite Gérard............. $259 \quad 134$

Marie...................... $278 \quad 235$

Marie Crousse....................... 306 . 306 II0

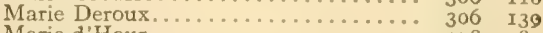

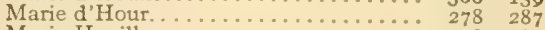

Marie Houillon.................. $278 \quad 287$

Marie Jacquin.................. $259 \quad 134$

Marie Lemoine................... $278 \quad 235$

Marie Louise.................. $278 \quad 289$

Marie Stuart (Calot)............. $278 \quad 255$

Marie Stuart (synonym)............ $306 \quad 65$

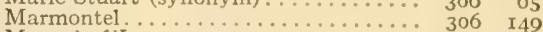

Marquis d'Lory .................. $306 \quad \begin{aligned} & \\ & 445\end{aligned}$

Marquis Ito ................ $306 \quad 65$

Mary A. Livermore................ $306 \quad \begin{aligned} & 306 \\ & 139\end{aligned}$

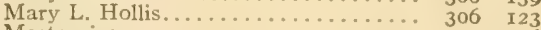

Masterpiece.................... $259 \quad 136$

Mathilde De Roseneck............ $259 \quad 144$

Mathilde Mechin................ $259 \quad 140$

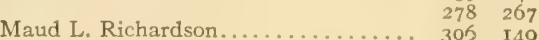

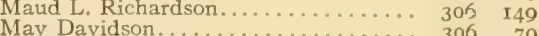

Meadowvale.................... 306 rio

Meissonier............................... 306 278

Melanie Henry.................. $278 \quad 286$

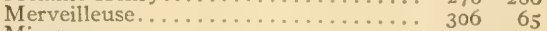

Microcarpa..................... $259 \quad 129$

Mikado......................... $259 \quad 130$

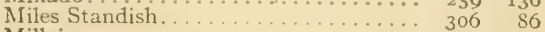

Millais................... $306 \quad 72$

Milton Hill .................. 306 I.49

Miss Brice.................... $306{ }_{306} \begin{array}{r} \\ 4\end{array}$

Miss Salway.................... $306 \quad 92$

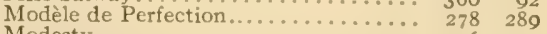

Modesty..................... $3066^{289}$

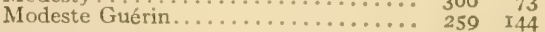

Monsieur Andre.............................. $278 \quad 235$

Monsieur Barral................... 278 25I 
Monsieur Bastien Le Page.

Monsieur Boucharlat âiné. .

Monsieur Charles Leveque.

Monsieur Chevreul.

Monsieur de Villeneuve...

Monsieur Doffrey

Monsieur Dupont.

Monsieur Hippolyte Delille.

Monsieur Jules Elie.

Monsieur Marsaux.

Monsieur Martin Cahuzac.

Monsieur Paillet.

Monsieur Paul du Ribert.

Monsieur Rousselon.

Mont Blanc

Morning Star.

Mountebank.

Mr. Manning

Mrs. Gwyn-Lewis

Mrs. John Smythe Fogg.

Mrs. Lowe.

Mrs. Sagute.

Myrtle.

$\mathrm{Ne}$ Plus Uitra.....

Nell Gwynn

Neptune.

Nico.

Nigricans.

Nivalis.

Nivea Plenissima.

Nobilissima

Noemie Demay.

Nomirata.

Octave Demay.

Pallas.

Pallasi

Papaveriflora.

Papilionacea.

Paradise.

Paradoxa...

Pearl.

Peregrina.

Perfection (Richardson).

Perfection (synonym)

Peter Pan

Petite Renée.

Philomèle

Phoenica Variegata

Phrynnée.

Pierre Dessert.

Picre Reignoux.

Pizano

Plena Variegata

Plenissima Rosea Superba.

Plutarch.

Portia .................... 306

Pottsi..............

Prairie Splendor................. 306

President de Montzey............... 259

President Wilder................ 306

Prince Alert

Prince d'Salm Dyck ................ 278

Prince Imperial................. 278

Princess Beatrice.................. 278

Princess Ellen.................. 278

Princess Galitzin.............. 278

Princess Maud.................. 278

Princess May..................... 306

Princesse Nicolas Bibesco ............. 306

Princess of Wales................ 306

Prolifera.

Prolifera Tricolor.................... 278

Pulcherrima.................. 278

Purpurea Superba................. 306
27. PAGE

$306 \quad 65$

I 40

284

$26 I$

665

I34

$78 \quad 233$

66 I50

III

277

$\begin{array}{ll}129 \\ 78 & 239\end{array}$

$\begin{array}{ll}78 & 276\end{array}$

258

272

\begin{tabular}{ll}
855 \\
\hline
\end{tabular}

$6 \quad 140$

$\begin{array}{rr}78 \\ 78 & 240\end{array}$

$\begin{array}{ll}8 & 240 \\ 8 & 278\end{array}$

I30

906
268

$306 \quad 65$

0698

82

65

\begin{tabular}{l}
92 \\
06 \\
\hline
\end{tabular}

130

$8 \quad 254$

I 40

I05

$6 \quad$ I23

I44

233

290

I 37

243

I 29

249

66

I 40

130

260

66

工 20

140

66

I 24

242

254

66

277

I30

258

66

I 40

268

245

III

250

I 24

I 44

92

77

265

250

259

265

263

95

99
66

254

268

102
BULL, PAGE

Queen Emma.

Queen Esther................. $306 \quad 66$

Queen of the Pinks............... $278 \quad 275$

Queen's Perfection............... $278 \quad 250$

Queen Victoria (Kelway).......... 306

Queen Victoria (synonym).......... $306 \quad 66$

Raphael..................... 306 I3I

Rare Brocade. . . . . . . . . . . . . . . $306 \quad 105$

Red Cross................... $306 \quad 154$

Red Jacket.................. 278295

Reevesiana.................. 306 67

Reine des Roses................ $278 \quad 265$

Reine Hortense . . . . . . . . . . . $306 \quad$ I24

Reine Victoria................ 306 I05

René Potard................. 259 I3I

Rosa Barry... . . . . . . . . . . . . . . $306 \quad 278$

Rosa Bonheur................. 306 I50

Rosa Lilacina... . . . . . . . . . . . . . $278 \quad 259$

Rosamond................. $306 \quad 67$

Rose Quintal. . . . . . . . . . . ... $278 \quad 291$

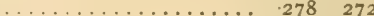

Rosea Elegans.................. 306 III

Rosea Magna................. $306 \quad 80$

Rosea Plenissima............... $306 \quad 67$

Rosea Plenissima Superba......... $306 \quad 67$

Rosea Superba................. $306 \quad 67$

Rosetta. . . . . . . . . . . . . . $306 \quad 67$

Rosilita....................... 306 III

Rossini.................... 306 I3I

Rosy Gem..................... $259 \quad 130$

Rubens. $\ldots . \ldots . \ldots 278$

Rubicunda.

Rubra................... $259 \quad 133$

Rubra Superba................ $278 \quad 295$

Rubra Triumphans.............. $306 \quad 87$

Ruy Blas.................. 306 I25

Sabina...................... 306 106

Sailet.................... 278 241

Sainfoin................... $278 \quad 259$

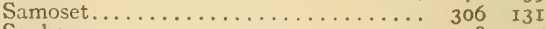

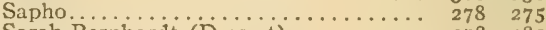

Sarah Bernhardt (Dessert)........... $278 \quad 282$

Sarah Bernhardt (Lemoine).......... $306 \quad 125$

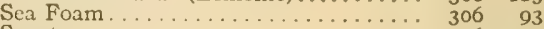

Senator.................... $306 \quad$ r32

Sidonie.................... $278 \quad 292$

Simonne Chevalier. . . . . . . . . . $306 \quad 99$

Snowball.................. 306 I40

Snow White..................... $306 \quad 67$

Solfatare.................. $278 \quad 250$

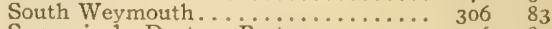

Souvenir du Docteur Bretonneau..... $306 \quad 87$

Souvenir de Gaspard Calot........... $278 \quad 283$

Souvenir de l'Exposition de Bordeaux. . 306 II3

Souvenir de 1'Exposition du Mans..... $278 \quad 245$

Souvenir de l'Exposition Universelle.... 259 I44

Speedwell

ard Bearer................ 306 II2

Stanley (Crousse) ................ 278202

Stanley (Kelway)................ $306 \quad 73$

Stewart's America................ 259 I40

$306 \quad 67$

Sully Prudhomme..................... 306 i5

Sunbeam................. $306 \quad 75$

Sunrise..................... $306 \quad 75$

Superba..................... $278 \quad 260$

Supreme................... 306 I5I

Sweet Home................ 306 I52

Sylvanus..................... $278 \quad 260$

Taglioni................... 30699

Teniers................... 259 r32

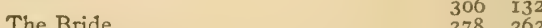

The King ..................

The Moor................... 259 129

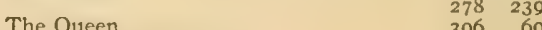

Theodore Rooseveit................ $306{ }_{30} 83$ 
Thérèse.

Thisbé .

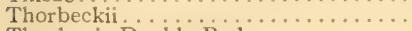

Thurlow's Double Red.

Tragedy.

Triomphe de l'Exposition de Lille....

Triomphe du Nord.

Triumphans Gandavensis

Triumphata .

Trojar

Twentieth Century

Umbellata Rosea.

Usona.

Van Dyrck.

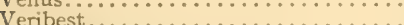

Vesta.

Vicomtesse de Belleval.

Victoire de l'Alma.
BULL. PAGE $306 \quad 152$ $306 \quad 68$ $\begin{array}{ll}278 & 292\end{array}$ $\begin{array}{ll}278 & 244\end{array}$ $306 \quad 68$ 306 II 3 $\begin{array}{ll}278 & 274\end{array}$ $259 \quad 133$ 259 I 4 I $306 \quad 68$ $306 \quad 94$ $306 \quad \mathbf{I} 25$ $306 \quad 154$ $\begin{array}{ll}306 & 154 \\ 278 & 202\end{array}$ $306 \quad 110$ $306 \quad 90$ $306 \quad 100$ $306 \quad 140$ $306 \quad 71$ $306 \quad 100$ $278 \quad 279$
RULL. PAGE

Victoire Lemon. . . . . . . . . . . . . . 278 253

Victoire Modeste................ 259, I32

Victor Durufle................. $306 \quad 68$

Victor Hugo................. $259 \quad 133$

Victor Lemoine. . . . . . . . . . . . $259 \quad 137$

Victor Paquet .................. 278200

Ville de Nancy .................. $259 \quad 144$

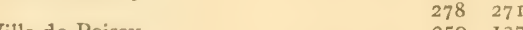

$\begin{array}{lll} & \end{array}$

Virginie.................... $259 \quad \mathbf{1 3 7}$

Virgo Maria.................. 259 I3I

Volcan.................... $259 \times 45$

$278 \quad 230$

Washington ................ 306 II

Water Lily ................... $278 \quad 242$

Welcome Guest............... $306 \quad 83$

White Lady . . . . . . . . . . . . . . $306 \quad 73$

Whitleyi................. 306 I00

Witch....................... $3066^{17}$

Youth...................... $306 \quad 78$ 






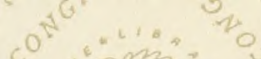

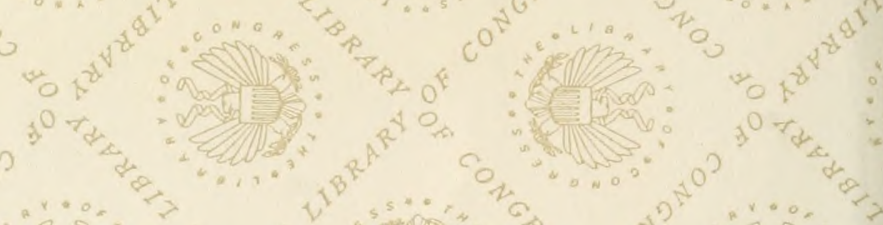

10

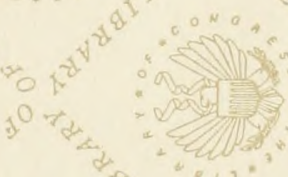
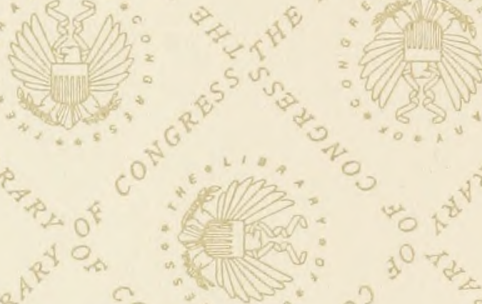

\section{tis}

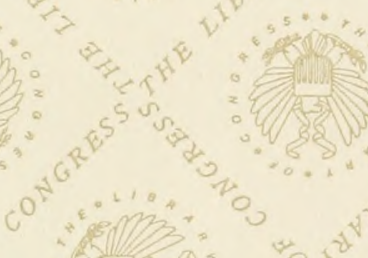

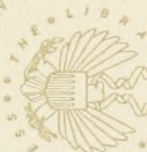

in

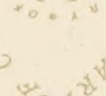

20

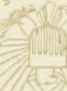

inn

(a)

(3)

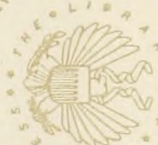

(n)
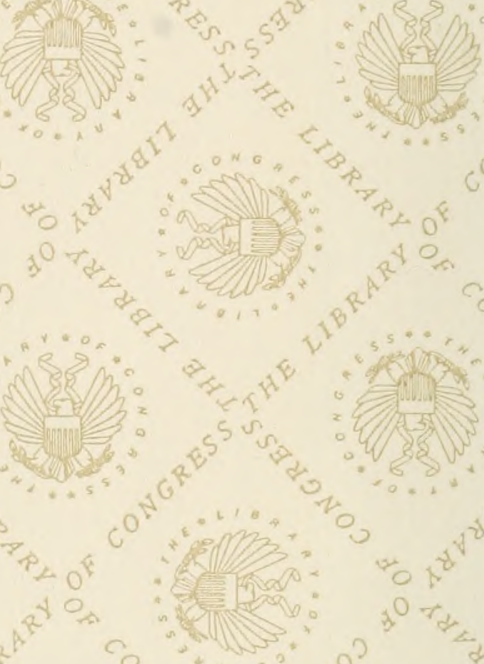

at 


\section{LIBRARY OF CONGRESS \\ ||||| || || || ||||||||||||||||||||||

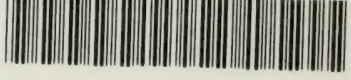 \\ 00009103648}

